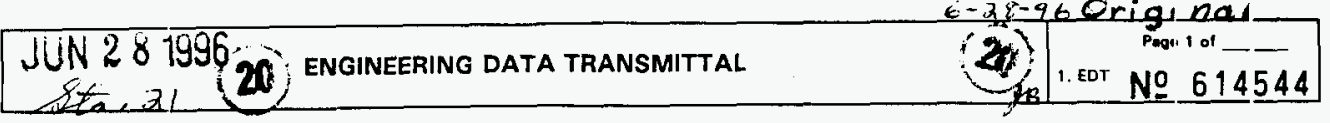

\begin{tabular}{|c|c|c|}
\hline $\begin{array}{l}\text { 2. To: (Receiving organization) } \\
\text { TWRS Characterization } \\
\text { Project }\end{array}$ & $\begin{array}{l}\text { 3. From: (Originating Organization) } \\
\text { TWRS SAR Engineering }\end{array}$ & $\begin{array}{l}\text { 4. Related EDT No.: } \\
\text { N/A }\end{array}$ \\
\hline $\begin{array}{l}\text { 5. Proj./Prog. /Bept.foiv.: } \\
\text { Light Duty Utility Arm }\end{array}$ & $\begin{array}{l}\text { 6. Cog. Engr.: } \\
\text { R. B. Conrad }\end{array}$ & $\begin{array}{r}\text { 7. Purchase order No.: } \\
N / A\end{array}$ \\
\hline \multirow{2}{*}{\multicolumn{2}{|c|}{$\begin{array}{l}\text { 8. originator Remerks: } \\
\text { The attached safety assessment describes hazards, accident } \\
\text { conditions, and necessary controls for the LDUA system when } \\
\text { it is deployed in tank } 241-T-106 \text { for a hot test. The safety } \\
\text { assessment is being generated in support of Unreviewed } \\
\text { Safety Question Evaluation \#TF-96-0171. }\end{array}$}} & $\begin{array}{l}\text { 9. Equip./Component No.: } \\
\qquad N / A\end{array}$ \\
\hline & & $\begin{array}{l}\text { 10. System/Bldg./Facility: } \\
\text { N/A }\end{array}$ \\
\hline \multirow{3}{*}{\multicolumn{2}{|c|}{ 11. Receiver Remerks: }} & $\begin{array}{l}\text { 12. Major Assm. Dwg. No.: } \\
N / A\end{array}$ \\
\hline & & $\begin{array}{l}\text { 13. Permit/Permit Applicstion No.: } \\
N / A\end{array}$ \\
\hline & & $\begin{array}{l}\text { 14. Required Response Date: } \\
\text { May 17, } 1996\end{array}$ \\
\hline
\end{tabular}

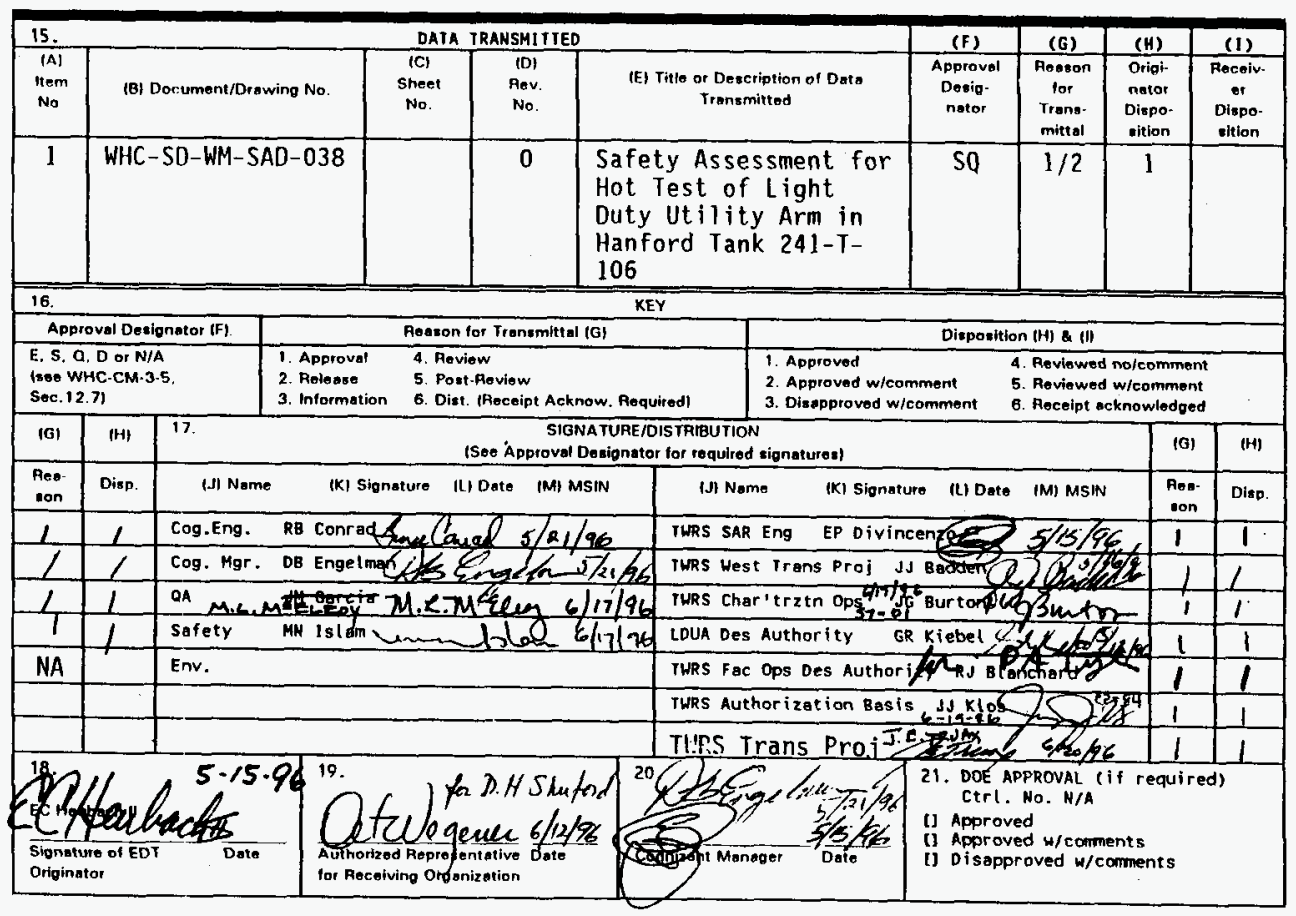

BD - 7400-172-2 (04/94) GEF097 


\section{Safety Assessment for Hot Test of Light Duty Utility Arm in Hanford Tank 241-T-106}

E. C. Heubach II

Westinghouse Hanford Company, Richland, WA 99352

U.S. Department of Energy Contract DE-AC06-87RL10930

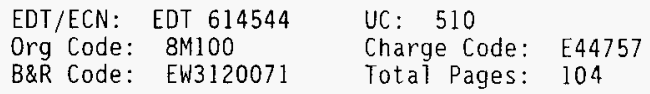

Key Words: Authorization Basis, Light Duty Utility Arm, safety assessment, safety basis, tank 24l-T-106, test, Unreviewed Safety Question Evaluation

Abstract: This safety assessment describes the proposed initial test of the Light Duty Utility Arm (LDUA), as it relates to the Tank Farms authorization basis and the previously analyzed safety basis. The LDUA will be tested in tank 24l-T-106. A companion document (not included as part of the safety assessment), USQ Evaluation TF-96-0171, concludes that the test of the LDUA in tank 241-T-106 is within the current Tank Farms authorization basis. The conclusions of the safety assessment show that the test can be performed safely, using presently implemented controls.

TRADEMARK OISCLAIMER. Reference herein to any specific commercial product, process, or service by trade name, trademark, manufacturer, or otherwise, does not necessarily constitute or imply its endorsement, recomnendation, or favoring by the United States Government or any agency thereof or its contractors or subeontractors.

Printed in the Unjted States of America. To obtain copies of this document, contact: WHC/BCS Document Control Services, P.O. Box 1970, Mailstop H6-08, Richland WA 99352, Phone (509) 372-2420; Fax (509) 376-4989.
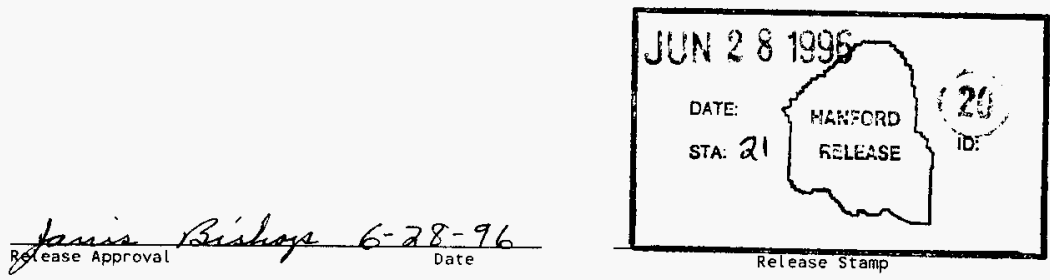

Approved for Public Release 
WHC-SD-WM-SAD-038 REV 0

SAFETY ASSESSMENT FOR THE HOT TEST

OF THE LIGHT DUTY UTILITY ARM IN HANFORD TANK 241-T-106

June 25, 1996 
WHC-SD-WM-SAD-038 REV 0

This page intentionally left blank. 


\section{EXECUTIVE SUMMARY}

The initial use of the Light Duty Utility Arm (LDUA) will be for the hot test in tank 241-T-106 at the Hanford Site. The LDUA is a mobile, remotely operated positioning system for use inside double- and single-shell tanks, primarily to perform inspection and surveillance. The LDUA System has the capability to reach locations within the tank that are not directly under the access risers. This capability has not previously been available to Tank Farm operations and is one of the primary reasons that the LDUA System was developed. The system is designed to operate safely in the hazardous (high radiation, flammable gasses, corrosive chemicals) environment of underground storage tanks at the Hanford Site and at other U.S. Department of Energy sites.

The hot test of the LDUA in tank 241-T-106, as defined in Engineering Task Plan (Howden et al. 1996), is considered to be within the current Tank Farms Authorization Basis. An Unreviewed Safety Question (USQ) Evaluation (TF-96-0171) has been performed to document that conclusion. The purpose of this safety assessment is to provide the supporting information needed to adequately answer the eight questions contained in the USQ Evaluation. The safety assessment is NOT an authorization basis document. The development of the safety assessment was preceded by a Hazards and Operability (HAZOP) study. The HAZOP is included as Appendix $A$ to this parent document.

The HAZOP was used to identify if new or unique hazards are posed by the test of the LDUA in tank 241-T-106 beyond those hazards already encountered, accepted, and adequately controlled by tank farm operating requirements and procedures. Potential accidents identified by the HAZOP study which might 
warrant IOSR/TSR level controls were examined further in the safety assessment to determine if they definitely represented a significant increase in the risk of operating at the Tank Farms. This determination was accomplished in two steps. First, a comparison was made of the potential accidents for the hot test of the LDUA to similar events analyzed for similar activities in the Tank Farms. Next, a comparison was made of the controls needed to properly manage the risk of the hot test of the LDUA to the existing controls needed to manage the risk for similar activities.

The results show that: (a) the risk associated with the hot test of the LDUA in tank 241-T-106 does not significantly increase the overall risk of operating the Tank Farms; and, (b) no new controls or unique application of existing controls need to be implemented for an acceptably safe test of the LDUA in 241-T-106.

Accident analyses that count as part the Authorization Basis for activities in 241-T-106 are limited to those contained in the SST Isolation Safety Analysis Report (WHC 1989a) and Stabilization of SSTs by Salt Well Pumping Safety Analysis Report (WHC 1989b). These two documents are the primary basis for demonstrating that the hot test of the LDUA in 241-T-106 is bounded by existing analyses.

Two additional safety analyses were used as analogues to assess the safety of the proposed test of the LDUA. The first analog is the push-mode and rotary-mode core sampling unit (Milliken et al 1995). This unit is similar to the LDUA in that both systems involve moving a heavy vehicle on to the top of a tank, connecting to a riser, and lowering into the tank an 
object, which, if not properly constrained, could damage either the riser or the interior of the tank. The second analog is the operation of the voidmeter in tank 241-SY-101 (LANL 1995). Both the voidmeter and the LDUA involve the use, inside of a tank, of an articulated arm, which if not properly configured prior to removal, could potentially damage the tank dome or the riser used for insertion.

All potentially serious accidents associated with the test of the LDUA in tank 24l-T-106 are in the category of mechanical damage to the tank. External tank damage could arise either from dome overload or from damage to a riser. Internal damage could arise either from natural forces events causing excessive movement of the Vertical Positioning Mast or from errors made while deploying the LDUA into the tank. The results of the safety assessment show that all of these events can be adequately controlled by conformance with: existing controls including dome loading and vehicular traffic restrictions on the design and operation of the LDUA and associated equipment; existing controls for Tank Farms hoisting and rigging activities; design features of the LDUA, such as redundant controls for arm movement; and, other existing operating requirements, such as inclement weather restrictions, that are generic to tank intrusive activities.

A secondary purpose of this safety assessment is to provide a starting point for subsequent assessments of future LDUA deployment in tanks other than 241-T-106. The HAZOP, for example, is applicable to all 177 DSTs and SSTs and includes hazards for tanks subject to flammable gas controls. It should be noted that tank 24l-T-106 is not now, and has never been, on any watchlist, including the Flammable Gas Watchlist. 
WHC-SD-WM-SAD-038 REV 0 


\section{TABLE OF CONTENTS}

1.0 SCOPE

1.1 BACKGROUND . . . . . . . . . . . . . . . . . . 1-1

1.2 PURPOSE . . . . . . . . . . . . . . . . . . . . . 1-1

1.3 SAFETY PHILOSOPHY . . . . . . . . . . . . . . . . . 1-3

1.4 APPLICABLE TANKS . . . . . . . . . . . . . . . . . 1-5

2.0 DESCRIPTION OF ACTION . . . . . . . . . . . . . 2-1

2.1 LIGHT DUTY UTILITY ARM SYSTEM DESCRIPTION . . . . . . . . $2-1$

2.2 LIGHT DUTY UTILITY ARM OPERATIONS . . . . . . . . . . . . . 2-4

2.2.1 Light Duty Utility Arm System Setup . . . . . . . 2-4

2.2.2 Light Duty Utility Arm System Operation....... 2-5

2.2.3 Light Duty Utility Arm System Disassembly . . . . 2-6

3.0 IDENTIFICATION OF HAZARDS ................. . . . . . . .

3.1 HAZARD AND OPERABILITY STUDY .............. . . . . . . . .

3.2 TANK $241-T-106$ HAZARD AND OPERABILITY STUDY . . . . . . . . 3-1

4.0 HAZARDS ANALYSIS . . . . . . . . . . . . . . . . . . 4-1

4.1 EVALUATION OF POSTULATED ACCIDENTS . . . . . . . . . . 4-3

4.1 .1 NODE 1 . . . . . . . . . . . . . . . 4 4-3

4.1 .2 NODE $2 \ldots . . . . . . . . . . . .44$

4.1 .3 NODE $3 \ldots \ldots . . . . . . . . . . .44-5$

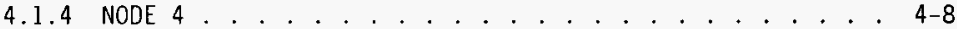

4.1 .5 NODE $5 . . . . . . . . . . . . . . .44-9$

4.1 .6 NODE 6 . . . . . . . . . . . . . . . . . 4-9

4.1 .7 NODE 7 . . . . . . . . . . . . . . . .

4.2 SCREENING OF POSTULATED ACCIDENTS ............... 4- . .

5.0 CONSEQUENCES OF ACCIDENTS . . . . . . . . . . . . . . . 5-1

5.1 LIGHT DUTY UTILITY ARM ACCIDENT RISK . . . . . . . 5-5

5.1.1 Release Calculation 1 (REL-1), Loss of Confinement Open Riser. . . . . . . . . . . . . 5-5

5.1.2 Release Calculation 2 (REL-2), Partial Dome Collapse . 5-7

5.1.3 Release Calculation 3 (REL-3), Rupture of

VPM Housing or TRIC . . . . . . . . . . . .

5.1.4 Release Calculation 4 (REL-4), Aerosol Leak at TRIC . 5-10

5.1.5 Release Calculation 5 (REL-5), Liquid Leak at

Decontamination Module......... . . 5-10

5.2 RISK ACCEPTANCE GUIDELINES . . . . . . . . . . . 5-12

5.2.1 Radiological Risk Acceptance Criteria . . . . . . . 5-12

5.2.2 Toxicological Risk Acceptance Guidelines..... . . 5-13

6.0 CONTROLS . . . . . . . . . . . . . . . . . . . . . . . . . . . . . . 6-1

6.1 BASIS FOR SELECTION ............ . . . . . . .

6.2 TANK 241-T-106 CONTROLS . . . . . . . . . . . . . . . 6-1

6.2.1 Generic Controls............... 6-1

6.2.2 Specific Controls . . . . . . . . . . . 6-1

6.3 DESCRIPTION OF SPECIAL EQUIPMENT REQUIREMENTS ........ . $6-2$

6.4 DESCRIPTION OF CONTROLS FOR PREVENTION AND MITIGATION . . . . . $6-2$ 
WHC-SD-WM-SAD-038 REV 0

\section{TABLE OF CONTENTS (Continued)}

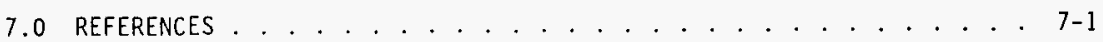
APPENDIX

A HAZOP STUDY . . . . . . . . . . . . . . . . . . . . . . A-i 


\section{LIST OF FIGURES}

1-1 Overview of Light Duty Utility Arm System . . . . . . . . . 1-2

1-2 Progressive Levels of Risk for Light Duty Utility Arm Operations. . . . . . . . . . . . . . . . 1-4

A-1 Light Duty Arm and Deployment System. . . . . . . . . . . . A-4

\section{LIST OF TABLES}

3-1 Tabulation of Tank 241-T-106 Events by Consequence Rank for Each Node . . . . . . . . . . . . . . . . . 3-2

4-1 Accidents Postulated for the Light Duty Utility Arm Operations at Tank 241-T-106............. . . 4-1

5-1 Estimated Frequencies and Consequences of Light Duty Utility Arm Accidents at Tank 241-T-106 . . . . . . . . . . . 5-2

5-2 Estimated Radiological Consequences of Bounding Accidents for Light Duty Utility Arm Operations at Tank 241-T-106 . . . . . . 5-11

5-3 Radiological Risk Guidelines. . . . . . . . . . . . . 5-12

5-4 Comparison of Radiological Consequences of Light Duty Utility Arm Operations at Tank 241-T-106 with Risk Acceptance Guidelines . . . . 5-13

5-5 Toxicological Risk Guidelines . . . . . . . . . . . . . . . 5-13

5-6 Comparison of Estimated Toxicological Consequences to Guidelines . . . . . . . . . . . . . . . 5-14 


\section{LIST OF TERMS}

$\begin{array}{ll}\text { ALARA } & \text { as low as reasonably achievable } \\ \text { ATIE } & \text { At-Tank Instrument Enclosure } \\ \text { CGM } & \text { Combustible gas meter } \\ \text { DOE } & \text { U.S. Department of Energy } \\ \text { DWSS } & \text { Decontamination Water Supply System } \\ \text { ERPG } & \text { Emergency Response Planning Guideline } \\ \text { FHE } & \text { fire hazards evaluation } \\ \text { HAZOP } & \text { hazard and operability study } \\ \text { HLW } & \text { high-level waste } \\ \text { HSRCM-1 } & \text { Hanford Site Radiation Control Manual } \\ \text { LDUA } & \text { Light Duty Utility Arm } \\ \text { LFL } & \text { lower flammability limit } \\ \text { MDS } & \text { Mobile Deployment System } \\ \text { NEC } & \text { National Electrical Code } \\ \text { NFPA } & \text { National Fire Protection Association } \\ \text { OAS } & \text { optical alignment Scope } \\ \text { OCC } & \text { Operations Control Center } \\ \text { OCT } & \text { Operations Control Trailer } \\ \text { OSD } & \text { Operating Specification Document } \\ \text { OSVS } & \text { Overview Stereo Video System } \\ \text { OVS } & \text { Overview Video System } \\ \text { PASS } & \text { Purge Air Supply System } \\ \text { PDS } & \text { Power Distribution Skid } \\ \text { PEL-TWA } & \text { Permissible Exposure Limit - Time-Weighted Average } \\ \text { PIM } & \text { Power Interface Module } \\ \text { RAG } & \text { risk acceptance guidelines } \\ \text { REL } & \text { release calculations } \\ \text { SCADAS } & \text { Supervisory Control and Data Acquisition System } \\ \text { SMP } & \text { Surface Moisture Probe } \\ \text { SST } & \text { single-shell tank } \\ \text { TIP } & \text { Tool Interface Plate } \\ \text { TRIC } & \text { Tank Riser Interface and Confinement } \\ \text { USQ } & \text { unreviewed safety question } \\ \text { VPM } & \text { Vertical Positioning Mast } \\ \text { WHC } & \text { Westinghouse Hanford Company } \\ & \end{array}$




\subsection{SCOPE}

\subsection{BACKGROUND}

The light duty utility arm (LDUA) Program was initiated in 1992 by the U.S. Department of Energy's (DOE) Office of Science and Technology, then known as the Office of Technology Development. The development was at the request of the Hanford Tank Waste Remediation System to provide a new capability to obtain information to support operations associated with underground storage tanks, and to aid in the remediation of the tanks at the Hanford Site and throughout the DOE complex.

Application of the LDUA at the Hanford Tank Farms is a key activity in the Hanford mission to remediate the high-level waste (HLW) tanks. The LDUA is a mobile, remotely operated positioning system for use inside the waste tanks, that will perform waste tank inspection and surveillance. Associated with the LDUA are several interfacing systems for operation of the arm. The LDUA system is described in Light Duty Utility Arm Baseline System Description, WHC-SD-TD-ER-005 (Kiebe1 1996). The LDUA System deploys a family of tools and sensors, called end effectors, into underground storage tanks by means of a robotic arm on the end of a telescoping mast, and collects and manages the data generated. Access to the tank is gained through existing risers. A Mobile Deployment System (MDS) transports the mast and arm between tanks and positions them over a $30.5-\mathrm{cm}$ (12-in.) tank riser for deployment. Ancillary subsystems support the main deployment equipment, performing such functions as maintaining confinement of the tank atmosphere; decontamination of mast, arm, and end effector; power distribution; and observation of in-tank operations. The LDUA System is operated from the remote Operations Control Trailer (OCT) located outside the perimeter fence of the Tank Farm, up to $275 \mathrm{~m}(900 \mathrm{ft}$ ) from the deployment vehicle (see Figure 1-1).

The LDUA System provides the capability to reach locations within the tank that are not directly under the access risers. This capability has not been available to Tank Farm operations (other than the voidmeter in tank 241-SY-101) before and is one of the primary reasons that the LDUA System was developed. The system is designed to operate safely in the hazardous (high radiation, flammable gasses, corrosive chemicals) environment of underground storage tanks at the Hanford Site as well as at other DOE sites. It is also designed to accept new end effectors and to adapt to new missions with little modification to the existing system.

\subsection{PURPOSE}

This safety assessment was prepared in compliance with Westinghouse Hanford Company (WHC) policy WP 5.6 "Safety Assessments," WHC-CM-6-32 Safety Analysis and Engineering Work Practices (WHC 1992). The purpose of this document is to supplement an unreviewed safety question (USQ) evaluation concerning the LDUA and to demonstrate that the LDUA can be operated safely. The safety assessment is NOT an authorization basis document. The operational controls that must be used to ensure safe operation are defined. The objective of this safety assessment is to review all safety-related aspects of LDUA operations at tank 241-T-106, and to document the results to show that 
Figure 1-1. Overview of Light Duty Utility Arm System.




the hot test of the LDUA in tank 241-T-106 is bounded by existing analyses.

Included in the assessment are the equipment design, safety features, and intended operation of all components that are part of the LDUA or are required for deployment and operation of the LDUA. Although future LDUA operations are intended for a 11 HLW tanks, this analysis is limited to the hot test in tank 24l-T-106.

It should be noted that tank 241-T-106 is not now, and has never been, on any Watchlist, including the Flammable Gas Watchlist.

\subsection{SAFETY PHILOSOPHY}

The principal safety criteria applicable to operation of the LDUA System at the Hanford Tank Farms are provided in DOE Orders, WHC Manuals, and Tank Farm documents and operating procedures. All LDUA systems and components were designed in compliance with these requirements.

The safety philosophy for LDUA operations is to employ a phased sequence of activities that progresses from lowest risk to highest risk as confidence and operational experience is gained in the use of the LDUA System in the Hanford tanks. The principal safety goal will be to maintain protection against the simultaneous occurrence of an ignition source (e.g., : spark) and a flammable atmosphere. This goal will be implemented by the combination of (1) the LDUA purge air system, designed for operation in flammable atmospheres, acting in conjunction with the main safety system for the LDUA, which can shut down electric energy to the arm when purge air is not functioning properly, and (2) the avoidance of activities with ignition potential when the tank atmosphere exceeds $25 \%$ of the lower flammability limit (LFL). Thus, when operations are undertaken in a tank such as tank 241-T-106, which does not require flammable gas controls, the criteria is satisfied and the risk is low. Operations in any other tank are beyond the scope of this document.

Future LDUA operations will be categorized by risk and will be undertaken in a sequence that begins with low risk activities and progresses to the next level only after success is demonstrated at the previous level. Figure 1-2 illustrates the progressive levels of risk.

Activities are categorized into risk levels in two ways, by tank atmosphere flammability and by potential for an ignition source. Lower risk operations are those that involve activities in tanks with a nonflammable atmosphere or involve activities that have very low or no ignition potential. Higher risk operations involve activities in tanks that are known to contain either flammable gas or waste capable of producing flammable gas. 
Figure 1-2. Progressive Levels of Risk for Light Duty Utility Arm Operations.




The risk increases if activities in these tanks involve unknown materials or materials with a significant ignition potential. Similarly, lower risk activities are those that are not waste intrusive or that involve handling only spark-resistant material. Higher risk operations include waste intrusive activities and the movement of unknown materials and potential spark generating materials inside the tanks. The risk increases further if operations are conducted in a tank that has an atmosphere at or above the LFL (a violation of the principal safety criteria).

Operations planned for tank 241-T-106 are performed with equipment designed and tested to meet the National Fire Protection Association (NFPA) 496 code requirements for purged enclosures in a flammable environment (Type $X$ and $Z$ purge modes) (NFPA 1993a). Equipment failures that could cause waste intrusive events during operation in tank 241-T-106 were postulated and evaluated during the hazard and operability study (HAZOP) and were judged not to have a significant safety impact. The only operations planned in tank 241-T-106 that will contact waste involve the use of the surface moisture probe (SMP) and the gripper. The SMP will be set on the top of the waste surface to measure surface moisture content. The SMP will be decontaminated as it is withdrawn from the tank. The gripper will not be used to disturb the waste (i.e., in motion under the waste) in Tank 241-T-106 without further evaluation and revision of the safety assessment.

Testing that does not involve potential ignition activities in tanks that are not considered flammable gas tanks constitute the lowest risk (Risk Level I) and will be undertaken first in tank 241-T-106. Testing in tanks that contain potentially flammable waste (e.g., flammable gas Watchlist tanks) will be deferred to future deployments and may require special controls.

Activities in tank 24l-T-106 that do not involve the potential to generate sparks include remote viewing with the high resolution stereo video system, remote viewing with the overview video system (OVS), remote viewing with the overview stereo video system (OSVS), and measurements with the SMP. Tank operations that involve the potential to produce sparks include activities that contact in-tank components that may not be made of sparkresistant materials, such as gripper movement of solid objects.

\subsection{APPLICABLE TANKS}

This safety assessment is limited to the hot test of the LDUA in tank 241-T--106. The tank is not on any of the four Watchlists and is considered interim stabilized. Little waste remains in tank 241-T-106; current volume of waste is $79 \mathrm{~kL}(21,000 \mathrm{gal})$ (Jo 1996). The hot test will increase the overall confidence level in LDUA procedures, equipment functionality, and personnel training without the risks associated with operations in a tank with flammable gas controls. 
WHC-SD-WM-SAD-038 REV O

This page intentionally left blank. 


\subsection{DESCRIPTION OF ACTION}

\subsection{LIGHT DUTY UTILITY ARM SYSTEM DESCRIPTION}

The LDUA is shown in Figure $1-1$ in its deployed and operating configuration inside a typical underground tank at the Hanford Tank farms. Associated with the LDUA are several interfacing systems for operation of the arm. The LDUA system is described in detail in Kiebel (1996).

The Baseline LDUA System is organized into a hierarchy of major equipment systems and subsystems listed below. The hierarchical numbering scheme presented in the LDUA Baseline System Description is listed below. The Subsystems that are not part of tank 241-T-106 deployment are identified. Three additional systems (System 5140,6460, and 6410) not shown in the Baseline Description will be deployed as part of the tank 241-T-106 operations. These three systems are included in the list, and were part of the HAZOP and this safety assessment.

2000 Arm/Deployment System

2100 Mobile Deployment System

2200 Vertical Positioning Mast (VPM)

2300 Light Duty Utility Arm

2310 Tool Interface Plate (TIP)

2400 LDUA Subsystem Controller

3000 Tank Riser Interface and Confinement (TRIC) System

3150 Confinement Enclosure

3160 Mast housing adaptor (flexible coupling TRIC to VPM)

3300 Decontamination System

3340 Decontamination Water Supply System (DWSS)

3350 Decon Water Module

3360 Riser Isolation Valve

3500 Miscellaneous TRIC Instrumentation and Control

3520 Rad Monitor System

3600 TRIC Accessories

3660 Manual End Effector Exchange System

4000 Operations Control Center (OCC)

4100 Operations Control Trailer (OCT)

4200 Supervisory Control and Data Acquisition System (SCADAS)

4300 At-Tank Instrument Enclosure (ATIE)

4400 Control Network

5000 Utilities

5100 Electrical Systems

5110 Temporary Utility Power

5120 Portable Generator

5130 Power Distribution Skid (POS)

5140 Power Interface Module (PIM)

5200 Compressed Gas Systems

5230 Purge Air Supply System (PASS)

5400 Miscellaneous Gas Systems

5410 Purge Gas Supply $* \star$ Not used at T-106** 
6000

End Effectors

6100 Tank Mapping Systems

6110 Topographical Mapping System

$\star *$ Not used at $T-106 * *$

6200 Remote Viewing Systems

**Not used at T-106**

6210 Overview Video System

6220 Overview Stereo Video System

6230 High Resolution Stereo Video System

$\star *$ Not used at T-106**

6240 Still/Stereo Photo System $* \star$ Not used at T-106**

6250 Optical Alignment Scope

6460 Surface Moisture Probe

6410 Gripper

8000 0ther Equipment

8100 Riser Characterization Equipment

8200 Operations Overview Video System 1996.

Following is a summary description of the LDUA system, taken from Kiebel

The LDUA (subsystem 2300) and VPM (2200) tubes are inserted into the tank through a riser prequalified for LDUA interfacing. The arm (Spar equipment) has a maximum diameter of $27 \mathrm{~cm}$ (10.5 in.) to allow insertion through typical $30-\mathrm{cm}$ (12-in.) risers, and the interface to the riser will be via the TRIC Subsystem (3000). The MDS (2100) is used to erect the LDUA and VPM from their horizontal, stowed positions into a vertical or near-vertical deployed position so that they are aligned with the riser to be used for insertion. The LDUA and VPM tubes are enclosed and supported inside a truss frame covered with panels that protects them during transport and handling. The VPM housing provides a contamination control boundary during operations. The control subsystem performs monitoring and control of the system and enables safe, responsive, and coordinated operation of the subsystems and is operated from the Control Console in the OCT $(4100)$ at a remote location up to $270 \mathrm{~m}$ $(900 \mathrm{ft})$ from the ATIE (4300) and MDS. The control subsystem al so provides the interface to the user's graphics-based teleoperator control station. The user's end effectors are attached to the LDUA by means of a TIP (2310) and this mating/demating operation is accomplished manually using end effector exchanger equipment at the TRIC. Jumpers in the ATIE are used to connect the appropriate power signal and fluid utilities to the selected end effector. The command and control data for the system is electrically isolated from the remote control station via digital fiber optic links to the ATIE.

The use of digital data links provides increased immunity from the electrical node and increases overall failure tolerance of the system. The system includes the necessary multiplexer/demultiplexer and conversion circuits in the ATIE and the OCT.

The VPM includes a two-element telescopic mast that extends from an airtight container (VPM housing) to provide the required vertical positioning of the LDUA. The VPM housing also encloses the LDUA when the mast is retracted. The VPM housing is sealed to the TRIC during operation and maintains a contamination control boundary. The two cylindrical tubes (inner and outer tubes) are made of CRES 304L stainiess steel for enhanced stiffness and resistance to chemical attack. The LDUA arm attaches to the lower end of the inner tube; both the inner tube and the manipulator retract inside the 
outer tube for storage inside the VPM housing. When the LDUA and the mast are retracted, the VPM housing is sealed by a $36-\mathrm{cm}(14-i n$.$) valve for confinement$ and transportation of the potentially contaminated hardware. Both of the VPM tubes are raised and lowered by redundant cables. Each cable is sized to its load using a 5:1 load safety factor.

The LDUA is a seven-jointed positioning system with an off-axis reach of $4 \mathrm{~m}(13.5 \mathrm{ft})$ and a payload capacity of $34 \mathrm{~kg}(75 \mathrm{lb})$. The manipulator is made from 17-4PH stainless steel, and is attached to the inner tube of the VPM telescopic mast. The seven joints provide kinematic redundancy to enable the manipulator to maneuver around obstructions while eliminating or minimizing constraints on the end-point motion. The enhanced obstacle avoidance capability is expected to be particularly useful in the Hanford tanks that contain large numbers of risers and previously deployed hardware.

Five of the seven joints need to generate large torques due to the arm and payload weight. These five joints are hydraulically actuated to provide compact packaging and low power dissipation for the required torque and the size 1 imitations. All hydraulic joints use redundant actuators and controls to reduce failure modes. All LDUA arm and tube joints use position resolvers. The two joints that do not generate large sustained torques (shoulder yaw and wrist roll) are electrically powered because their angle of travel is wide. These electrically powered joints provide simple, effective low-speed control. In the event of a power loss or equipment failure the LDUA can assume a 1 imp condition in which the joints are backdriven by the arm deadweight until the arm hangs vertically downward to facilitate its recovery from the tank.

During in-tank operation, silicon rubber sleeves will cover the moving parts of all hydraulic joints.

The MDS comprises a special purpose erection and alignment assembly for the VPM mounted on a standard truck chassis. The special purpose assembly contains an $X-Y$ roll table for longitudinal, lateral, and roll alignment of the VPM to the TRIC and riser. A telescoping hydraulic cylinder attached to the $X-Y$ roll table rotates the VPM about a trunnion mount at its lower end to elevate it to the required position. The hydraulic power unit and the subsystem controller are mounted on the MDS. Outriggers are used to increase stiffness and stability of the system when deployed.

The subsystem controller (2400) is comprised of the control logic, software, drivers, and signal processing for control of the LDUA, VPM, and MDS and is located on the MDS. The control algorithms of the LDUA provide for the 6 degrees-of-freedom (X, Y, Z, roll, pitch, yaw) at the end effector, and kinematic redundancy management. The subsystem controller is equipped with a control pendant so that the system can be operated locally with limited functionality when not controlled from the remote console subsystem. Point of control (a safety feature) must be given up by the operator at one location before commands are accepted from the other location. This feature ensures that only one location is in control.

The LDUA is designed to be operated remotely by two operators in the OCT using computer workstations. The LDUA operator directs the deployment subsystems, and the end effector operator directs the end effectors and collects data. 
The LDUA console subsystem provides remote displays and controls to operate the system and is located in the OCT up to $270 \mathrm{~m}$ (900 ft) from the rest of the MDS. The LDUA console subsystem includes a workstation, hand controller for operating the arm, and discrete controls (switches). The operations control workstation provides a 3-D animated graphic display for viewing the operation of the VPM and the LDUA. The operator may preview LDUA motion in simulation using any of the motion control modes that the system provides. If the previewed motion is acceptable and collision-free, the operator may command the LDUA system to execute the motion.

The data acquisition workstation provides the primary interface for the operating end effectors and collecting data. It provides a single point from which data can be acquired, processed, and stored.

There are many video cameras in the LDUA system. The video display and recording subsystem provides monitors and video recorders to display and record video information from these sources. All aspects of video switching, recording, annotation, and display are controlled by the SCADAS workstation. Various cables are routed above ground to interconnect the subsystems when the LDUA system is deployed at a tank.

The interface signal conditioning electronics and electrical isolation relays for the LDUA subsystem controller and all end effectors are mounted in the ATIE. LDUA end effector utilities originate and terminate in the ATIE.

The TRIC includes the confinement enclosure, VPM housing adaptor, decontamination module, riser isolation valve, Manual End Effector Exchange System, and radiation monitors. The TRIC interfaces between the VPM mast housing and the tank riser used for access to the tank. It maintains confinement of the tank atmosphere, facilitates manual changeout of end effectors, and may also be used for minor maintenance tasks on the LDUA and end effectors. The decontamination module located above the riser isolation valve and below the confinement enclosure is used to decontaminate the VPM telescopic mast, LDUA, and end effector as they are withdrawn from the tank. The confinement enclosure is a stainless steel enclosure with polycarbonate windows, an access door, and glove ports on three sides.

\subsection{LIGHT DUTY UTILITY ARM OPERATIONS}

A comprehensive set of detailed operating procedures, reviewed and approved by WHC Safety and several other organizations, will govern all LDUA activities. The following discussion is a synopsis of the operations described in these procedures.

\subsubsection{Light Duty Utility Arm System Setup}

Completion of the Tank Farm Preparation Procedure will ensure that all equipment has been identified and approved for operations. A detailed inspection of the tank 24l-T-106 deployment site will be completed and the position of each piece of equipment will be marked. The next task will be to qualify tank risers for LDUA system deployment. Plug gauges will be used to 
WHC-SD-WM-SAD-038 REV 0

verify that the risers chosen for deployment are adequately plumb and have adequate internal clearance for the LDUA deployed and the independently deployed end effectors.

Following successful riser gauging, the major equipment systems of the LDUA will be transported to and set up at the Tank Farm. The OCT will be placed outside the Tank Farm fence. The ATIE will be placed in the vicinity of the riser chosen for the LDUA deployment. The fiber optic umbilical cable will be connected between the ATIE and the OCT. The PDS will be placed inside the Tank Farm near the other equipment, connected to a 480 VAC ma in power source (either a portable generator or utility power). Power cables will also be connected between the PDS and the ATIE, and between the OCT and the main power source.

The TRIC subsystem will be attached to the riser chosen for deployment of the LDUA. This installation process will be done in two steps. First, the riser isolation valve will be attached to the tank riser after electrical bonding and vapor sampling required by Tank Farm controls are completed. Then the rest of the TRIC will be attached to the riser isolation valve by a quickdisconnect joint. The TRIC's decontamination module will be connected to the DWSS, and the radiation monitors and riser isolation valve will be connected to support circuits in the ATIE. During LDUA operations, the riser isolation valve will be manually operated to provide access to the tank or to isolate the tank atmosphere from the TRIC.

The LDUA System will be transported to the tank using the MDS which will be positioned near the TRIC so that the VPM will be properly aligned to the TRIC when it is elevated. The MDS will be connected to the PDS so that its hydraulics can be powered up. The MDS outriggers will be extended and locked to provide a firm base for LDUA deployment. Load pads will be provided for the outriggers to match the soil and surface conditions. The control pendant attached to the MDS will be used to upend, position, and align the VPM housing to mate with the TRIC. A contamination control boundary will be established between the TRIC and the VPM housing using the flexible mast housing adapter (compliant joint). The tank pressure sense line for the purge system will be connected between the TRIC decontamination module and the VPM housing. With the mating to the TRIC complete, the MDS and VPM umbilical cable will be connected to the ATIE and full control will be transferred to the LDUA console and supervisory control system inside the OCT. The optical alignment scope (OAS) end effector will be used to finalize the position of the VPM housing to ensure that the VPM and LDUA are accurately aligned with the riser to provide a clear path for entering the tank, then the VPM (mechanical and software) locks will be set to prevent unwanted movement.

\subsubsection{Light Duty Utility Arm System Operation}

To initiate an in-tank operations campaign, the OAS end-effector will be installed and used first to verify LDUA alignment with respect to the riser. other end effectors will then be selected for the desired in-tank operations. The installation of all end effectors to the LDUA will be accomplished within the TRIC, utilizing a manual end-effector exchange system to assist the operator in positioning the end effector and attaching it to the LDUA. Following end effector attachment, the VPM, LDUA, and end effector will be 
lowered through the TRIC and the decontamination system and into the tank through the tank isolation valve and riser. These operations will usually be performed from the OCT; however, the MDS control pendant can provide simple operation of LDUA and VPM for recovery or maintenance activities.

Operation of the LDUA and the end effectors inside the waste tank will be performed from the OCT using supervisory control (automated sequences) or by teleoperation (manual control) using graphic computer displays to monitor and control the equipment, and on-board and overview cameras to provide direct visual feedback to the operator. After lowering the VPM tubes to the desired elevation in the tank, the arm will position end effectors to perform their in-tank functions. End effectors will normally be operated from the SCADAS, which will also record the data collected by end effector instrumentation. It is anticipated that a typical campaign will last one to two weeks. During this period, multiple end effector exchanges may be performed without removing the VPM housing from the TRIC. Gross decontamination of the deployment tubes, arm, and end effectors will take place during these exchanges as the components are withdrawn through the decontamination module.

It is expected that the arm and end-effectors will be retracted into the VPM housing during the off-shift and will be moved to the area of lowest radiation level inside the tank during working shifts when not busy. During periods of severe weather, the end effector will be removed from the arm and the arm and mast tubes will be withdrawn from the tank and isolated in the VPM housing.

\subsubsection{Light Duty Utility Arm System Disassembly}

When in-tank operations have been completed, the end effector will be dismounted from the LDUA and the deployment tubes and arm will be retracted into the VPM housing. The VPM housing will be sealed to contain any residual contamination on the internal components before the VPM housing is detached from the TRIC. The VPM housing will then be lowered to the horizontal position on the MDS for transport and storage. The independently deployed end effectors are placed in their shipping and storage containers and secured for transport and storage. The TRIC will be removed from the riser, and the riser will be closed. All TRIC components will be packaged for transport and storage. All signal and power cables will be disconnected and recovered. All support equipment (ATIE, PDS, PASS, OCT, PIM, OVS, etc.) will be made ready for transport and storage. 


\subsection{IDENT IFICATION OF HAZARDS}

\subsection{HAZARD AND OPERABILITY STUDY}

A HAZOP study (Appendix A) initiated the safety review process for LDUA operations at the Tank Farms. The scope of the HAZOP included the LDUA Baseline System and hazards associated with deployment in all 177 Hanford HLW tanks whether they are on a Watchlist or not. Documents used during this HAZOP included the following:

- LDUA system design documentation including Drawings, Detailed System Design Package, project file letters, test procedures, test reports, failure modes and effects analysis, and Civil/Structural analys is reports.

The results of the LDUA hazards evaluation include a number of postulated abnormal events which were ranked by team members with respect to safety consequences. The results of the first cut, qualitative consensus estimates of the safety severity of the consequences, were ranked by a qualitative a)phanumeric "S" system where SO indicates the lowest consequences and S3 identifies events with the greatest potential for consequences. It should be noted that these classifications are arbitrarily defined, with no direct extrapolation to DOE or WHC rules or regulations intended. They serve simply to organize operation and mission deviations into rough groupings for further examination if necessary. These rankings were assigned to identified deviations by group consensus, without quantitative analysis. Further explanation is provided in the complete HAZOP report.

LDUA components were grouped into seven nodes to facilitate description and evaluation in the HAZOP. The seven nodes are described in detail in the complete HAZOP study. SO rankings are not safety issues, SI rankings are minor safety concerns, $\$ 2$ rankings indicate serious safety issues that must be addressed, and S3 rankings ident ify potentially catastrophic events that require in-depth evaluation and development of controls, procedures, and possible safety systems for prevention and mitigation. Some deviations have more than one consequence ranking (such as $\$ 2 / \$ 3$ ), generally because two possible outcomes were postulated based on different accident conditions or assumptions. Also, some redundancy is present in the deviations as some causes lead to multiple consequences (e.g., pump overspeed results in both increased flow and line pressure).

For all tank operations, which include those for tanks which have flammable gas controls, there are a total of 40 deviations ranked $S 2$ and 35 ranked 53 in the HAZOP logsheets (see Table 2 in Appendix A).

\subsection{TANK 241-T-106 HAZARD AND OPERABILITY STUDY}

It was necessary to separate the off-normal events applicable to tanks that do not have flammable gas controls from those identified in the HAZOP for a 11 tanks. The events specific to operations in tank 241-T-106 were then evaluated and addressed in this safety assessment. Table $3-1$ shows the number of events associated with each node for tank 241-T-106 operations only. The 
Table 3-1 events are a subset of the complete set of off-normal events identified in the HAZOP for all tank operations.

Table 3-1. Tabulation of Tank 241-T-106 Events by Consequence Rank for Each Node.

\begin{tabular}{|l|c|c|c|c|c|}
\hline \multicolumn{1}{|c|}{ Node } & S0 & S1 & S2 & S3 & Total \\
\hline 1. $\begin{array}{l}\text { Light Duty } \\
\text { Utility Arm }\end{array}$ & 6 & 30 & 2 & 0 & 38 \\
\hline 2. $\begin{array}{l}\text { Vertical } \\
\text { Positioning } \\
\text { Mast }\end{array}$ & 5 & 15 & 3 & 0 & 23 \\
\hline $3 . \quad \begin{array}{l}\text { Mobile } \\
\text { Deployment } \\
\text { System }\end{array}$ & 3 & 22 & 12 & 3 & 40 \\
\hline 4. $\begin{array}{l}\text { Tank Riser } \\
\text { Interface and } \\
\text { Confinement }\end{array}$ & 5 & 22 & 5 & 0 & 32 \\
\hline $5 . \quad$ Control system & 1 & 35 & 1 & 0 & 37 \\
\hline 6. $\begin{array}{l}\text { Operations } \\
\text { Control }\end{array}$ & 1 & 11 & 0 & 0 & 12 \\
\hline Trailer & 21 & 147 & 26 & 4 & 198 \\
\hline End effectors & 0 & 12 & 3 & 1 & 16 \\
\hline
\end{tabular}

The elimination of $f l$ ammable waste material and $f l$ ammable gas from consideration for tank 241-T-106 operations substantially reduces the overall risk. Only four $\$ 3$ consequence events are postulated for LDUA operations in tank 241-T-106, and only 26 S2 consequence events are postulated. Some of the $\$ 2$ and $\$ 3$ events identified for tanks with flammable gas controls become $\$ 1$ or 50 events for operations in a tank with a nonflammable atmosphere. The other SO and $S 1$ events remain essentially the same as postulated for all tank operations. 


\subsection{HAZARDS ANALYSIS}

Based on the results of the HAZOP study, the set of postulated accidents identified for tank 24l-T-106 LDUA operations at the Tank Farms was compiled and divided into major and minor events. Major events are those assigned an S2 or 53 consequence ranking by the HAZOP team. Minor events are the SO and sl accidents. The postulated major accidents are listed in Table 4-1. These accidents will be evaluated to ensure that they are credible and sufficiently prevented and mitigated by the LDUA system design, operating controls, and emergency procedures.

Table 4-1. Accidents Postulated for the Light Duty Utility Arm Operations at Tank 241-T-106. (2 sheets)

\begin{tabular}{|c|c|c|}
\hline Event - rank & Description & Safeguards \\
\hline $1-1-\$ 2$ & Arm fire & Low fire load, NEC design \\
\hline $1-2-52$ & Arm impacts riser & Control system interlocks, video \\
\hline $2-1-\$ 2$ & VPM falls & $\begin{array}{l}\text { Brakes, hydraulic system failsafe } \\
\text { design }\end{array}$ \\
\hline $2-2-52$ & $\begin{array}{l}\text { Mast tubes fall, damage } \\
\text { tank bottom }\end{array}$ & $\begin{array}{l}\text { Limit switches, hard stops, dual } \\
\text { cables, umbilical }\end{array}$ \\
\hline $2-3-52$ & $\begin{array}{l}\text { Mast tubes fall, damage } \\
\text { tank riser/dome }\end{array}$ & $\begin{array}{l}\text { Limit switches, hard stops, dual } \\
\text { cables, umbilical }\end{array}$ \\
\hline $3-1-\$ 2$ & Above ground fire & Standard fire safety features \\
\hline $3-2-\$ 3$ & $\begin{array}{l}\text { Load exceeds dome } \\
\text { capacity }\end{array}$ & OSDs, site prep. procedure \\
\hline $3-3-52$ & $\begin{array}{l}\text { Truck impacts } \\
\text { riser/pump }\end{array}$ & $\begin{array}{l}\text { Tank Farm (TF) administrative } \\
\text { procedures }\end{array}$ \\
\hline $3-4-52$ & $\begin{array}{l}\text { Truck move damages } \\
\text { riser }\end{array}$ & Procedures, outriggers \\
\hline $3-5-52$ & Truck falls over & $\begin{array}{l}\text { Procedures, limited stroke on } \\
\text { outrigger jacks }\end{array}$ \\
\hline $3-6-\$ 2$ & $\begin{array}{l}\text { VPM lowered with arm in } \\
\text { riser }\end{array}$ & Interlocks, software checks \\
\hline $3-7-S 2$ & Wind moves truck & Procedures, outriggers \\
\hline $3-8-S 2$ & Earthquake moves truck & Procedures, outriggers \\
\hline $3-9-53$ & $\begin{array}{l}\text { Multi-vehicle accident, } \\
\text { fire }\end{array}$ & TF procedures, outriggers, fence \\
\hline $3-10-52$ & Lightning, fire & Procedures, bonding, grounding \\
\hline
\end{tabular}


Table 4-1. Accidents Postulated for the Light Duty Utility Arm Operations at Tank 241-T-106. (2 sheets)

\begin{tabular}{|l|l|l|}
\hline Event - rank & \multicolumn{1}{|c|}{ Description } & \multicolumn{1}{|c|}{ Safeguards } \\
\hline $3-11-$ S2 & $\begin{array}{l}\text { Heavy rain, truck falls } \\
\text { over }\end{array}$ & $\begin{array}{l}\text { Site preparation, outriggers, } \\
\text { inclinometers }\end{array}$ \\
\hline $3-12-$ S3 & Aircraft crash, fire & Std. Tf controls \\
\hline $4-1-$ S2 & TRIC fire & Low fire load, std. fire safety \\
\hline $4-2-$ S2 & TRIC dropped & Procedures \\
\hline $4-3-$ S2 & $\begin{array}{l}\text { Arm inserted with riser } \\
\text { valve closed }\end{array}$ & Interlocks, software checks, \\
\hline $4-4-$ S2 & Loss of confinement & Startup checks, control system checks \\
\hline $4-5-$ S2 & Wind or seismic forces & $\begin{array}{l}\text { Designed to meet wind and seismic } \\
\text { criteria }\end{array}$ \\
\hline $5-1-$ S2 & Arm impacts tank & Software checks, emergency stop \\
\hline $7-1-$ S2 & End effector fire & Low fire load, air purge, NEC design \\
\hline $7-2-$ S3 & $\begin{array}{l}\text { Aluminum reacts gas } \\
\text { ignites }\end{array}$ & Small Al mass, gas dilutivil, boots \\
\hline 7-3 - S2 & $\begin{array}{l}\text { End effector dropped, } \\
\text { tank damaged }\end{array}$ & Restraining cables/lock pins \\
\hline
\end{tabular}

The SO and Sl consequence events recognized for tank 241-T-106 operations are listed in the HAZOP (Appendix A, Section 8.0). Most of these events are routine industrial accidents or minor anticipated events that are sufficiently prevented and mitigated by the system design or by administrative procedures as addressed in the Tank Farm Health and Safety Manual (Hewitt 1996). The non-routine accidents and potential major events identified in the HAZOP for LDUA operations have been recognized and are fully addressed by design features and existing procedures. No new operating controls are recommended to prevent or mitigate these minor consequence events.

The S2 consequence events that are recognized for tank 241-T-106 operations consist primarily of loss-of-confinement events initiated by truck accidents, falling equipment, or small fires. The only 53 events postulated for tank 24l-T-106 operations are a dome collapse, a multi-vehicle accident with fire, an aircraft crash, and ignition of hydrogen gas generated by exposure of aluminum to tank waste. Each of these events is addressed by various safeguards and existing procedures as discussed in the following section. 


\subsection{EVALUATION OF POSTULATED ACCIDENTS}

\subsubsection{NODE 1}

- 1-1 High Temperature (Electrical Fire in Arm) - It is postulated that a malfunction could cause the materials inside the arm to ignite leading to damage to the confinement boundary and the potential creation of aerosols of tank waste that could be released to the environment. This event would require a serious failure of LDUA components and the presence of contaminated materials in the tank.

- Safeguards - The LDUA is designed to National Electrical Code (NEC) specifications and, because of the selection of hydraulic fluid and insulation materials, provides a very low fire load. The arm will operate on low power electricity which is not a significant heating source. A combination of fuses, circuit breakers, and automat ic current-limiting controllers acts to limit short circuits. The FHE (Huckfeldt 1996) addresses this issue and found the LDUA design to be acceptable for preventing electrically initiated fires.

- 1-2 Special Case - Removal of the arm while it is in a flexed position could result in a collision between the arm and the tank riser that could potentialiy damage the tank and confinement boundary. Falling debris from the damaged tank could generate aerosols of tank waste that could be released to the environment.

- Safeguards - The arm control system includes software preview checks to avoid collisions between the arm and known in-tank equipment, checks to prevent excessive force including redundant shutdown if travel rate is not what was commanded, and checks for proper arm configuration before withdrawal is allowed. An additional limiting feature is the design of the hydraulic system. The force that hydraulic joints can generate is limited by two separate sets of pressure relief valves per joint. There will also be video information for the operator to confirm arm configuration. The occurrence of this accident would require failure of multiple checks in the arm control system and failure on the part of the operator to recognize an improper arm position while receiving information from two sources. This accident poses essentially the same concerns (albeit in a different tank) as the operation of the voidmeter (LANL 1995), and in the case of the LDUA is afforded similar and more numerous controls. The likelihood of this scenario is lower in tank 241-T-106, with the LDUA, than in 241-SY-101 with the voidmeter. 


\subsubsection{NODE 2}

- 2-1 No Hydraulic Flow - Catastrophic failure of the VPM hydraulic system while raising and lowering the VPM housing is postulated to allow the housing to drop back to the truck. If the resulting forces are great enough, damage to the tank is postulated. If tank damage is severe, falling tank dome debris could impact tank waste and generate aerosols that are released to the environment.

- Safeguards - The postulated failure is expected to result in a loss of VPM movement, not a fall of the VPM. The hydraulic system is designed to fail safe and includes redundant controls on supply and return lines as well as many restrictions that would provide viscous damping of VPM housing travel. After the mast is fully raised and aligned with the riser, mechanical brakes are locked in place to prevent inadvertent movement of the VPM. During VPM alignment with riser, movement is restricted to \pm 10 degrees vertically by mechanical stops.

All lifts over the tank will be evaluated by Tank Farm Operations and Engineering personnel before the activity begins to ensure minimal damage in the event of a drop accident. Standard controls are included in Hanford Hoisting and Rigging Manual. If a lift is designated as a critical lift, additional contruls will be put in place per existing procedures. The risk and associated controls for this event are essentially the same as for the voidmeter (LANL 1995).

All other objects suspended over or supported by the tank structure are required by design to comply with dome load restrictions (Dougherty, 1996). The VPM will not damage the tank in the extremely unlikely event that it falls.

- 2-2 High Hydraulic Flow - Allows mast tubes and arm to overrun the stop point. This accident is postulated to result in tank-bottom puncture or riser damage. Offsite consequences are postulated to occur only if mitigation of the soil plume is not provided in a reasonable time frame.

- Safeguards - First level protection is redundant hardware and software stop limits. Second level protection is top-of-travel limit switches used on the mast positioning system that are hardware interlocked to the drive winches control and brake circuits. Third level protection is the design margin on cables and redundant cable systems. Hard stops are designed into the mast tubes to physically limit travel. The winches have no backdrive capability and include two sets of failsafe brakes. The umbilical cables are Kevlar wrapped and covered with an overall plastic sheath that will restrain tube falls. Recovery from faults is provided by manual override feature on winches. This scenario is analogous to

\section{Del aware.}

"Kevlar is a trademark of E.I. Du Pont Nemours and Company, Wilmington, 
equipment being dropped into the tank during core sampling (Milliken 1995). Safety features and controls available to prevent these events are likewise similar, and in the case LDUA, more robust.

- 2-3 High Speed - Cable or winch for mast positioning breaks and mast(s) falls, damaging riser and/or tank. Potential exists for loss of confinement, waste aerosol generation and release to the environment.

- Safeguards - Mast positioning cable system is redundant; each is designed with a $5: 1$ margin to prevent stress failures. Although not designed to survive a free fall, hard stops on mast tubes will physically dampen any fall. The winches include failsafe brakes and the umbilical cables are Keviar wrapped and covered with an overall plastic sheath that will restrain and arrest tube falls. Recovery from faults is provided by the manual override feature on winches. As with 2-2, this scenario is also analogous to equipment being dropped into the tank during core sampling (Milliken 1995). Safety features and controls available to prevent these events are likewise similar, and in the case of LDUA, more robust.

\section{1 .3 NODE 3}

- 3-1 High Temperature - Any fire in the vicinity of the tank risers could lead to the burning of LDUA equipment and the potential release of contamination, including airborne contamination.

- Safeguards - The Tank Farm areas are maintained free of combustible materials. A fire extinguisher is available on the truck, and the Hanford Fire Department is nearby. A separate FHE was completed, and concluded "Range fires are always a concern on the Hanford Site; however the physical location of the LDUA System within the Tank Farms shall have fire breaks which, in conjunction with a well qual ified fire department, provide adequate protection." This is a risk which is generic to tank farm operations, and the same controls apply here as they do to operation of, for example, core sampling equipment (Milliken, 1995).

- 3-2 Special Case - Total weight of truck and other equipment could exceed the dome load capacity. Dome collapse is a catastrophic event that is postulated to result in offsite consequences if a fire is initiated (e.g., from rupture of a truck fuel tank).

- Safeguards - Dome load analysis and a substantial safety margin have been used to assess dome load capacity. The total weight of the truck and other equipment that will be placed on the tank dome is approximately 55,200 $\mathrm{lb}$. This equates to slightly less than 28 tons, which is well below the 100-ton live load limit for SSTs (Dougherty 1996 and WHC 1996). Before the LDUA is deployed in tank 241-T-106, a dome load analysis shall be performed to ensure that the applicable requirements (both distributed and point loads) are satisfied. The requirements are in Administrative Control 5.22, Dome Load, in Dougherty 1996. The analysis will take into account 
all loads placed on the tank since the tank was certified to be in compliance with $A C 5.22$. Examples of possible additional loads include new equipment, new concrete pads, new soil cover, as well as the equipment used to perform the activity such as cranes and the MDS.

- 3-3 Special Case - MDS truck backs into Tank Farm equipment (e.g., pump pit). This could happen when a nearby pit is covered with thin sheet metal rather than with cover blocks. This event could result in the rupture of the confinement boundary, release of contamination, injury to the driver, and a potential fire if the fuel tank ruptures.

- Safeguards - Standard Tank Farm procedures maintain low speeds in the work areas; spotters are used to direct truck movements near tank equipment; trucks have backup alarms and high ground clearance. MDS truck gas tank is located under the cab not in the rear of the vehicle.

- 3-4 Special Case - Truck moves after deployment of arm causing damage to the tank or riser.

- Safeguards - Operating procedures will specify a method to control access to the truck. Multiple procedures and operationai controls are in place and would have to fail before this event could occur. Most of the vehicle weight will be supported by outriggers that stabilize the entire MDS. This design feature limits the traction that will be available to the drive wheels of the truck, minimizing the force that could be applied to the riser. This scenario unplanned movement of the VPM, is analogous to unplanned movement of the core sample truck while deployed, and is afforded similar controls.

- 3-5 Special - Truck tips over as a result of procedural failures (e.g., failure to deploy outriggers properly).

- Safeguards - Multiple procedures and operational controls are in place and would have to fail before this event could occur. Stroke length on outrigger jacks is limited and will not allow the MDS to be overturned. This scenario is of the same type of 3-4 (i.e., untimely motion of the VPM), and is analogous to untimely motion of the core sample truck. The risk of this event has been determined to be acceptable, given the established controls, and is equal to or less than the core sampler analogue.

- 3-6 Special Case - VPM housing lowered with arm in riser - Damage to riser and tank could result leading to potential loss of confinement and release of contamination.

- Safeguards - Mechanical brakes and software locks are set before the LDUA enters a riser and prevent motion of the VPM housing. The control system monitors VPM position. Administrative procedures will verify proper configuration. This scenario is of the same type as 3-4 and 3-5 (i.e., untimely motion of the VPM), and is analogous 
to untimely motion of the core sample truck. The risk of this event has been determined to be acceptable, given the established controls and is equal to or less than the core sampler analogue.

- 3-7a External Forces - High Wind - Wind forces truck to move while mast and arm are deployed in tank causing stress on riser or tank.

- Safeguards - The MDS was designed to operate in winds up to $18 \mathrm{~m} / \mathrm{s}$ ( $40 \mathrm{mph}$ ). Operations will be curtailed as winds speeds rise. LDUA system with VPM erected and outriggers deployed is designed to $36 \mathrm{~m} / \mathrm{s}(80 \mathrm{mph})$. Inclinometers on VPM will indicate excessive movement. High winds is a hazard common to other Tank Farm operations, and administrative procedures require the person in charge to check weather forecasts.

- 3-7b External Forces - High Wind - Truck tips over due to wind prior to mast and arm being deployed in tank and strikes a riser or causes damage to dome.

- Safeguards - Housing will not be erect unless outriggers are deployed. Operations will be curtailed as winds speeds rise; housing will be lowered if severe winds are forecast.

- 3-8a External Forces - Seismic - Truck moves from seismic forces while mast and arm are deployed in tank causing stress on riser or tank.

- Safeguards - MDS includes outriggers that are designed to stabilize the entire system. The mast and manipulator are not rigidly mounted to TRIC or riser.

- 3-8b External Forces - Seismic - Truck tips over due to seismic forces prior to mast and arm being deployed into tank and strikes a riser or causes damage to dome.

- Safeguards - VPM will not be erect unless outriggers are deployed. Window of vulnerability is extremely small.

- 3-9 External Forces - Vehicle Accident - If other Tank Farm traffic is not properly controlled, an unrelated vehicle could enter the LDUA operational area and potentially impact the MDS causing tank or riser damage, and potentially cause a fire.

- Safeguards - Standard Tank Farm procedures maintain low speeds in the work areas which are fenced. Multiple operations personnel will observe and control work in the area. This scenario is analogous to operation of the core sample truck in the tank farm, and the risk is the same.

- 3-10 External Forces - Lightning - If lightning strikes the 14-m $(48-f t)$ tall MDS there is the potential for initiation of a fire and propagation to other LDUA equipment. Contaminated equipment could release radioactive and hazardous material during a fire. 
- Safeguards - The entire LDUA system is electrically bonded together and to the tank, and is grounded. Operations will be terminated whenever lightning is identified within $80 \mathrm{~km}$ (50 miles). This hazard is common to many Tank Farm operations and controlled similarly. An additional inherent safeguard exists for the tank 241-T-106 in that the tank contents are not amenable to lightning initiated fires.

- 3-11 External Forces - Heavy Rain - If a heavy rain occurs during operations of the LDUA, the supporting soil could soften or be washed away allowing the MDS to tip or fall over. Tank or riser damage could occur resulting in a release of contamination.

- Safeguards - Site preparation procedure will ensure soil stability and outrigger placement that minimizes potential for rain effects. Outrigger footpads will be used if necessary. Procedures will terminate operations in the event of heavy rain and verify MDS stability before resuming operations. Inclinometers will indicate any movement of VPM. These controls are analogous to the controls placed on operation of the core sample truck (operations are suspended whenever the stability of the dril1 platform is questionable).

- 3-12 External Forces - Helicopter or Airplane Crash - Dainage to tank and potential fire could result in a release of contamination.

- Safeguards - This event is generic to all operations at the Hanford Site. The likelihood of an airborne vehicle crashing onto tank 241-T-106 is not increased by the presence of the LDUA.

\subsubsection{NODE 4}

- 4-1 High Temperature - Fire in TRIC - An electrical fault in the decontamination module heater is postulated to initiate a fire and potentially propagate to combustible material in the TRIC resulting in the release of contaminants and burned toxics (S2). The 53 event (propagation of fire to tank) was ruled as not credible, because the decontamination heater is on the outside of the metal unit and tank 24l-T-106 operations will not involve flammable tanks.

- Safeguards - Low fire load in TRIC; heater is on the outside of a metal decontamination module and there is a fire extinguisher port on the TRIC. Each of the four heaters has an internal thermostat to turn off power. The total maximum heat for the entire decontamination module is $1500 \mathrm{~W}$. Insulation is fiberglass. With respect to the decontamination heater and the associated radiation detectors, the FHE concluded "These units have adequate circuit protection and are physically isolated from the tank vapor space. Neither of these systems represent potential ignition sources."

- 4-2 Special - Drop of TRIC from Crane - Damage to riser and tank could result in a release of contamination. 
WHC-SD-WM-SAD-038 REV 0

- Safeguards - All lifts over the tank will be evaluated by Tank Farm Operations and Engineering personnel before the activity begins to ensure minimal damage in the event of a drop accident. Preliminary analysis for putting the TRIC into place indicates the need for an impact limiter on the riser. Standard controls are included in Hanford Hoisting and Rigging Manual. If a 1 ift is designated as a critical lift, additional controls will be put in place per existing procedures. The risk and associated controls for this event are essentially the same as for the voidmeter (LANL 1995).

- 4-3 Special - Arm Inserted with Riser Valve Closed - Damage to riser and/or tank is postulated with resulting loss of confinement and release of contamination.

- Safeguards - Multiple control system logic checks and operator video information will prevent arm insertion with valve closed. Valve capacity would arrest LDUA movement without damage to valve or riser. LDUA may be damaged but because of valve size and loading capability, no damage to the valve is expected so no breach of confinement is postulated. Riser is capable of vertical loads much greater than potential forces.

- 4-4 Special - Loss of Confinement - Leaks in the riser valve, TRIC components, or compliant joint could result in a release of contamination.

- Safeguards - TRIC pressure (measured locally) and component position are all monitored. Startup procedures require confinement checks before opening the tank isolation valve. A radiation protection technician will be available during operations with the riser valve open. The risk and associated controls for this event are the same as for operation of core sampling and voidmeter.

- 4-5 External Forces - Seismic Event or High Winds - Earthquakes or high winds can impose movement to the TRIC causing potentially excessive forces on the tank riser. Damage to the riser and tank could result in loss of confinement and release of contamination. Given the low probability of earthquakes of sufficient magnitude to dislodge or overturn the MDS vehicle, and the short time the LDUA will be deployed inside tank 241-T-106, the likelihood of this event is extremely small. The risk of this accident is low.

- Safeguards - The TRIC was designed to be with in the maximum weight criteria. LDUA design calculations have shown that no riser deflection will result from the design basis wind (80 $\mathrm{mph}$ ) acting on the TRIC.

\subsubsection{NODE 5}

- 5-1 Special - Wrong Signal to Arm - Erratic response of the LDUA when inside the tank is postulated to cause damage to the confinement boundary and result in release of contamination to the air or soil. 
- Safeguards - The arm control system is designed with multiple checks and interlocks to prevent inappropriate arm movements. Maximum speed, travel, and force are all checked and limited. The world Model and OSVS provide redundant checks on arm movements. The forces that the arm can impart to the tank or riser are below the damage threshold. A thorough cold test of the LDUA will be completed to verify a 11 operations before deployment at the Tank Farm.

\subsubsection{NODE 6}

No 52 or 53 events were identified for the OCT.

\subsubsection{NODE 7}

- 7-1 High Temperature - Electrical Fire in End Effector - This event could potentially lead to a loss of confinement and release of contamination.

- Safeguards - End effectors are air-purged and contained within the end effector housing. The fire load is very low. The FHE concluded that .... The design provides adequate protection for preventing electrically initiated fire ...." The risk and associated controls for this accident are the same as for operation of other electrical equipment in the tank (LANL 1995).

- 7-2 Special - Aluminum Reaction with Waste - Loss or severe damage to certain end effectors is postulated to result in exposing internal aluminum parts to the waste. The HAZOP Team was concerned with the possibility that reactive waste could generate hydrogen when in contact with aluminum and, if other faults occurred, could result in a fire or detonation.

- Safeguards - No aluminum is exposed to the tank unless several barriers have been breached. Aluminum inside the gripper is protected from chemical reaction by a tungsten carbide coating. A stainless steel housing and separate pressure boundary protects al] other end effectors. The mass of aluminum used in the end effectors is small and the reaction rates are likely to be slow for the waste in tank 241-T-106. The loss or damage events are prevented by several design features; such events are included under NODE 1 (arm). The small volume of hydrogen gas generated will be readily swept away by the purge air and diluted in the large tank volume. Manual shutdown of the arm electrical system will minimize the potential for ignition.

- 7-3 Special - End Effector Dropped into Tank - Either the on-arm or the not-on-arm end effectors could fall into the open riser as they are being deployed if they are not properly restrained. The impact could involve potential tank damage and release of contamination. 
- Safeguards - Tank Farm procedures require that all equipment small enough to fall into a riser will be restrained by a safety wire or cable. Not-on-arm end effectors weigh less than $23 \mathrm{~kg}(50 \mathrm{lb})$ and are restrained by an umbilical of power and signal cables and by an aircraft cable that can support the full weight. The end-of-arm end effectors are attached with three positive locking latches, and are checked manually for engagement by the operator. End-of-arm end effectors weigh $34 \mathrm{~kg}(75 \mathrm{lb})$ or less and are unlikely to damage the tank if dropped. The riser isolation valve is closed during end effector changeout. This event is analogous to dropping items into the tank during core sampling activities. Controls provided to minimize the risk of these events are equivalent, and the risks are essentially the same.

\subsection{SCREENING OF POSTULATED ACCIDENTS}

Most of the postulated major accidents derived from the HAZOP and evaluated in Section 4.1 are similar to events postulated for other Tank Farm operations. Previously completed analyses within the single-shell tank (SST) authorization basis that are considered bounding for the identified LDUA can be cited to help establish the acceptability of LDUA operations at tank 241-T-106. Explanations of important details for each event are provided in the subsections that follow. A summary of the estimated risk parameters for the evaluated LOUA accident is provided in Section 5.0.

The following discussion presents an evaluation of safety impacts of the events 7 isted in Table 4-1. This discussion reflects the qualitative evaluation completed by the HAZOP team during its meetings and results of subsequent investigation of LDUA design details and relevant safety issues raised during the HAZOP meetings. The results of the evaluations are summarized in Section 5.0 and the bounding release calculations (REL) are discussed in the subsections following Table 5-1. The estimated consequences of these accidents are compared to WHC Radiological Acceptance Guidelines in Section 5.2.

- 1-1 Arm Fire - This event is addressed in the FHE and is considered to be low probability and low consequence. The arm is designed to NEC criteria for operation in hazardous environments. The construction materials are mostly nonflammable, the electric sources are low power, and ignition of a fire internal to the arm is considered extremely unlikely. If a fire occurs, no loss of confinement is postulated. The only consequences postulated result from potentially toxic gases generated by the burning of arm materials. These gas volumes are expected to be small and readily diluted by the purge air and the large tank volume. Because this event is adequately prevented by design features and mitigated by standard Hanford health and safety procedures, the risk associated with this event is extremely low.

- 1-2 Arm Impacts Riser - Removal of the arm while in a flexed position is considered an extremely unlikely event. The combination of failure of the multiple control system checks and operator failure to note the arm position from system position data and video 
data is estimated to be extremely unlikely (less than $10^{-4}$ ). Unless redundant control systems fail, the maximum force that the arm can apply to the riser is well below the damage threshold (SPAR 1994). This event is similar to that postulated for other Tank Farm operations (e.g., LANL 1995) and therefore can be maintained within the established safety basis by applying the same controls. The consequences of this extremely unlikely event are loss of confinement as a result of damage to the riser-tank. The release can be estimated using the standard release calculation (REL-1), which is based on the aerosol generation calculation from LANL 1995.

- 2-1 VPM Housing Falls to Truck - It was postulated that catastrophic failure of the hydraulic system during positioning of the VPM housing could allow the mast to fall back to its horizontal position and impact the MDS truck. This event could result in a breach of the VPM housing. Forces are not expected to be great enough to result in tank dome damage. The estimated frequency of such hardware failures is extremely unlikely as a result of a number of factors. Hydraulic hoses and a hold valve have been designed to maintain pressure within the system. First the hydraulic hose would need to fail and then the hold valve would need to fail also. In addition, this operation will occur only twice during the hot test in tank 241-T-106. Because the direction of fall is directly back down to the truck carriage, no damage to tank risers is possible. The dome of SSTs is permitted a live load of $90,900 \mathrm{~kg}$ (100 ton) (Dougherty 1996). No release from the tank is postulated as a result of a VPM housing fall on the truck.

The release of contamination from the VPM housing would be small since the equipment is initially clean and is expected to remain so during LDUA operation. The consequences are estimated to be bounded by REL-3, which is based on a previously analyzed ventilation system release.

- 2-2 Mast Tubes or Arm Fall into Tank - Tank bottom damage is postulated if the mast tubes or arm are dropped into the tank. Release to the soil may result; however, such consequences are not immediately threatening to onsite or offsite persons. This event is judged not credible since two cables or winches must fail in combination with other hardware or software failures (see 2-2 in Section 4.1.2). Since both the likelihood and consequences are evaluated to be small, the risk of this event is deemed acceptable. No new analysis is required.

- 2-3 Mast Tubes Fall on Riser - This event is similar to 2-2 except it is assumed that the falling hardware impacts the riser and damages the dome. As noted above, the combination of failures necessary to realize this event are extremely unlikely. Events of this type are similar to others postulated for authorized Tank Farm operations (e.g., LANL 1995). The consequences of this event are estimated using REL-2 which is based on prior dome collapse analysis. 
- 3-1 Above Ground Fire - The low fire loading in the Tank Farms area and the noncombustible construction materials used in LDUA equipment combine to make this a low probability event (see FHE). The potential release is associated with the slightly contaminated TRIC and mast housing components, thus the worst case consequences for tank 241-T-106 LDUA operations are minor and bounded by REL-3.

- 3-2 Excessive Dome Load - The tank dome loading must be controlled by the dome loading limits for SSTs as specified in the Interim Operational Safety Requirements (Dougherty 1996). Before the LDUA is deployed in tank 241-T-106, a dome load analysis shall be performed to ensure that the applicable requirements (both distributed and point loads) are satisfied. The requirements are in Administrative Control 5.22, Dome Load, in Dougherty 1996. The analysis will take into account all loads placed on the tank since the tank was certified to be in compliance with $A C 5.22$. Examples of possible additional loads include new equipment, new concrete pads, new soil cover, as well as the equipment used to perform the activity such as cranes and the MDS. Prior analysis indicates that the maximum live load is $90,900 \mathrm{~kg}$ (100 ton) (WHC 1996). Because excessive dome loading is controlled by existing Tank Farms procedures, this postulated event is deemed an acceptable risk. The estimated frequency of an event that results in tank damage is extremely unlikely $\left(10^{-4}\right.$ to $\left.10^{-6}\right)$ and the estimated consequences are based on release from a damaged tank (REL-2).

- 3-3 Truck Impacts Riser/Pump - Events of this type are generic to Tank Farms operations. Such events have been previously addressed in the safety assessments of other tank sampling operation such as Safety Analysis For Push-Mode And Rotary-Mode Core Sampling, WHC-SD-WM-SARR-031 (Mill iken et a1. 1995) and LANL 1995. These accidents are prevented by standard WHC controls. Because several LDUA postulated events are noted that are similar in consequence and could result in potential tank or riser damage and release of contamination, an evaluation of this type of event is included. The estimated frequency of an event that results in minor damage is untikely $\left(10^{-2}\right.$ to $\left.10^{-4}\right)$ and the estimated consequences are based on the loss of confinement release (REL-1).

- 3-4 Truck Movement with Arm in Tank - The MDS truck will be immobilized during LDUA operations. The outriggers prevent movement of the truck. Operating procedures will specify a method to control access to the truck. Failure of all the controls and the outriggers is considered extremely unlikely and is similar to other tank Farm operations that have been analyzed and approved (e.g., WHC-SD-WM-SARR-03] [Milliken et al. 1995]). The potential damage to the riser is postulated to be similar to that evaluated in 3-3 above; consequences are bounded by REL-1 or REL-2.

- 3-5 Truck Falls over - Fajlure to follow procedures could result in VPM deployment without outrigger stabilization. Combination of this error with a natural phenomenon such as seismic activity, high winds, or heavy rain could allow the truck and VPM to fall over and impact a riser. Failure of all the controls and the occurrence of 
an initiating force (e.g., high wind) is considered extremely unlikely and is similar to other Tank Farm operations that have been analyzed and approved (e.g., Milliken et al. 1995). The worst case release consequences are bounded by $\mathrm{REL}-2$.

- 3-6 VPM Housing Lowered with Arm in Riser - The multiple failures required to establish this event make it extremely unlikely to occur. This event is similar to others postulated for Tank Farm operations that have been analyzed and approved (e.g., LANL 1995). The estimated consequences are bounded by REL-1 (riser damage) or REL-2 (tank damage).

- 3-7 High Winds Move Truck - Since the MDS was designed to withstand $36 \mathrm{~m} / \mathrm{s}-(80-\mathrm{mph})$ winds, higher force winds and failure to follow shutdown procedures have been postulated to result in damage to the riser. LDUA procedures require that the VPM be lowered if wind speeds exceed $18 \mathrm{~m} / \mathrm{s}(40-\mathrm{mph})$ or if the weather forecast includes high winds. Winds in excess of $36 \mathrm{~m} / \mathrm{s}(80 \mathrm{mph})$ at the Hanford Tank Farms are unlikely, and the hot test in tank 241-T-106 will be vulnerable for only about 30 days. The combined probability of all controls failing during a period of intense wind is extremely unlikely. This event is similar to that postulated for other approved Tank Farm activities. The potential health consequences are bounded by REL-1 or REL-2.

- 3-8 Earthquake Moves Truck - The risk of seismic events are generic to Tank Farm operations and have been included in prior safety assessments. The risk of a seismic event during the brief period when the LDUA is deployed at tank 241-T-106 is less than that for other sampling operations (e.g., WHC-SD-WM-SARR-031 [Mi]liken et al. 1995]). No new analys is is necessary.

- 3-9 Multi-Vehicle Accident - Events of this type are generic to Tank Farms operations. Such events have been previously addressed in the safety assessment of other tank sampling operations. These events are prevented by standard WHC controls. The probability of this event is estimated to be extremely unlikely, and the consequences are bounded by REL-2.

- 3-10 Lightning Initiated Fire - Everits of this type are generic to Tank Farms operations. Such events have been previously addressed in the safety assessment of other tank sampling operation such as Milliken 1995 and LANL 1995. These events are applicable only to tanks containing flammable gas or significant quantities of organic nitrate. The risk is mitigated by operating restrictions during inclement weather. No new analysis is deemed necessary.

- 3-11 Truck Falls as Heavy Rain Affects Soil - The probability of heavy rain at the Hanford Tank Farms is unlikely, and the hot test is vulnerable for a period of approximately 30 days. The combined probability of failure of Hanford Tank Farm controls, heavy rain during the hot test and significant effects on soil under outriggers is extremely unlikely. The test will be suspended during extreme weather. The estimated consequences are bounded by REL-2. 
- 3-12 Aircraft Crash and Fire - Events of this type are generic to all Tank Farms operations. The risk has been evaluated in Muhlestein (1994) and deemed acceptable. The risk will not increase as a result of the LDUA hot test. No new analysis is deemed necessary.

- 4-1 TRIC Fire - A fire in the TRIC was postulated in the HAZOP and considered in the FHE. Both studies estimated the probability of such an event as extremely unlikely. The consequences are bounded by the REL-3 analysis, since the estimated release for REL-3 is generated by an energetic event (ventilation system blowout) and is expected to be conservative with respect to a small fire.

- 4-2 TRIC Dropped from Crane - It was postulated that the TRIC could be dropped during installation and damage a riser and/or the tank. Preliminary analysis for putting the TRIC into place indicates the need for an impact limiter on the riser. The TRIC will be moved into location using the requirements established in Hanford Hoisting and Rigging Manual. This operation is similar to other equipment lifts at the Tank Farms (e.g., LANL 1995) and, therefore the operation does not introduce any new unreviewed accidents. No new analysis is deemed necessary.

- 4-3 Arm Inserted with Valve Closed - Insertion of the aim while the riser isolation valve is closed is considered an extremely unlikely event. The combination of failure of valve operating procedures, the multiple control system checks, and operator failure to note the valve position from system position data and video data is required for this event to occur. If assumed to be credible, (extremely unlikely) forces are not sufficient to severely damage the confinement boundary.

- 4-4 Loss of Confinement - There are several joints in the LDUA confinement boundary that could potentially fail and leak. The release of contamination during LDUA operations is an event (4-4a) with a probability in the anticipated range (frequency of $10^{-1}$ to $1.0)$. The consequences are estimated using the approach documented in prior safety assessments (e.g., LANL 1995). The analys is is provided in REL-4. The possibility was also considered of a loss of confinement during the decontamination operation $(4-4 b)$ when a greater amount of contamination may be present near the leakage location. This event has a lower probability (unlikely), and the consequences are bounded by REL -5 .

- 4-5 External Forces on TRIC Damage Riser - The TRIC was designed to meet the maximum weight criteria for the tank riser of $13,600 \mathrm{~kg}$ $(3,0001 \mathrm{~b})$, and potential lateral forces on the riser were addressed by SPAR (ref Dave Brown 12/21/94). Maximum forces from wind have been analyzed, and are not more severe than those considered in other events (e.g., the truck movement events 3-4 and 3-7) and those considered for other Tank Farm operations (e.g., LANL 1995). The frequency is estimated as unlikely and the consequences are bounded by REL-1. 
- 5-1 Arm Control Malfunctions - Impacts Tank - Although erratic arm performance has been postulated, the numerous safeguards designed into the LDUA system render this event not credible. The arm control system provides redundant software checks to stop movement if encoders are not responding in the proper direction and at the expected rate that was commanded. A thorough cold test of the LDUA will be completed to verify all operations before in-tank operation. Further, unless redundant hydraulic system relief valves fail in addition to control system errors, the forces that the arm can impart to the tank or riser are below the damage threshold.

- 7-1 Fire in End Effector - This event was addressed in the FHE and deemed to be unlikely. The consequences of the event are not expected to be significant; no breach of confinement is postulated since the fire load is very small. Therefore no radiological release is postulated, and only minor toxic material release is possible.

- 7-2 Aluminum Reaction and Gas Burn - The exposure of internal end effector components was postulated in at least two different events. The exposure of aluminum to tank waste may generate hydrogen gas. The gas generation rate is expected to be low since the reaction rate will be slow. The small volume of gas will be readily diluted in the purge air and large tank volume. Manual shutdow: of the arm electrical system will minimize the potential for ignition. The consequences of the event are not expected to be significant; no breach of confinement is postulated since the gas volume is very dilute. Therefore, no radiological release is postulated.

- 7-3 ovs/0SVS Dropped into Tank - The possibility of tank bottom puncture was postulated as a result of an equipment drop event. Similar events have been postulated for other Tank Farm operations and have been analyzed. The LDUA equipment considered in this event is all of a much smaller mass than the equipment postulated in other analyses and found to be acceptable. One example is the mixing pump used in several tanks. The end effectors used on the LDUA weigh $34 \mathrm{~kg}$ (75 lb) or less. The other end effectors used at the $10-\mathrm{cm}$ (4-in.) risers are adequately restrained and of such a small mass that the risk of this event was considered acceptable. The frequency of occurrence is estimated as unlikely, and the consequences are bounded by REL-1. 


\subsection{CONSEQUENCES OF ACCIDENTS}

Each LDUA accident is either similar to events previousiy analyzed in SAR-006 (WHC 1989a) and SAR-034 (WHC 1989b), or its resulting impact (e.g., riser damage) is similar enough to previously analyzed events that the expected consequences can be considered bounded by the previous analysis (e.g., Breach in Passive Breather System from SAR-006). Table 5-1 summarizes the estimated frequencies and consequences for all the postulated major accidents identified for LDUA operations at tank 241-T-106 and the comparable bounding events from SAR-006 and SAR-034, which illustrates that the LDUA Hot Test is well within the current authorization basis. In Section 5-2, these accident consequences are compared to the WHC risk acceptance guidelines (RAGs). It should be noted that the estimated consequences are expected to be extremely conservative since they are based on the unit 1 iter dose values for SSTs as defined in Cowley 1996; the methodology for radiological consequences as defined in Savino 1995; and the methodology for toxic chemical consequences as defined in Van Keuren et a1. 1995. Best estimate dose calculations based on the actual concentrations of waste in tank 24l-T-106 are expected to be much lower than those based on the standardized parameters in Savino 1995 and Van Keuren et al. 1995.

LDUA operations at the Hanford Tank Farms constitute a new activity that has not been specifically authorized. However, as is illustrated by the list of postulated credible accidents for tank 241-T-106 and a comparison of these events to the postulated accidents for previously authorized activities (e.g., SAR-006 and SAR-034), the LDUA hot test in tank 241-T-106 appears to be within the authorization basis for current Tank Farm activities.

Three of the postulated accidents related to LDUA operation at tank 241-T-106 are estimated to result in similar consequences arising from damage to the tank riser and loss of confinement. This consequence category is designated REL-1. Each of these events is considered bounded by the existing authorization basis, because their estimated frequencies and consequences are within current guidelines based on similar risk analysis. The Breach in Passive Breather System event identified and evaluated in Section 9.3.1.4 of WHC 1989 a is similar to the three LDUA events designated with REL-1 consequences. This event was estimated to have a frequency of occurrence of $10^{-1}$ per year, as compared to the LDUA events that are all $10^{-2}$ per year or smalier in frequency. The consequences of the SAR-006 event were evaluated assuming a tank atmosphere concentration of $0.01 \mathrm{~g} / \mathrm{m}^{3}$ and found to be within risk guidelines. The LDUA events, analyzed in Section 5.1, assumed a slightly higher tank concentration $\left(0.016 \mathrm{~g} / \mathrm{m}^{3}\right)$ and were also found to be within the risk guidelines.

Several extremely unlikely LOUA events were postulated that are estimated to result in similar consequences arising from tank dome damage and partial collapse. This consequence category is designated REL-2. Each of these events is considered bounded by the existing authorization basis, because their estimated frequencies and consequences are within those determined for a similar event analyzed for authorized activities. The Waste Storage Tank Dome Failure event identified and evaluated in Section 9.3.1, of WHC 1989b is 
Table 5-1. Estimated Frequencies and Consequences of Light Duty Utility Arm Accidents at Tank 241-T-106.

\begin{tabular}{|c|c|c|c|}
\hline Event & Frequency range & Consequences & Bounding event from authorizat ion bas is \\
\hline 1.1 Arm Fire & Unlikely & none & NA \\
\hline 1-2 flexed Arm withdrawal & Extrenely unt ikely & REL - 1 & $\begin{array}{l}\text { SAR-006, Section 9.3.1.4 Breach in Passive Breather } \\
\text { System }\end{array}$ \\
\hline 2-1 VPM Falls & Extrenely unl ikely & REL-3 & $\begin{array}{l}\text { SAR-034, Section } 9.3 .2 \text { failure of vessel Ventilation } \\
\text { Filters }\end{array}$ \\
\hline 2-2 Mast Tubes Fall into Tank & Not credible & NA & NA \\
\hline 2-3 Mast Tubes fall on Riser & Extremely unl ikely & REL -2 & SAR-034, Section 9.3.1 Waste Storage Tank Dome Failure \\
\hline 3-1 Above Ground fire & Extremely unlikely & REL -3 & $\begin{array}{l}\text { SAR-034, Section } 9.3 .2 \text { Failure of Vessel Ventilation } \\
\text { Filters }\end{array}$ \\
\hline 3-2 Excessive Dome Load & Extremely unl ikely & REL-2 & SAR-034, Section 9.3.1 Waste Storage Tank Dome Failure \\
\hline $\begin{array}{l}\text { 3-3 Truck Impact } \\
\text { a) Riser damage } \\
\text { b) Tank damage }\end{array}$ & $\begin{array}{l}\text { Unl ikely } \\
\text { Extrenely unl ikely }\end{array}$ & $\begin{array}{l}\text { REL - } 1 \\
\text { REL-2 }\end{array}$ & $\begin{array}{l}\text { a) SAR-006, Section 9.3.1.4 Breach in Passive Breather } \\
\text { System } \\
\text { b) SAR-034, Section 9.3.1 Haste Storage Tank Dome } \\
\text { Failure }\end{array}$ \\
\hline 3-4 Truck Movement with Arm in Tank & Extremely unlikely & REL-2 & SAR-034, Section 9.3.1 waste Storage Tank Dome Failure \\
\hline 3-5 Truck falls Over & Extremely unt ikely & REL-2 & SAR-034, Section 9.3.1 waste Storage Tank Dome Failure \\
\hline 3-6 VPM Lowered with Arm in Riser & Extremely unlikely & REL-2 & SAR-034, Section 9.3.1 Waste Storage Tank Dome Failure \\
\hline 3-7 High Winds Move Truck & Extremely unlikely & REL - 2 & SAR-034, Section 9.3.1 Waste Storage Tank Dome Failure \\
\hline 3-8 Earthquake Moves Truck & Extremely unlikely & REL - 2 & SAR-034, Section 9.3 .1 waste Storage Tank Dome Failure \\
\hline 3-9 Multi-Vehicle Accident & Extremely unlikely & REL - 2 & SAR-034, Section 9.3 .1 Waste Storage Tank Dome Failure \\
\hline 3-10 Lightning Initiated fire & Extremely unl ikely & REL -3 & $\begin{array}{l}\text { SAR-034, Section } 9.3 .2 \text { Failure of Vessel Ventilation } \\
\text { Filters }\end{array}$ \\
\hline 3- $\uparrow 1$ Truck Falls as Heavy Rain Affects Soil & Extremely unlikely. & REL - 2 & SAR-034, Section 9.3.1 Waste Storage Tank Dome Failure \\
\hline 3-12 Aircraft Crash and fire & Not credible & NA & NA \\
\hline 4-1 TRIC Fire & Extremely unl ikely & REL-3 & $\begin{array}{l}\text { SAR-034, Section } 9.3 .2 \text { Failure of Vessel Ventilation } \\
\text { filters }\end{array}$ \\
\hline 4-2 IRIC Oropped from Crane & Extremely unlikely & REL -2 & SAR-034, Section 9.3.1 Waste Storage Tank Dome Failure \\
\hline 4-3 Arm Inserted with valve closed & Extremely unlikely & None & NA \\
\hline $\begin{array}{l}\text { 4-4 Loss of Conf inement } \\
\text { a) Aerosol } \\
\text { b) Liquid }\end{array}$ & $\begin{array}{l}\text { Anticipated } \\
\text { unlikely }\end{array}$ & $\begin{array}{l}\text { REL - 4 } \\
\text { REL-5 }\end{array}$ & $\begin{array}{l}\text { a) SAR-006, Section 9.3.1.4 Breach in Passive Breather } \\
\text { System } \\
\text { b) SAR-034, Section 9.3.4 Leak from Salt Well Waste } \\
\text { Transfer Piping }\end{array}$ \\
\hline 4-5 External Forces on IRIC Damage Riser & Not credible & NA & NA \\
\hline 5-1 Arm Control Mal functions - Impacts Iank & Not credible & NA & NA \\
\hline 7-1 Fire in End Effector & Extremely unl ikely & None & NA \\
\hline 7-2 Aluminum Reaction and Gas Burn & Extremely unl ikely & None & NA \\
\hline 7-3 ovs / OSvs Dropped in Tank & Unlikely & REL - 1 & $\begin{array}{l}\text { SAR-006, Section 9.3.1.4 Breach in Passive Breather } \\
\text { System }\end{array}$ \\
\hline
\end{tabular}


similar to the LDUA events designated with REL-2 consequences. This event was estimated to have a frequency of occurrence of $3.6 \times 10^{-4}$ per year, as compared to the LDUA events that are al1 $10^{-4}$ per year or smaller in frequency. The consequences of the SAR-034 dome failure event were evaluated assuming a release of $7 \mathrm{~kg}$ of waste material. The LDUA events, analyzed in Section 5.1 , estimated a release of only $0.44 \mathrm{~kg}$, and are thus well within the bounds of the previously evaluated and authorized activities.

Four of the postulated accidents related to LDUA operation at tank 241-T-106 are estimated to result in similar consequences arising from release of contamination as a result of catastrophic failure of the VPM and/or TRIC. This consequence category is designated REL-3. Each of these events is considered bounded by the existing authorization basis, because their estimated frequencies and consequences are within those determined for a similar event analyzed for authorized activities. The Failure of Ventilation Filters event identified and evaluated in Section 9.3.2 of WHC 1989b is similar to the four LDUA events designated with REL-3 consequences. This SAR-034 event was estimated to have a frequency of occurrence in the same range as the postulated LDUA events $\left(10^{-4}\right.$ to $10^{-6}$ per year), and the consequences of the SAR-034 event were evaluated assuming a release of $0.7 \mathrm{Ci}$ of respirable material. The LDUA events, analyzed in Section 5.1, estimated a release of only $0.035 \mathrm{Ci}$.

One anticipated event was postulated for LDUA operations that is estimated to result from a minor breach in confinement. The risk of this event is considered bounded by previously authorized activities, since it is similar to other events postulated for approved tank farm operations. The REL-4 event is estimated to have a similar frequency but lower consequence than similar events previously analyzed. The Breach in Passive Breather system event identified and evaluated in section 9.3.1.4 of WHC 1989a is similar to, although more severe than, the minor breach of confinement event postulated for LDUA operations. This event was estimated to have a similar frequency of occurrence of $10^{-1}$ per year, but the consequences of the SAR-006 event were evaluated assuming a direct leak of tank atmosphere to the environment. The LDUA event, analyzed in Section 5.1, assumed a leak path restricted by small breaks in seals. Therefore, the REL-4 release was estimated to be one tenth that of the REL-1 release. The estimated net consequences of the LDUA event are, therefore, well below those calculated for the similar SAR-006 event and are considered to be within the authorization basis.

One postulated LDUA event results from the release of contaminated 1 iquid. The consequence of this event was designated REL-5. This event is considered bounded by the existing authorization basis, because its estimated frequency and consequence are within those determined for a similar event analyzed for authorized activities. The Leak from Salt Well Waste Transfer Piping identified and evaluated in Section 9.3.4, of WHC 1989b is similar to the LDUA event designated with REL-5 consequences. This event was estimated to have a frequency of occurrence $9 \times 10^{-2}$ per year, as compared to the LDUA event that was estimated to have a lower frequency of $10^{-2}$ to $10^{-4}$ per year. The consequences of the SAR-034 1 iquid leak event were evaluated assuming a spill of 91 liters ( 24 gallons) of waste material. The LDUA event, analyzed 
in Section 5.1, estimated a spill of only 0.1 liter, and are thus the calculated consequences are well within the bounds of the previously evaluated and authorized activities.

\subsection{LIGHT DUTY UTILITY ARM ACCIDENT RISK}

The various events 1 isted in Table 5-1 for LDUA operations at tank 241-T-106 were evaluated and determined to be well within the risk guidelines established for Tank Farm operations (WHC-CM-4-46, [WHC 1995a Rev. 3]). The postulated accidents for LDUA operation at tank 241-T-106 are similar to events that are possible during other authorized tank farm activities. Each event is related to one of the bounding release calculations, designated as REL-1 through REL-5 in Table 5-1, and the estimated consequence calculation for each of the source terms is presented in Sections 5.1.1 through 5.1.5. These results are summarized in Table 5-2 and compared to the guideline limits in Section 5.2. The bounding release calculations are discussed below.

\subsubsection{Release Calculation 1 (REL-1), Loss of Confinement - Open Riser}

The consequences associated with any one of the group of accidents that involve loss of confinement at tank 241-T-106 can be estimated using the methodology for the unmitigated release postulated in LANL 1995 for release from an open riser in tank 241-SY-101. This consequence is referred to here as REL-1. It is calculated by assuming a one-hour continuous evolution of vapors from waste that condenses to form aerosols that are released out of an open riser. Normally these aerosols are collected by the tank vent filters. The amount of aerosol generated is dependent on the heat generation rate of the waste, and the release rate is dependent on the size and location of the opening in the confinement. The heat generation rate of the waste in tank 241-T-106 (360W) is less than that of tank 24l-SY-101 (12 KW), and the size of the postulated opening is always significantly smaller $(<30 \mathrm{~cm}$ diameter) than that of the $107-\mathrm{cm}(42-\mathrm{in}$.$) riser included in the analysis of$ tank 241-SY-101.

The release from tank 241-SY-101 was assumed to occur over a one hour period, therefore recovery from the open tank within one hour is assumed for the LDUA events at tank 241-T-106. Such recovery time is deemed reasonable since Tank Farm procedures include a variety of mitigating options for arresting unplanned releases. Thus, the consequences of this postulated LDUA accident can be estimated conservatively by assuming the following:

- Released amount is proportional to the heat generation rate $(360 / 12000)$

- Release rate is not limited by the smaller riser opening for tank 241-T-106.

The amount of waste material calculated to be released in the open riser event for tank $241-S Y-101$ is $170 \mathrm{~g}$. The amount released from an open riser (or equivalent confinement boundary breach) for tank 241-T-106 is $360 / 12,000 \times$ $170 \mathrm{~g}=5.1 \mathrm{~g}$ of waste material. Tank 241-T-106 waste has a bulk density of 
$1.39 \mathrm{~g} / \mathrm{ml}$, thus the volumetric release is $3.7 \mathrm{ml}$. Using the unit liter dose for SSTs as defined in Savino 1995, the estimated radiological dose, $D$ (effective dose equivalent in SV), can be calculated using the following:

$$
D=Q \times \times / Q \times R \times U L D
$$

where

$Q=$ the quantity of waste released as respirable airborne material (L)

$X / Q=$ atmospheric dispersion coefficient for the bounding conditions $\left(\mathrm{s} / \mathrm{m}^{3}\right)$

$\mathrm{R}=$ the breathing rate for the maximum exposed individual $\left(\mathrm{m}^{3} / \mathrm{s}\right)$

ULD = the unit liter dose for SSTs (SV/L) (Savino 1995).

For REL-1 the accident conditions are assumed to be a one-hour release, so the following parameters are used to calculate the radiological doses:

$$
\begin{aligned}
& Q=3.7 \times 10^{-3} \mathrm{~L} \\
& X / Q=1.1 \times 10^{-2} \mathrm{~s} / \mathrm{m}^{3} \text { at } 100 \mathrm{~m}, 1.9 \times 10^{-5} \text { offsite } \\
& R=3.3 \times 10^{-4} \mathrm{~m}^{3} / \mathrm{s} \\
& U L D=1.0 \times 10^{4} \mathrm{SV} / \mathrm{L}
\end{aligned}
$$

The EDE for REL-1 at $100 \mathrm{~m}$ is $1.4 \times 10^{-4} \mathrm{~Sv}$ (14 mrem), and the maximum offsite EDE is $1.8 \times 10^{-7} \mathrm{SV}(0.02 \mathrm{mrem})$.

The toxic gas release consequences can be compared to the Risk Guidelines using the methodology provided in Van Keuren et al. 1995. The parameters used in the analysis depend on the accident frequency, type of material released, release mode, and released quantity. For REL-1 there are two postulated accident frequencies, unlikely (3-3a and 7-3) and extremely unlikely (1-2). Both are evaluated here.

The type of material assumed to be released in these postulated events is aerosol generated by evaporation of supernate liquid. A release for one hour is assumed, so the continuous release mode is used for the analysis. The release rate is determined from the reference analysis for tank 24l-SY-101 and the same ratio of waste heating rate that was used for the radiological analysis $(360 / 12,000)$. The release rate is $3.7 \times 10^{-3} \mathrm{~L}$ per $3,600 \mathrm{~s}=$ $10^{-6} \mathrm{~L} / \mathrm{s}$. The sum-of-fraction value from Table 3-8 in Van Keuren et a1. 1995 for an unlikely accident is $7.5 \times 10^{\circ} \mathrm{s} / \mathrm{L}$ onsite and $5.4 \times 10^{\circ} \mathrm{s} / \mathrm{L}$ offsite. The values for an extremely unlikely event are $2.0 \times 10^{2} \mathrm{~s} / \mathrm{L}$ onsite and $4.2 \times 10^{-1} \mathrm{~s} / \mathrm{L}$ offsite. The product of the release rate and the Table $3-8$ values are all very much lower than 1.0 indicating that the toxicological consequences meet the acceptance guidelines in all cases.

It should also be noted that the toxicological guidelines are met even if the full heat load of tank 241-SY-101 is used, i.e., if the reduction factor of $360 / 12,000$ is not applied to determine the tank $241-T-106$ release rate. 


\subsubsection{Release Calculation 2 (REL-2), Partial Dome Collapse}

The consequences associated with any one of a group of accidents that involves damage to the tank dome can be bounded by estimating the release for a generic worst-case scenario (REL-2). For this group of postulated events, the worst case is defined as sufficient tank dome damage to induce the breakup and fall of the concrete and soil in a limited area around the tank riser. The radiological release postulated in this scenario is modeled by assuming the drop of concrete blocks and soil into the tank, the impact on waste supernate or underlying saltcake to generate aerosols, and the direct release of the aerosol to the environment through the resulting dome failure location. Using the approach described below, the respirable aerosol mass release can be estimated and used with the unit liter dose parameters from Savino 1995 to determine a conservative estimate of radiological consequences and with Van Keuren et al. 1995 to determine the toxicological consequences.

A complete dome collapse event results in an estimated respirable aerosol release in the range of $100 \mathrm{~kg}$. This value is determined from the upper limit for airborne material generation $\left(1 \mathrm{~kg} / \mathrm{m}^{3}\right)$ from Hinds (1982), the air volume of a typical tank $\left(3,273 \mathrm{~m}^{3}\right)$, and the fraction of airborne material that is released as respirable aerosol (0.029) from the prescription of Halverson and Mishima (1986). Thus the complete dome collapse is assumed to release $95 \mathrm{~kg}$, and the partial dome collapse can be assumed to release a fraction of $95 \mathrm{~kg}$ proportional to the collapsed volume.

The worst-case LDUA events are estimated to damage only the immediate area around a single $30 \mathrm{~cm}(12-i n$.$) riser, therefore only the partial collapse$ of the tank dome is postulated. A reasonable conservative estimate of damage is a $1.5-\mathrm{m}(5-\mathrm{ft})$ diameter region around the $30 \mathrm{~cm}(12-\mathrm{in.})$ riser. The aerosol generated by this amount of dome debris and soil falling into tank 241-T-106 can be estimated by a proportional factor to the complete dome collapse event. The upper end of the range of respirable aerosol generated from the dome collapse is $95 \mathrm{~kg}$. Applying the ratio of a $1.5-\mathrm{m}(5-\mathrm{ft})$ diameter region to the whole $22-\mathrm{m}(75-\mathrm{ft})$ dome region yields a proportional factor of $4.4 \times 10^{-3}$, and an aerosol release for the LDUA event of $0.44 \mathrm{~kg}$. Tank 24l-T-106 waste has a bulk density of $1.39 \mathrm{~g} / \mathrm{ml}$, thus the volumetric release is 0.32 liter. This aerosol is assumed to diffuse out of the passively ventilated tank and be completely released in 1 hour. The estimated release rate is $0.32 \mathrm{~L} / 3,600 \mathrm{~s}=9.0 \times 10^{-5} \mathrm{~L} / \mathrm{s}$.

The estimated radiological consequences are calculated using the same methodology as that for REL-1. The unit release dose defined for SST liquid (Van Keuren et a1. 1995) is $1.0 \times 10^{4} \mathrm{~s} / \mathrm{L}$. The onsite EDE is

$$
\begin{aligned}
& D=0 \times X / Q \times R \times U L D \\
& D=0.32 \mathrm{~L} \times 1.1 \times 10^{-2} \mathrm{~s} / \mathrm{m}^{3} \times 3.3 \times 10^{-4} \mathrm{~m}^{3} / \mathrm{s} \times 1.0 \times 10^{4} \mathrm{~s} / \mathrm{L} \\
& D=1.2 \times 10^{-2} \mathrm{~s}(1.2 \mathrm{rem}) .
\end{aligned}
$$

The offsite consequences are estimated as:

$$
\begin{aligned}
& D=0.32 \mathrm{~L} \times 1.5 \times 10^{-5} \mathrm{~s} / \mathrm{m}^{3} \times 3.3 \times 10^{-4} \mathrm{~m}^{3} / \mathrm{s} \times 1.0 \times 10^{4} \mathrm{~s} / \mathrm{L} \\
& D=1.6 \times 10^{-5} \mathrm{~s}(1.6 \mathrm{mrem}) .
\end{aligned}
$$


WHC-SD-WM-SAD-038 REV 0

To compare the toxicological consequences of REL-2 to the guidelines, the release is assumed to be a continuous 1-hour release. Each postulated accident for LDUA operations at tank 24l-T-106 that was assigned an REL-2 consequence is also designated as extremely unlikely. The sum-of-fraction values for an extremely unlikely accident from Table 3-8 in Van Keuren et al. 1995 are $2.0 \times 10^{2} \mathrm{~s} / \mathrm{L}$ onsite and $4.2 \times 10^{-1} \mathrm{~s} / \mathrm{L}$ offsite. The products of these values and the release rate $\left(9.0 \times 10^{-5} \mathrm{~L} / \mathrm{s}\right)$ are $1.8 \times 10^{-2}$ onsite and $3.8 \times 10^{-5} \mathrm{~L} / \mathrm{s}$ offsite. Thus, the toxicological guidelines are met for both onsite and offsite.

\subsubsection{Release Calculation 3 (REL-3), Rupture of VPM Housing or TRIC}

The consequences of rupture of the VPM housing or TRIC enclosure are expected to be relatively minor, similar to an anticipated contamination incident. The following calculation, based on release from a tank ventilation systern, is highly conservative since the LDUA system is clean and being used for the first time in the test at tank 241-T-106.

The consequences of such an event can be estimated using the approach for the ventilation system release event described in Milliken et al. 1995. The LDUA mast housing and TRIC enclosure are contamination control boundaries, however their inside surfaces are expected to receive much less contamination than the surfaces of a tank ventilation system. Both units are usually maintained at a positive pressure with clean purge air. The postulated release mechanism for the LDUA accident is mechanical resuspension of contamination caused by the rapid rupture of either unit during an accident (e.g., 2-1 VPM falls over or 4-2 TRIC drops from crane). The VPM and TRIC are similar in overall volume and surface area to the ventilation system, yet the amount of radiological material that collects in the VPM and TRIC are expected to be significantly less than those of the ventilation system. Further, the VPM and TRIC are initially clean and are intended to be maintained relatively clean as compared to a ventilation system. The LDUA will operate for approximately 30 days in tank 241-T-106. The ventilation system was assumed to operate for a year. Thus the contamination level is assumed to be $30 / 365$ or $8.2 \%$ of that in the ventilation system. Only the release of material plated out on the ventilation system surfaces was assumed to be similar to the VPM housing or TRIC surfaces. The material collected on the ventilation systern HEPA filter was not included.

The puff release from the surfaces of the ventilation system during a blowout failure was estimated in Milliken et. al 1995 as $9 \mathrm{ml}$. The analysis was based on the radioactive material inventory available for release from the accumulation on the inside walls of the duct for the tank ventilation systems. This quantity, ad ( $\mathrm{C} i$ ), may be estimated by the following equation:

$$
q d=C * A * q V
$$

where

$C=1.54 \times 10-4(\mathrm{Ci} \mathrm{m} / \mu \mathrm{Ci})$, a proportional constant used to establish a functional relationship between the ventilation system duct's inside surface 
area, tank headspace activity concentration, and the radioactive material accumulated on the inside duct wal1. This was derived from Van Keuren (1992) by dividing the accumulated ${ }^{137} \mathrm{Cs}$ inventory from the SY Tank Farm's $30-\mathrm{cm}$ $(12-i n$.$) diameter ventilation duct (0.07 \mathrm{Ci})$ by the inside wall surface area (about $30 \mathrm{~m}^{2}$ ) and headspace activity concentration. This equation assumes that the plateout rate of all radionuclides contained in the tank ventilating system's effluent stream plateout is about the same rate and that the radioactive material plateout varies proportionally with respect to both the plateout area (inside duct wall surface area) and the activity concentration of the tank headspace vapor.

$A=$ Area on duct wall $\left(565 \mathrm{~m}^{2}\right)$

qv = Headspace activity concentration $\left(\mu \mathrm{Ci} / \mathrm{m}^{3}\right)$, which is the product of activity concentration of tank waste material, $A C\left(\mu \mathrm{Ci} / \mathrm{m}^{3}\right)$, and the partition fraction $\left(10^{-10}\right)$.

The quantity of radioactive material available for release from the accumulation on the inside walls of the ventilation system duct work, Qd, is calculated as follows:

$$
\text { Qd }=q d / A C
$$

Substituting terms yields

$$
\begin{aligned}
\text { Qd } & =C * A * P F *\left(10^{6} \mu \mathrm{Ci} / \mathrm{Ci}\right) \\
& =\left(1.54 \times 10^{-4} \mathrm{Ci} \mathrm{m} / \mu \mathrm{Ci}\right) * 565 \mathrm{~m}^{2} * 10^{-10} * 10^{6} \mu \mathrm{Ci} / \mathrm{Ci} \\
& =8.7 \times 10^{-6} \mathrm{~m}^{3} \approx 9 \mathrm{ml} .
\end{aligned}
$$

Thus, REL-3 events are estimated to release $8.2 \%$ of $9 \mathrm{ml}$ of contamination (solid $\mathrm{HLW}$ ) as respirable aerosol. The entire release is assumed to occur over 1 minute. Using the unit release dose factors from Savino 1995, the radiological consequences estimated for the loss of confinement in LDUA components are

$$
\begin{aligned}
& D=Q \times \times / Q \times R \times \text { ULD } \\
& {[)=7.4 \times 10^{-4} \mathrm{~L} \times 3.4 \times 10^{-2} \mathrm{~s} / \mathrm{m}^{3} \times 3.3 \times 10^{-4} \mathrm{~m}^{3} / \mathrm{s} \times 2.4 \times 10^{5} \mathrm{SV} / \mathrm{L}} \\
& {[)=2.0 \times 10^{-3} \mathrm{SV}(0.2 \text { rem) onsite, and }} \\
& D=7.4 \times 10^{-4} \mathrm{~L} \times 1.9 \mathrm{E} \times 10^{-5} \mathrm{~s} / \mathrm{m}^{3} \times 3.3 \times 10^{-4} \mathrm{~m}^{3} / \mathrm{s} \times 2.4 \times 10^{5} \mathrm{SV} / \mathrm{L} \\
& D=1.1 \times 10^{-6} \mathrm{SV}\left(1.1 \times 10^{-4} \text { rem }\right) \text { offsite. }
\end{aligned}
$$

The comparison of toxicological consequences of this postulated event to the guidelines for eDUA accident is $y$ events indicates:

$$
\begin{aligned}
& 9.8 \times 10^{2} \mathrm{~s} / \mathrm{L} \times 7.4 \times 10^{-4} \mathrm{~L} / 60 \mathrm{~s}=2.5 \times 10^{-2} \text { onsite, and } \\
& 1.1 \times 10^{1} \mathrm{~s} / \mathrm{L} \times 7.4 \times 10^{-4} \mathrm{~L} / 60 \mathrm{~s}=1.4 \times 10^{-4} \text { offsite. }
\end{aligned}
$$


The guidelines are met for both the onsite and offsite location.

\subsubsection{Release Calculation $4(R E L-4)$, Aerosol Leak at TRIC}

A breach in the confinement boundary that is so severe as to allow immediate communication of tank dome atmosphere to the environment was considered in REL-1. A less severe breach is anticipated to be a more frequent event and is evaluated for application to certain postulated LDUA events $(4-4 a)$. A breach in confinement that occurs at the TRIC housing door or the riser valve, for example, will allow contamination to leak to the environment at a slow rate as compared to the REL-1 case. For a REL-4 type event, it is assumed that the release is retarded by the difficult transport path, and the net rate of respirable aerosol release is one-tenth that of the unencumbered release (analyzed in REL-1). Thus, the resulting dose consequences are one tenth those estimated for REL-1 or $1.4 \times 10^{-5} \mathrm{SV}$ (1.4 mrem) onsite and $1.8 \times 10-8 \mathrm{~Sv}(0.002 \mathrm{mrem})$ offsite.

The toxicological consequences are compared to the guidelines for events in the anticipated frequency ranges. The product of the release $\left(4.7 \times 10^{-3} \mathrm{~L}\right)$ and the sum-of-fraction value for the anticipated case is we 11 below the guideline for this postulated event.

\subsubsection{Release Calculation 5 (REL-5), Liquid Leak at Decontamination Module}

The consequences of loss of confinement as a result of damage to the LDUA equipment or tank riser were evaluated in REL-1 and REL-3; however, the consequences of loss of confinement at the decontamination module (REL-5) are expected to be different, because the possibility exists for leakage of contaminated liquid.

The accident scenario involves the leakage of contaminated liquid from the decontamination module during a postulated worst-case set of conditions. The assumptions include the withdrawal of the arm from tank 241-T-106 after it has become contaminated with waste. The liquid supernate is expected to readily drain off the arm; therefore, the amount of waste that can be withdrawn from the tank is conservatively assumed to be one liter of sludge. As the arm is withdrawn from the tank, it will be sprayed with water to decontaminate the surface, removing most of the sludge. If the postulated leak in the decontamination module is in an area where a direct release of decontamination spray can become airborne outside the module, a release quantity can be estimated. It is assumed that one tenth of the waste can be sprayed off the arm and through the leak area. A partition factor of $2.0 \times 10^{-4}$ is assumed for the fraction of respirable aerosol produced by the postulated process. The overall release quantity is:

$$
\begin{aligned}
& 1 \mathrm{~L} \times 0.1 \times 2.0 \times 10^{-4}=1.4 \times 10^{-5} \mathrm{~L} \\
& \text { The radiological consequences are: } \\
& D=Q \times \times / 0 \times \mathrm{R} \times U L \mathrm{D} \\
& D=1.4 \times 10^{-5} \times 3.4 \times 10^{-2} \mathrm{~s} / \mathrm{m}^{3} \times 3.3 \times 10^{-4} \mathrm{~m}^{3} / \mathrm{s} \times 2.4 \times 10^{5} \mathrm{~Sv} / \mathrm{L}
\end{aligned}
$$




$$
\begin{aligned}
& D=3.9 \times 10^{-5} \mathrm{~Sv}(3.9 \mathrm{mrem}) \text { onsite, and } \\
& D=1.4 \times 10^{-5} \times 1.9 \times 10^{-5} \mathrm{~s} / \mathrm{m}^{3} \times 3.3 \times 10^{-4} \mathrm{~m}^{3} / \mathrm{s} \times 2.4 \times 10^{5} \mathrm{~Sv} / \mathrm{L} \\
& D=2.2 \times 10^{-8} \mathrm{~Sv}\left(2.2 \times 10^{-6}\right. \text { rem) offsite. }
\end{aligned}
$$

The comparison of toxicological consequences of this postulated event to the guidelines for unlikely events indicates:

$$
\begin{aligned}
& 2.2 \times 10^{2} \mathrm{~L}^{-1} \times 1.4 \times 10^{-5}=3.2 \times 10^{-3} \text { onsite, and } \\
& 1.3 \times 10^{-2} \mathrm{~L}^{-1} \times 1.4 \times 10^{-5}=1.9 \times 10^{-6} \text { offsite. }
\end{aligned}
$$

The guidelines are met for both the onsite and offsite location.

The estimated radiological consequences of the bounding accidents for LDUA operation in tank 241-T-106 are 1isted in Table 5-2. It should be noted that these estimated consequences are based on the generic unit liter dose parameters for standard SSTs as defined in Savino 1995 and are very conservative. Best estimate dose calculations based on the actual radionuclide concentrations in tank 24l-T-106 would yield lower consequences than those estimated here.

Table 5-2. Estimated Radiological Consequences of Bounding Accidents for Light Duty Utility Arm Operations at Tank 241-T-106.

\begin{tabular}{|l|c|c|c|c|}
\hline $\begin{array}{c}\text { Bounding } \\
\text { analysis }\end{array}$ & Release & $\begin{array}{c}\text { Maximum onsite dose } \\
\text { Sv (rem) }\end{array}$ & $\begin{array}{c}\text { Maximum offsite dose } \\
\text { Sv (rem) }\end{array}$ \\
\hline REL-1 & $3.7 \mathrm{E}-03 \mathrm{~L}$ & $1.4 \mathrm{E}-04(1.4 \mathrm{E}-02)$ & $1.8 \mathrm{E}-07(1.8 \mathrm{E}-05)$ \\
\hline REL-2 & $8.9 \mathrm{E}-05 \mathrm{~L} / \mathrm{s}$ & $1.2 \mathrm{E}-02(1.2 \mathrm{E}-00)$ & $1.6 \mathrm{E}-05(1.6 \mathrm{E}-03)$ \\
\hline REL-3 & $7.4 \mathrm{E}-04 \mathrm{~L}$ & $2.0 \mathrm{E}-03(2.0 \mathrm{E}-01)$ & $1.1 \mathrm{E}-06(1.1 \mathrm{E}-04)$ \\
\hline REL-4 & $3.7 \mathrm{E}-04 \mathrm{~L}$ & $1.4 \mathrm{E}-05(1.4 \mathrm{E}-03)$ & $1.8 \mathrm{E}-08(1.8 \mathrm{E}-06)$ \\
\hline REL-5 & $1.4 \mathrm{E}-05 \mathrm{~L}$ & $3.9 \mathrm{E}-05(3.9 \mathrm{E}-03)$ & $2.2 \mathrm{E}-08(2.2 \mathrm{E}-06)$ \\
\hline
\end{tabular}

\subsection{RISK ACCEPTANCE GUIDELINES}

The RAGs for operation of the LDUA at the Hanford Tank Farms are provided in Safety Analysis Manual WHC-CM-4-46 (WHC 1995a). These guidelines are used routinely for comparison to the consequences of the postulated accidents. RAGs are defined for two major areas: radiological committed effective dose equivalent and toxic material exposure. To use the RAGs, a frequency and consequence for the LDUA accidents must be compared to the 1 imits specified in the manual. The estimated frequency range of LDUA accidents at tank 241-T-106 are noted in Table 5-1 and described in Section 4-2. The bounding accident consequence estimates corresponding to each accident were developed using conservative assumptions and are listed in Table 5-2. 


\subsubsection{Radiological Risk Acceptance Criteria}

The guidelines for radiological risk and toxicological risk are shown in Tables 5-3 and 5-5 as taken from WHC 1995. A qualitative frequency range is used for each event 1 isted in Table 5-1; and the corresponding consequence limit applicable to all events in that frequency range are provided in WHC 1995 and 1 isted in Tables 5-3 and 5-5.

Table 5-3. Radiological Risk Guidelines.

\begin{tabular}{|c|c|c|c|}
\hline $\begin{array}{c}\text { Frequency } \\
\text { category }\end{array}$ & $\begin{array}{c}\text { Frequency range } \\
\left(\mathrm{yr}^{-1}\right)\end{array}$ & $\begin{array}{c}\text { Onsite EDE } \\
\text { mSv (rem) }\end{array}$ & $\begin{array}{c}\text { Offsite EDE } \\
\text { mSv (rem) }\end{array}$ \\
\hline Anticipated & 1.0 to $10^{-2}$ & $10-50(1-5)$ & $0.1-5(0.01-0.5)$ \\
\hline Unlikely & $10^{-2}$ to $10^{-4}$ & $50-250(5-25)$ & $5-40(0.5-4)$ \\
\hline Extremely unlikely & $10^{-4}$ to $10^{-6}$ & $250-1000(25-100)$ & $40-250(4-25)$ \\
\hline
\end{tabular}

Table 5-4 lists the postulated accidents for LDUA operations at tank 241-T-106 that have the highest frequency in each of the five consequence categories (taken from Table 5-1). As shown, all postulated events are well within the radiological risk guidelines.

Table 5-4. Comparison of Radiological Consequences of Light Duty Utility Arm Operations at Tank 24l-T-106 with Risk Acceptance Guidelines.

\begin{tabular}{|c|c|c|c|c|c|c|}
\hline Event & $\begin{array}{c}\text { Estimated } \\
\text { frequency } \\
\text { range }\end{array}$ & $\begin{array}{c}\text { Bounding } \\
\text { analysis }\end{array}$ & $\begin{array}{c}\text { Maximum onsite } \\
\text { dose mSv (rem) }\end{array}$ & $\begin{array}{c}\text { Guideline } \\
\text { acceptable } \\
\text { dose mSv } \\
(\text { rem) }\end{array}$ & $\begin{array}{c}\text { Maximum } \\
\text { offsite } \\
\text { Dose mSv } \\
\text { (rem) }\end{array}$ & $\begin{array}{c}\text { Guidel ine } \\
\text { acceptable } \\
\text { dose mSv } \\
\text { (rem) }\end{array}$ \\
\hline $3-3 a$ & Unlikely & REL-1 & $\begin{array}{c}1.4 \mathrm{E}-01 \\
(1.4 \mathrm{E}-02)\end{array}$ & $\begin{array}{c}50-250 \\
(5-25)\end{array}$ & $\begin{array}{c}1.8 \mathrm{E}-04 \\
(1.8 \mathrm{E}-05)\end{array}$ & $\begin{array}{c}5-40 \\
(0.5-4)\end{array}$ \\
\hline $3-5$ & $\begin{array}{c}\text { Extremely } \\
\text { unlikely }\end{array}$ & REL-2 & $\begin{array}{c}1.2 \mathrm{E}+01 \\
(1.2 \mathrm{E}-00)\end{array}$ & $\begin{array}{c}250-1000 \\
(25-100)\end{array}$ & $\begin{array}{c}1.6 \mathrm{E}-02 \\
(1.6 \mathrm{E}-03)\end{array}$ & $\begin{array}{c}40-250 \\
(4-25)\end{array}$ \\
\hline 2-1 & $\begin{array}{c}\text { Extremely } \\
\text { unlikely }\end{array}$ & REL-3 & $\begin{array}{c}2.0 \mathrm{E}-00 \\
(2.0 \mathrm{E}-01)\end{array}$ & $\begin{array}{c}250-1000 \\
(25-100)\end{array}$ & $\begin{array}{c}1.1 \mathrm{E}-03 \\
(1.1 \mathrm{E}-04)\end{array}$ & $\begin{array}{c}40-250 \\
(4-25)\end{array}$ \\
\hline 4-4a & Anticipated & REL-4 & $\begin{array}{c}1.4 \mathrm{E}-02 \\
(1.4 \mathrm{E}-03)\end{array}$ & $\begin{array}{c}10-50 \\
(1-5)\end{array}$ & $\begin{array}{c}1.8 \mathrm{E}-05 \\
(1.8 \mathrm{E}-06)\end{array}$ & $\begin{array}{c}0.1-5(0.01- \\
0.5)\end{array}$ \\
\hline 4-4b & Unlikely & REL-5 & $\begin{array}{c}3.9 \mathrm{E}-03 \\
(3.9 \mathrm{E}-03)\end{array}$ & $\begin{array}{c}50-250 \\
(5-25)\end{array}$ & $\begin{array}{c}2.2 \mathrm{E}-05 \\
(2.2 \mathrm{E}-06)\end{array}$ & $\begin{array}{c}5-40 \\
(0.5-4)\end{array}$ \\
\hline
\end{tabular}


Table 5-5. Toxicological Risk Guidelines.

\begin{tabular}{|c|c|c|c|}
\hline Frequency category & Frequency range $\left(\mathrm{yr}^{-1}\right)$ & Onsite 1imit & Offsite 1imit \\
\hline Anticipated & 1 to $10^{-2}$ & ERPG-1 & PEL-TWA \\
\hline Unlikely & $10^{-2}$ to $10^{-4}$ & ERPG-2 & ERPG-1 \\
\hline Extremely unlikely & $10^{-4}$ to $10^{-6}$ & ERPT-3 & ERPG-2 \\
\hline
\end{tabular}

\subsubsection{Toxicological Risk Acceptance Guidelines}

Toxicological acceptance criteria have been developed from the guidelines presented in WHC 1995a. In the referenced material, the onsite and offsite concentration limits are given in terms of Emergency Response Planning Guidelines (ERPG) (AIHA 1989) and Permissible Exposure Limit - Time-Weighted Average (PEL-TWA). The toxicological RAGs are summarized in Table 5-5.

The methodology provided in Van Keuren et al. 1995 are used to evaluate the potential toxicological consequences of LDUA. The method employs a comparison of estimated release quantities or release rates of tank waste to the effective limits (sum-of-fractions) established by evaluating all toxic sources in specific types of tank waste. The largest sum-of-fractions for each calculation is the most limiting, and is used for accident scenario evaluations. Using the WHC-SD-WM-SARR-011 methodology, the product of the estimated release quantity and the sum-of-fraction value for a unit release is compared to a volume of 1.0 . The product is the sum of the concentration divided by ERPG values. A product less than one (1.0) indicates that the RAGs are met.

Table 5-6 lists the products determined for the toxicological consequences for the LDUA accidents in each consequence category (REL-1 to 5). In all cases, the values are well below 1.0 indicating that the postulated release will not exceed the toxicological guidelines based on the composite tank waste characteristics.

Table 5-6. Comparison of Estimated Toxicological Consequences to Guidelines. (Fraction of Guideline Limit)

\begin{tabular}{|l|c|c|c|c|c|c|}
\hline & Anticipated & Anticipated & Unlikely & Unlikely & $\begin{array}{c}\text { Extremely } \\
\text { unlikely }\end{array}$ & $\begin{array}{c}\text { Extremely } \\
\text { unlikely }\end{array}$ \\
\hline $\begin{array}{l}\text { Bounding } \\
\text { analysis }\end{array}$ & Onsite & 0ffsite & 0nsite & 0ffsite & Onsite & 0ffsite \\
\hline REL-1 & NA & NA & 7.7 E-04 & $5.6 \mathrm{E}-06$ & $2.1 \mathrm{E}-04$ & $4.3 \mathrm{E}-07$ \\
\hline REL-2 & NA & NA & NA & NA & $1.8 \mathrm{E}-02$ & $3.8 \mathrm{E}-05$ \\
\hline REL-3 & NA & NA & NA & NA & $1.2 \mathrm{E}-02$ & $1.4 \mathrm{E}-04$ \\
\hline REL-4 & $7.7 \mathrm{E}-05$ & $5.6 \mathrm{E}-07$ & NA & NA & NA & NA \\
\hline REL-5 & NA & NA & $3.2 \mathrm{E}-03$ & $1.9 \mathrm{E}-07$ & $8.2 \mathrm{E}-04$ & $1.4 \mathrm{E}-08$ \\
\hline
\end{tabular}

NA $=$ not applicable. 


\subsection{CONTROLS}

\subsection{BASIS FOR SELECTION}

The principal safety philosophy for operation of the LDUA at the Tank Farms is to keep ignition sources and flammable materials separated. The controls defined for LDUA operations are based on maintaining this safety criteria. Since activities are to be conducted in tank 241-T-106 and the design of the LDUA system conforms to NFPA 496, this principal safety criteria will be satisfied. All other safety requirements as documented in DOE Orders, WHC guidance documents, and policy and procedure manuals will be satisfied by observance of the following operational controls. These controls have been previously implemented for other Tank Farm operations.

A standard set of controls has been developed that provides assurance that safety can be maintained during routine operations at the Hanford Tank Farms. LDUA activities at Hanford tank 241-T-106 have been evaluated and found to be adequately controlled by these standard Tank Farm controls. No new additional controls are recommended specifically to address operations associated with the LDUA at tank 241-T-106. The controls are divided into two groups: generic controls and specific controls. Specific controls are listed for tank 241-T-106 operations. These controls should be implemented in the appropriate test procedure. They are not required to be implemenied via change to the Interim Operational Safety Requirements (Dougherty 1996).

\subsection{TANK 241-T-106 CONTROLS}

\subsubsection{Generic Controls}

The generic controls apply to all general operations associated with deployment of the LDUA at tank 241-T-106 and are found in 0SD-T-151-00013 (WHC 1996).

\subsubsection{Specific Controls}

\subsubsection{Light Duty Utility Arm Withdrawal and Decontamination.}

Water Addition to Tanks - To minimize changes in tank waste characterization, the water addition to the LDUA shall not exceed $1,900 \mathrm{~L}$ (500 gal) as required by OSD-T-151-0013 (WHC 1996).

6.2.2.2 Light Duty Utility Arm Operation and Testing. The increased risks of contamination and the related personnel exposure concerns from losing air purge and limping into the waste shall be avoided by operating in Type $Z$ purge (as defined in NFPA-496) for the tests in tank 241-T-106. When the LDUA is operating with Type $Z$ purge, if air purge pressure drops below a pre-set value, an alarm will be sounded; but there will not be an automatic shutdown of the electric power to the arm. An operator will need to manually shut off the power to the arm. The requirement for marual shut off will keep the arm from dropping down into the waste automatically. 


\subsection{DESCRIPTION OF SPECIAL EQUIPMENT REQUIREMENTS}

None

\subsection{DESCRIPTION OF CONTROLS FOR PREVENTION AND MITIGATION}

The approved tank 241-T-106 hot test work package will specify all applicable controls, as they will be implemented independently of LDUA deployment.

It is concluded that operations in tank 241-T-106 can be conducted safely if all controls and procedures are followed as documented. 


\subsection{REFERENCES}

AIHA, 1989, Concepts and Procedures for the Development of Emergency Response Planning Guidelines (ERPG), American Industrial Hygiene Association, Akron, Ohio.

Ballinger, M. Y., J. W. Buck, P. C. Owczarski, and J. E. Ayer, 1987, Methods for Describing Airborne Fractions of Free Fall Spills of Powders and Liquids, NUREG/CR-4997, PNL-6300, Pacific Northwest Laboratory, Richland, Washington.

Brown, D., 1994, Memo to Jerry Potter from Dave Brown (attached).

Cowley, W. L., 1996, Development of Radiological Concentrations and Unit Liter Doses for TWRS FSAR Radiological Consequence Calculations, WHC-SD-WM-SARR-037, Rev. 0, West inghouse Hanford Company, Richland, Washington.

Dougherty, L. F., 1996, Single-Shel7 Tank Interim Operational Safety Requirements, WHC-SD-WM-OSR-005, Rev. OC, Westinghouse Hanford Company, Richland, Washington.

Halverson, M. A., and J. Mishima, 1986, Initial Concepts on Energeics and Mass Releases During Nonnuclear Explosive Events in Fuel Cycle Facilities, NUREG/CR-45, PNL-5839, Pacific Northwest Laboratory, Richland, Washington.

Hewitt, E. L., 1996, Tank Farm Health and Safety Plan, WHC-SD-WM-HSP-002, Rev. 2E, West inghouse Hanford Company, Richland, Washington.

Hinds, 1982, Aerosol Technology, Properties, Behavior, and Measurement of Airborne Particles, document number and rev, John Wiley and Sons, New York, New York.

Howden, G. F., R. B. Conrad, and G. R. Kiebel, 1996, Engineering Task Plan, WHC-SD-WM-ETP-176, Rev. 0, Westinghouse Hanford Company, Richland, Washington.

Huckfeldt, R. A., 1996, Fire Hazards Evaluation for Light Duty Utility Arm System, WHC-SD-WM-FHA-018, Rev. 0, Westinghouse Hanford Company, Richland, Washington.

Kiebel, G. R., 1996, Light Duty Utility Arm Baseline System Description, WHC-SD-TD-ER-005, Rev. 0, Westinghouse Hanford Company, Richland, Washington.

Jo, 1996, Tank Characterization Report for Single Shell Tank 241-T-106, WHC-SD-WM-ER-544, Rev. 0, Westinghouse Hanford Company, Richland, Washington.

LANL, 1995, A Safety Assessment for Proposed Pump Mixing Operations to Mitigate Episodic Releases in Tank 241-SY-101, LA-UR-92-3196,

Rev. 14, Los Alamos National Laboratory, Los Alamos, New Mexico. 
Milliken, N. J. and G. R. Geschke, 1995, Safety Analysis For Push-Mode And Rotary-Mode Core Sampling, WHC-SD-WM-SARR-031, Rev. 2, Westinghouse Hanford Company, Richland, Washington.

Muhlestein, L. D., 1994, Additional Analysis Related to the MultiFunction Waste Tank Facility, WHC-SD-WM-W235A-ANAL-002, Westinghouse Hanford Company, Richland, Washington.

NFPA, 1993a, National Fire Protection Association (NFPA) Code Requirements, NFPA-496, National Fire Protection Association, Quincy, Massachusetts.

NFPA, 1993b, National Electrical Code (NEC), NFPA 70-1993, National Fire Protection Association, Quincy, Massachusetts.

Savino, A. V., 1995, Tank Waste Compositions and Atmospheric Dispersion Coefficients for Use in Accelerated Safety Analys is Consequence Assessments, WHC-SD-WM-SARR-016, Rev. 1, Westinghouse Hanford Company, Richland, Washington.

SPAR, 1994, Light Duty Utility Arm and Deployment System, Detailed Design Report, SPAR-LDUA-R.025, Spar Corporation, Toronto, Canada.

Van Keuren, J.C., Davis, J. S., and Dentler, M. L., 1995, Toxic Chiemical Considerations for Tank Farm Releases, WHC-SD-WM-SARR-0I1, Rev. 1, Westinghouse Hanford Company, Richland, Washington.

Van Keuren, J. C., 1992, 241-SY Primary Exhaust System ${ }^{137} \mathrm{Cs}$ Inventory (Internal Memo 29250-ERS-92010 dated August 3), Westinghouse Hanford Company, Richland, Washington.

WHC, 1989a, Single-Shell Tank Isolation Safety Analysis Report, WHC-SD-WM-SAR-006, Rev. 2, Westinghouse Hanford Company, Richland, Washington.

WHC, 1989b, Safety Analysis Report - Stabilization of Single-Shell Waste Storage Tanks by Salt Wel7 Jet Pumping, WHC-SD-SAR-034, Rev. 0, Westinghouse Hanford Company, Richland, Washington.

WHC, 1992, Safety Analysis and Engineering Work Practices WHC-CM-6-32, WP-5.6, "Safety Assessments," Rev. 1, Westinghouse Hanford Company, Richland, Washington.

WHC, 1994, Hanford Site Radiological Control Manual, HSRCM-1, Rev. 2, Westinghouse Hanford Company, Richland, Washington.

WHC, 1995, Nonreactor Facility Safety Analysis Manual, WHC-CM-4-46, Rev. 3, Westinghouse Hanford Company, Richland, Washington.

WHC, 1996, Operating Specifications for Single-Shel7 Waste Storage Tanks, OSD-T-151-00013, D-10, Westinghouse Hanford Company, Richland, Washington. 
APPENDIX A

HAZARD AND OPERABILITY STUDY

FOR OPERATION OF THE LIGHT DUTY UTILITY ARM

AT THE HANFORD TANK FARMS

\author{
HAZOP TEAM \\ John Bartholomew \\ Ken Bennett \\ Dennis Bowser \\ Richard Brown \\ Bruce Conrad \\ Ed Heubach \\ Bill Jaquish \\ Tom Mackey \\ Michael McElroy \\ Dan Niebuhr \\ Dan Osetek \\ Larry Thomas \\ Luis Williamson
}

March 1996 
WHC-SD-WM-SAD-038 REV 0

This page intentionally left blank. 


\section{TABLE OF CONTENTS}

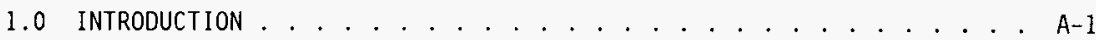

2.0 HAZOP METHOD . . . . . . . . . . . . . . . . . . . . . . . A-1

3.0 SYSTEM DESCRIPTION . . . . . . . . . . . . . . . . . . . . . . A-2

4.0 NODES AND HAZOP TABLE DESCRIPTIONS . . . . . . . . . . . . . . . A-6

4.1 NODES . . . . . . . . . . . . . . . . . . . . . . A-6

4.2 HAZOP TABLES (See Attachment) . . . . . . . . . . . . . . . . . . A-7

5.0 RESULTS . . . . . . . . . . . . . . . . . . . . . . . A-8 5.1 SUMMARY OF $52 / S 3$ EVENTS BY NODE . . . . . . . . . . . . . . . . A-9 5.2 COMMENTS FROM HAZOP TEAM . . . . . . . . . . . . . . . . . . . A-13

6.0 HAZOP TEAM. . . . . . . . . . . . . . . . . . . . . . . . . A-17

7.0 REFERENCES ............................ . . . . . . . . . . . . . . . .

8.0 HAZOP Tables........................ . . . A-20

\section{LIST OF FIGURES}

A-1 Light Duty Arm and Deployment System. . . . . . . . . . . . . . A-3 


\section{LIST OF TABLES}

A-1 Evaluation of HAZOP Technique. . . . . . . . . . . . . . . . . . A-3

A-2 Tabulation of Events by Consequence Rank for Each Node. . . . . . . A-9

6-1 Phase I Hazop Team December 1994. . . . . . . . . . . . . . . . . . A-19

6-2 Phase II and III HAZOP Team $1996 \quad$ A-20 


\section{ACRONYMS}

$\begin{array}{ll}\text { ATIE } & \text { At-Tank Instrument Enclosure } \\ \text { DOF } & \text { Degrees of Freedom } \\ \text { HAZOP } & \text { Hazard and Operability } \\ \text { HPU } & \text { Hydraulic Power Unit } \\ \text { LDUA } & \text { Light Duty Utility Arm } \\ \text { MDS } & \text { Mobile Deployment Subsystem } \\ \text { TIP } & \text { Tool Interface Plate } \\ \text { TRIC } & \text { Tank Riser Interface and Confinement } \\ \text { VPM } & \text { Vertical Positioning Mast }\end{array}$


WHC-SD-WM-SAD-038 REV 0

This page intentionally left blank. 


\subsection{INTRODUCTION}

Operation of the Light Duty Utility Arm (LDUA) at the Hanford Tank Farms is a key activity in the Hanford mission to remediate the high-level waste tanks. The LDUA will provide a mobile, remotely operated positioning system for use inside the waste tanks, and will deploy and operate a variety of end effectors to perform waste tank inspection and surveillance. Associated with the LDUA are several interfacing systems for operation of the arm. The entire LDUA and its associated support systems are the subject of this Hazard and Operability (HAZOP) Study. The LDUA system is defined in WHC-SD-TD-ER-005, Light Duty Utility Arm Baseline System Description (Keibel 1996).

The HAZOP study for the LDUA system has a two-fold purpose. First, it will identify potential hazards which are specific to the LDUA design and operation in the planned environment. Hazard identification is the essential first step in the safety analysis process. Second, the HAZOP study will identify operability issues associated with the LDUA mission. Operability issues, while not usually a safety concern, may compromise the characterization mission of the LDUA. This two-fold purpose allows the HAZOP to provide input to the follow-on safety evaluation by way of hazard identification, and input to the design and future procedures development by way of identification of operability issues.

\subsection{HAZOP METHOD}

A HAZOP study documents the effects of deviations from the design intent. of the various "process" parameters (i.e., flow, temperature, pressure, etc.). System drawings have been used to break the LDUA into nodes. Nodes are generally composed of a major piece of equipment and its surrounding associated piping, filters, valves, pumps, etc. Pertinent process parameters (guide words) such as flow, pressure, temperature, and level are chosen, and a series of questions are asked about each parameter. Each "question" concerns an abnormal condition of the process parameter (for example, 'no flow'). The HAZOP team, based on design knowledge and operational experience, postulates the causes and effects of the abnormal process condition. From this information, a qualitative estimate of the consequences of the abnormal condition is obtained. The consequence estimate can then be used as a screening tool during the safety evaluation phase to determine which deviations require further analysis.

The advantages and disadvantages of the HAZOP technique are 1 isted in Table 2-1. 
Table 2-1. Evaluation of HAZOP Technique.

\begin{tabular}{|l|l|}
\hline \multicolumn{1}{|c|}{ Advantages } & \multicolumn{1}{c|}{ Disadvantages } \\
\hline $\begin{array}{l}\text { Most effective of available } \\
\text { hazards identification methods. }\end{array}$ & $\begin{array}{l}\text { - Effort involved can be } \\
\text { significant and is proportional } \\
\text { to the complexity of the system } \\
\text { - Provides greatest assurance that the depth of detail. } \\
\text { all hazards have been } \\
\text { identified. }\end{array}$ \\
$\begin{array}{l}\text { Can provide both safety hazard } \\
\text { and operability information. }\end{array}$ & $\begin{array}{l}\text { - Results are subjective judgments } \\
\text { of participants, further } \\
\text { quantitative analyses may be } \\
\text { required. }\end{array}$ \\
\hline
\end{tabular}

The HAZOP study is documented with a series of tables (see Section 8.0) which record the results of the HAZOP team discussions.

\subsection{SYSTEM DESCRIPTION}

The LDUA system is shown in Figure $A-1$ in its deployed and operating configuration inside a typical underground tank at Hanford. The following is a summary of information found in Kiebel 1996.

The LDUA and Vertical Positioning Mast (VPM) tubes are inserted into the tank through a riser qualified by Tank Farm Operations. The Spar equipment has a maximum diameter of 10.5 inches to allow insertion through typical 12-inch risers, and the interface with the riser will be via the Tank Riser Interface Confinement (TRIC) Subsystem. The Mobile Deployment Subsystem (MDS) is used to erect the LDUA and VPM from their horizontal, stowed position into a vertical or near-vertical deployed position such that they are aligned with the riser to be used for insertion. The LDUA and VPM tubes are enclosed and supported inside a truss frame covered with panels which protects them during transport and handling.

The VPM housing provides a contamination control boundary during operations. The control subsystem performs monitoring and control of the LDUA system and enables safe, responsive, and coordinated operation of the subsystems. The LDUA is operated from the Control Console in a trailer at a remote location up to $900 \mathrm{ft}$ from the MDS. The control subsystem also provides the interface to the user's graphics-based teleoperator control station. The user's end effectors are attached to the LDUA by means of a Tool Interface Plate (TIP) and this mating/demating operation is accomplished manually using end effector exchanger equipment at the TRIC. Jumpers in the At-Tank Instrument Enclosure (ATIE) are used to connect the appropriate power signal and fluid utilities to the selected end effector. The command and control data for the system are relayed from the control station via a usersupplied link to the ATIE and the system includes the necessary Mux/Demux and conversion circuits in the At-Tank Enclosure Interface. 
WHC-SD-WM-SAD-038 REV 0

Figure A-1. Light Duty Arm and Deployment System.

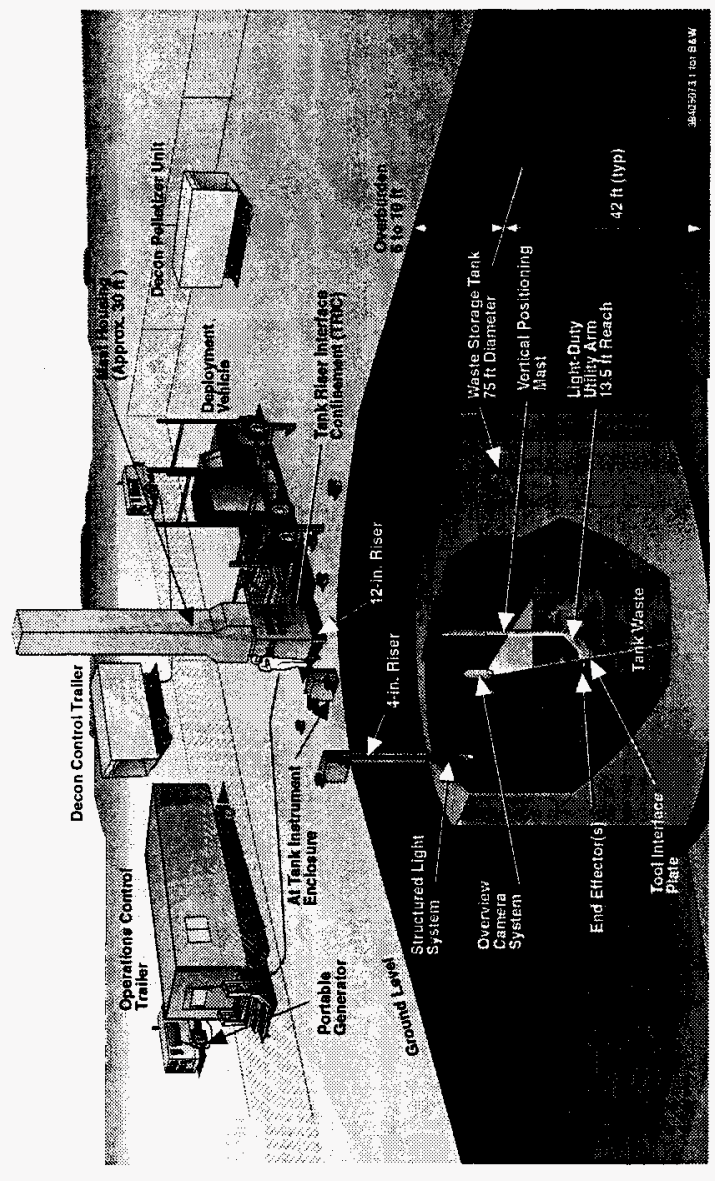


The LDUA is a seven-jointed manipulator with an off-axis reach of 13.5 feet and a payload capacity of $751 \mathrm{~b}$. The manipulator is made from 17-4PH stainless steel, and is attached to the inner tube of the VPM telescoping mast. Both the manipulator and the inner tube retract within the outer tube for stowage and transportation. The seven joints provide kinematic redundancy to enable the manipulator to maneuver itself around obstructions while eliminating or minimizing constraints on the end-point motion. This enhanced obstacle avoidance capability is expected to be particularly useful in the Hanford tanks containing large numbers of risers and previously deployed hardware. The 13.5-ft reach considerably exceeds the required 9-ft reach envelope.

Five of the seven joints need to generate large torques due to the manipulator and payload weight. These five joints are hydraulically actuated to provide compact packaging and low power dissipation for the required torque and the size limitations. All hydraulic joints use redundant actuators and controls to reduce failure modes. All LDUA arm and tube moment axis (joints) use redundant position resolvers. The two joints which do not generate large sustained torques (shoulder yaw and wrist roll) are electrically powered because their angular travel is large, the packaging is suitable, and the power dissipation is low. These electrically powered joints provide simple, effective low-speed control. In the event of a power loss or equipment failure the LDUA can assume a limp condition in which the joints are backdriven by the manipulator deadweight until it hangs vertically downwards to facilitate its recovery from the tank. During in-tank operation, silicon rubber sleeves will cover the moving parts of all manipulator hydraulic joints.

The VPM is a two-element telescopic mast which extends from an airtight container to provide the required vertical positioning of the LDUA. The container also houses the LDUA when the mast is retracted. The container is sealed to the TRIC during operation and maintains enclosure of the tank contents. When the LDUA and mast are retracted, the container is sealed by a slide valve for confinement and transportation. The telescope mast comprises two cylindrical tubes which are made of CRES 304L stainless steel for high stiffness and resistance to chemical attack. The section sizes of the tubes are optimized to obtain the maximum stiffness compatible with preserving a working clearance to the riser inside diameter. VPM tubes are raised and lowered by redundant cables. Each cable is sized to its load using a 5:1 load factor.

The MDS comprises a special purpose erection and alignment assembiy for the VPM mounted on a standard truck chassis. The special purpose assembly contains an $X-Y$ Rol] Table for longitudinal, lateral and roll alignment of the VPM to the TRIC and riser. A telescope hydraulic cylinder attached to the $X-Y$ Roll Table rotates the VPM about a trunnion mount at its lower end to elevate it to the required position. The Hydraulic Power Unit (HPU) and the Subsystem Controller are mounted on the MDS. Outriggers are used to enhance stiffness and stability of the system when deployed.

The Subsystem Controller comprises the control logic, software, drivers, and signal processing for control of the system and is located on the MDS to improve electrical performance. The control algorithms provide 6-Degrees-of-Freedom (DOF) resolved motion at the end effector, kinematic 
redundancy management, and automatic collision avoidance for pre-defined obstacles and accurate dynamic control. The Subsystem Controller is equipped with a control pendant so that the system can be operated locally with limited functionality when not controlled from the Console Subsystem. Point of control must be given up by the operator at one location before commands are accepted from the other location. This feature ensures that only one location is in control.

The Console Subsystem provides remote displays and controls to operate the system and is located in a customer-furnished trailer up to $900 \mathrm{ft}$ from the rest of the MDS. The Console Subsystem includes a workstation, hand controller for operating the manipulator, discrete controls (switches), and the Supervisory Graphics Control software which is resident in a workstation. Various cables are placed above ground to interconnect the subsystems when the LDUA system is deployed at a tank.

The interface signal conditioning electronics and electrical isolation relays for the manipulator Subsystem Controller and all End Effectors are mounted in the ATIE. The ATIE provides the fiber-optic and Mux/Demux conversion for the command and data link to and from the varjous subsystems. LDUA End Effector TIP utilities originate and terminate in the ATIE.

The TRIC includes the Confinement Enclosure, VPM mast housing adaptor, Decon Module, Riser Isolation Valve, Manual End Effector Exchange system, and Radiation Monitors. The TRIC interfaces between the VPM mast housing and the tank riser used for access to the tank. It maintains confinement of the tank atmosphere, facilitates manual changeout of end-effectors, and may also be used for minor maintenance tasks on the LDUA and end effectors. The Decontamination Module located above the Riser Isolation Valve and below the Confinement enclosure is used to decontaminate the VPM telescopic mast, LDUA, and end-effector as they are withdrawn from the tank. The Confinement Enclosure is a stainless steel enclosure with polycarbonate windows and glove ports on three sides.

\subsection{NODES AND HAZOP TABLE DESCRIPTIONS}

\subsection{NODES}

The LDUA system is not a process system, and thus lends itself somewhat differently to the HAZOP technique. Generaliy, the HAZOP method is used on systems that are made up of piping, reactors, heat exchangers, pumps, and other components that process material in a batch or continuous manner, and

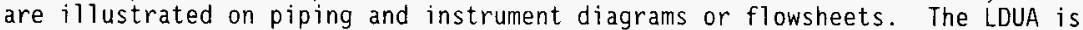
essentially a robotic arm that does not process material, and therefore must be treated differently. Many of the process parameters used in normal HAZOP analysis can be used with respect to the LDUA system (such as hydraulic fluid FLOW or operating TEMPERATURE), but the system cannot be easily broken down into nodes of flow paths for analysis. The system was therefore broken down into nodes by logical function, with some nodes composed of a single component (such as the LDUA arm itself) and some a combination of components (such as the control system). A description of the nodes follows: 
NODE 1 - Light Duty Utility Arm (LDUA) - This node is composed of the multi-joined LDUA arm. It extends from the Vertical Positioning Mast the tool interface plate (TIP), and includes all internal hydraulics, electronics, purge air flow, joint boots, and other internals.

NODE 2 - Vertical Positioning Mast (VPM) - This node is composed of the two telescoping mast tubes, the air-tight housing and hydraulic lift systems.

NODE 3 - Mobile Deployment System (MDS) - This node is composed of the truck, mast alignment table and hydraulics, the main hydraulic system that operates all system hydraulics, the Control Subsystem, and the stabilization outriggers.

NODE 4 - Tank Riser Interface and Confinement Subsystem (TRIC) - The node is composed of the TRIC structure, the decontamination module, the riser seal, and the end effector exchange system.

NODE 5-Control System - This node includes the Subsystem Controller, Control Console Subsystem, At-Tank Interface Kit, the power distribution skid and System Cable Kit.

NODE 6 - Control Trailer - This node is the physical control trailer (not the control electronics inside) and includes all the features that impact the human occupants.

NODE 7 - End Effectors - End effectors are the tools attached to the end of the LDUA arm and include four on-arm end effectors (Optical Alignment System, High Resolution Stereo Video System, Moisture Detection System, and the Gripper) and two not-on-arm end effectors (Overview Video System, Overview Stereo Video System). Not-on-arm end effectors are suspended from other risers in a tank.

\subsection{HAZOP TABLES (See Section 8)}

This section describes the format used to record the HAZOP team's discussions. The recording format (logsheet) is divided into nodes and is similar for each node. The logsheet is where the team discussions are recorded.

The first column, designated "PROCESS PARAMETER" states which parameter is being analyzed. Process parameters which may be examined include flow, pressure, temperature, reaction, speed, signal, external forces, etc. Sometimes, SPECIAL is used as a "catch-al1" parameter for issues such as utility failures and startup/shutdown/maintenance activities.

The second column "GUIDEWORD" shows guide words or variants that apply to the process parameter. There are usually several guide words applied to a process parameter, forming different deviations. Guide words which are applied to process parameters include:

- "No/none" negation of design intent

- "Low/less" quantitative decrease 
- "High/more" quantitative increase

- "Part of" qualitative decrease; intended element partially missing

- "As Well As" qualitative increase; addition of unintended element

- "Other" complete substitution; completely wrong element

- "Reverse" logical opposite of intent.

The next column, labeled "CAUSES" 1 ists the potential cause or causes of the deviation. Though team participants generally considered multiple failure events, some common sense was used to avoid absurd or obviously incredible events.

The next column is labeled "CONSEQUENCES". The consequence column contains a qualitative estimate of the result of the deviation without regard for safety features. Generally the potential release consequences or personnel harm issues are listed, along with equipment or mission impacts.

The "RANK" column shows a "first cut" qualitative consensus estimate of the safety and operational severity of the consequences. An alphanumeric system was used to designate the severity, with the following "S" rankings characterizing safety consequences:

so event has no safety system concerns for the facility worker, the nearby onsite worker, or members of the general offsite public.

S1 event results in potential injury, radiological dose consequences, or chemical exposure to the facility worker, and/or mission delay.

S2 event results in potential significant radiological consequences or chemical exposure to the onsite worker at the nearest adjacent facility.

S3 event results in potential significant radiological consequences or chemical exposure to offsite population.

The "REMARKS" column contains information that the team judged requires documentation. This includes (but is not limited to) assumptions about system operation, questions on system operation, or recommendations for changes in the planned design and operation. The "REMARK \#" column simply gives a number to the remarks for ease of reference. 


\subsection{RESULTS}

The results of the LDUA Hazard and Operability study include a number of postulated abnormal events which were ranked by the team members with respect to safety consequences. The first cut, qualitative consensus estimates of the safety severity of the consequences were rated by the alphanumeric " $S$ " system discussed above. It should be noted that these classifications are arbitrarily defined, with no direct extrapolation to DOE or WHC rules or regulations intended. They serve simply to organize operation and mission deviations into rough groupings for further examination if deemed necessary. once again, these indexes were assigned to identified deviations by group consensus, without quantitative analysis.

Table 5-1 shows the number of events considered to have the potential consequences in each category, for each study node. Note that some deviations have more than one consequence ranking (such as $52 / 53$ ), generally because two possible outcomes were postulated based on different accident conditions or assumptions. Also note that some redundancy is present in the deviations as some causes result in multiple consequences (pump overspeed results in both high flow and high line pressure, for example).

Table 5-1. Tabulation of Events by Consequence Rank for Each Node.

\begin{tabular}{|l|c|c|c|c|c|}
\hline \multicolumn{1}{|c|}{ Node } & So & Sl & S2 & S3 & Total \\
\hline 1. Light Duty Utility Arm & 6 & 26 & 7 & 7 & 46 \\
\hline 2. Vertical Positioning Mast & 5 & 15 & 3 & 3 & 26 \\
\hline 3. Mobile Deployment System & 3 & 22 & 12 & 12 & 49 \\
\hline $\begin{array}{l}\text { 4. Tank Riser Interface and } \\
\text { Confinement }\end{array}$ & 5 & 22 & 6 & 1 & 34 \\
\hline 5. Control System & 1 & 31 & 6 & 6 & 44 \\
\hline 6. Operations Control Trailer & 1 & 11 & 0 & 0 & 12 \\
\hline 7. End Effectors & 0 & 11 & 6 & 6 & 23 \\
\hline Total & 21 & 138 & 40 & 35 & 234 \\
\hline
\end{tabular}

So rankings are not safety issues, Sl rankings are minor safety concerns, \$2 rankings indicate serious safety issues that must be addressed, and the 53 rankings identify potentially catastrophic events that require in depth evaluation and development of controls, procedures and possible safety systems for prevention and mitigation. There are a total of 40 deviations with $\mathbf{3 2}$ ranking and 35 with S3 ranking in the HAZOP logsheets.

During the HAZOP meeting, team members developed a generic interpretation for determination of $\$ 3$ consequences. If an event included fire or explosion in a flammable waste tank, the consequences were assumed to be 53 . The same event without fire or explosion would be $S 2$ or lessor consequences. For example, if an event included severe damage to the tank riser and dome, 
falling debris would generate aerosols that could be transported to nearby facilities (S2). However, if the falling debris generated sparks and initiated a fire or detonation, a greater release and transport of contaminated aerosols and gases was assumed that could reach offsite locations (S3). These S2/S3 deviations are briefly discussed below with a summary of the safeguards that prevent or mitigate these deviations. Each event will be more fully addressed in the follow-on Safety Assessment.

\subsection{SUMMARY OF S2/S3 EVENTS BY NODE}

NODE 1

No/Low Flow of Arm Purge Air - Could lead to a potential ignition of flammable atmosphere in a tank. This postulated event could lead to a ca tastrophic failure of confinement, but would require the additional failure of the electrical shutdown interlock and the occurrence of a burn initiator such as a spark.

No/Low hydraulic pressure - Loss of hydraulic pressure could allow arm to relax, potentially placing end effector into waste. If the gripper is in use and has a payload of unknown material, the potential exists for a spark to be generated as the arm and payload are introduced into the waste. The potential is somewhat greater if the arm relaxation speed is high.

High Temperature (electrical fire in arm) - Could lead to burning materials in tank, potentially igniting flammables in tank and loss of confinement. This event requires failure of LDUA components and requires the presence of a flammable atmosphere and propagation of the flame beyond the boundary of the LDUA. The LDUA is expected to provide a very low fire load; a separate Fire Hazards Evaluation is being completed (Huckfeldt 1996).

High Speed (collision between arm and tank hardware) - The LDUA is constructed of non-sparking materials, and the arm control system includes software checks to prevent collisions between the arm and known in-tank equipment. So the occurrence of this accident would require failure of the arm controls system to avoid a collision and multiple faults such as the arm colliding with in-tank equipment that then falls into other in-tank equipment to generate a spark in the presence of flammable gas or waste.

High Static Charge (spark between arm and tank hardware) - This fault could lead to ignition of a flammable tank atmosphere, but is considered highly unlikely (possibly not credible) due to the extensive grounding of the LDUA system.

Special - Interlock position error - The LDUA can be operated in two modes; for flammable atmospheres the interlock shuts down arm electric power to the arm upon loss of purge air, in the nonflammable tank mode the arm maintains electric power to the arm to hold the joint breaks fixed. The system control supervisor can select either mode before arm operations begin; an error in the selection could lead to possible ignition sources in a flammable tank. 
Special - Arm withdrawal while in flexed position - If several faults occurred including failure of the main system control software validation scheme, damage to the tank riser could occur.

\section{NODE 2}

No hydraulic flow - Catastrophic failure of the VPM hydraulic system could allow the mast to drop back to the truck. If the resulting forces are great enough, damage to the tank is postulated.

High Hydraulic Flow (mast overruns stop point and free-falls) - This accident could potentially lead to a tank-bottom puncture or riser damage, but puncture is considered unlikely (verification pending). Offsite consequences are postulated to occur only if mitigation of the soit plume is not provided in a reasonable time frame.

High Speed - Cable or winch for mast positioning breaks and mast(s) falls damaging riser and /or tank.

\section{NODE 3}

S2 and $\$ 3$ events related to the hydraulic system were identified in Nodes 1 and 2 .

High Temperature - Fire at the truck could lead to burning embers that might be drawn into an open tank riser.

Special - Total weight of truck and other equipment could exceed the dome load capacity. Dome collapse is a catastrophic event that is postulated to result in offsite consequences. Dome load analysis and a substantial safety margin are used to assess deployment plans, and a site preparation procedure is conducted for each deployment.

Special - MDS truck backs into tank farm equipment (e.g., pump pit) This could happen when a nearby pit is covered with thin sheet metal rather than cover blocks. It could result in rupture of the confinement boundary, release of contamination, injury to the driver, and a potential fire if the fuel tank is ruptured. or riser.

Special - Truck moves after deployment of arm causing damage to the tank

Special-Truck tips over as a result of procedural failures; e.g., failure to deploy outriggers properly, or failure to maintain 10\% load on truck tires.

External Forces High Wind - Truck moves in wind to cause stresses on riser or tank. The MDS was designed to operate in winds up to $40 \mathrm{mph}$. Operations will be curtailed when wind speed rises.

External Forces Seismic - MDS includes outriggers that are designed to the Hanford DBE. 
External Forces Vehicle Accident - If other tank farm traffic is not properly controlled, an unrelated vehicle could enter the LDUA operational area and potentially impact the MDS causing tank or riser damage.

External Forces Lightning - If lightning strikes the $48^{\prime}$-tall MDS there is the potential for propagation to the tank and initiation of a burn or explosion.

External Forces Heavy Rain - Should a heavy rain occur during operations of the LDUA, the supporting soil could soften or be washed away allowing the MDS to tip or fall over. Jank or riser damage could occur. Procedures will terminate operations in the event of heavy rain and verify MDS stability before resumption of operations.

External Forces Helicopter or Airplane Crash - This event is generic to all operations at the Hanford site; if credible, special controls may be required to prevent such occurrence.

\section{NODE 4}

High Temperature (fire in TRIC) resulting from decontamination heater fault - A fire could potentially propagate to combustible material in the TRIC with accompanying release of contaminants and burned toxics (S2), and embers could potentially make their way down the tank riser (S3). The S3 event was ruled out as incredible, since the decontamination heater is on the outside of the metal unit. The Fire Hazards Evaluation will address this and other fires.

Special - Spark in riser from plug gauge - The carbon steel plug gauge and the carbon steel riser provide a potential source of a spark in the event of rapid contact between the two pieces of equipment. Should this occur when a flammable atmosphere is present, a burn can be postulated. Safeguards include the monitoring of tank gas immediately before riser gauging and movement controls and software monitoring of loads during gauging. Wetting of the riser and gauge surfaces is recommended to reduce the spark potential.

Special - Loss of confinement, Drop of TRIC from crane, - Leaks in the riser valve, TRIC components, or compliant joint could result in a release of contamination. TRIC pressure, tank pressure, and component position are all monitored. Startup procedures require confinement checks prior to tank isolation valve opening. All lifts over the tank will be evaluated by Tank Farm 0perations and Engineering personnel before the activity begins to ensure minimal damage in the event of a drop accident. Standard controls are included in Hanford Hoisting and Rigging Manual. If a 1 ift is designated as a critical lift, additional controls will be put in place per existing procedures.

Special - Riser valve damage - If the LDUA is lowered into the riser before the valve is fully opened, damage to the confinement boundary may occur, severe damage to equipment may result in release outside of the TRIC. Interlocks on the valve position and detailed operating procedures are used to prevent this fault. 
External Forces Seismic Event High Winds - Earthquakes and high winds can impose moments to the TRIC causing potentially excessive forces on the tank riser. The TRIC was designed to meet the maximum weight criteria, but the maximum potential forces from wind and seismic events need to be addressed.

\section{NODE 5}

Temperature High - A fire in the electrical equipment areas, e.g., junction boxes at MDS or ATIE, could lead to airborne embers that could be drawn into a tank riser.

Special - Wrong setting on safety interlock mode or calibration errors on the system pressure gauges. These faults could lead to failure of the electrical shutdown interlock after a loss of arm purge air and a potential for ignition of flammable gases that could enter the arm.

\section{NODE 6}

Temperature High - A fire in the electrical equipment areas, e.g., junction boxes at OCT, could lead to airborne embers that could be drawn into a tank riser.

NODE 7

No/Low Flow to Pneumatic System for Gripper - A drop of gripper payload and spark was recognized as a potential spark source - Since the end effectors are made of non-sparking materials, the only spark-initiating event postulated is the impact of in tank equipment (e.g., stringer) with other in-tank equipment or surfaces that could spark. Such an event was postulated if the gripper pneumatic system were to fault during certain in-tank gripper operations.

High Flow of Pneumatic Air - This fault could result in loss of the gripper function and have similar consequences as the no-flow fault above.

No/Low Flow of Purge Air - As with the LDUA itself, the end effectors are air purged to prevent the intrusion of flammables into the internals where an electrical spark might be generated. Loss of the purge air offers the potential for a gas burn, detonation, or waste burn.

High Temperature (electrical fire in end effector) - This could also lead to ignition of tank flammables, but the end effectors are air-purged and contained within the end effector housing.

High Temperature (laser-initiated fire) - It has been postulated that the lasers used for the optical alignment system could heat aerosol particles to the ignition temperature of the tank gas or waste. A gas burn (or detonation) or waste ignition could result with $S 2$ or $\$ 3$ consequences. An investigation of this phenomenon is recommended.

Special - End effector dropped into tank - Either the on-arm or the noton-arm end effectors could fall into the open riser as they are being deployed if they are not properly restrained. The impact could involve potential ignition, gas burn or detonation. 
WHC-SD-WM-SAD-038 REV 0

\subsection{COMMENTS FROM HAZOP TEAM}

The LDUA and all supporting equipment constitute a very complex system; not all design, performance or procedural information was readily available to the HAZOP team at the time of the review. Therefore several remarks were generated that identify the issues that require further evaluation before a safety or operational concern can be finalized. Some of the remarks are recommendations for further study on phenomena pertinent to the system's operation. Many are detailed comments that explain why some deviations are considered hazardous and some are not. A few remarks relate to recommendations for controls that may be necessary. The comments from the HAZOP are 1 isted below.

NOTE: The safety assessment to which this HAZOPS is appended was produced subsequent to the completion of the HAZOPS. The status of a number of the comments has changed. The current status is shown in italics following the comment.

1-01. A placard on the hydraul ic system showing fluid requirements may be advisable to prevent incorrect fluid addition.

Status: Action is with LDUA design team to install placard.

1-02. Periodic checks recommended on flow at TIP or that a flow switch be installed at TIP or that procedures be established to restrict start of purge air at ex-tank.

Status: LDUA design team has action for follow-through on comment.

1-03. Reverse flow is not possible in arm purge air system.

Status: No further action needed.

1-04. Review of arm relaxation speed is recommended if 1 ine breaks.

Status: LDUA design team has action for follow-through on this comment.

1-05. Reverse flow is probably impossible in hydraulic system.

Status: No further action is needed.

1-06. Change in TIP material recommended or spark potential to be prevented before arm is deployed in tanks with flammable gas controls.

Status: This is not an issue for 241-T-106. Action is with LDUA design team prior to arm deployment in a tank with flammable gas controls. 
1-07. Review of boot static charge potential recommended.

Status: This is not an issue for 241-T-106. Action is with LDUA design team prior to arm deployment in a tank with flammable gas controls.

1-08. Manual decontamination of the arm may be necessary if power is lost and arm goes limp.

Status: No further action is needed. Applicable LDUA procedures are written with this contingency in mind. In 241-T-106, purge air will be operated in Type Z purge. If purge pressure is lost, manual action will be needed to cut power to arm.

1-09. The probability of damage resulting from removal of flexed arm from riser may be $<10^{-6}$.

Status: Safety assessment concluded the consequences of such an event is bounded by existing accident analyses. No further action is needed.

2-01. A check of VPM hydraulic system for rapid fall upon 7 ine break is recommended. Examine slipping potential of hydraulic fluid on brake pads in case of a hydraulic fluid line break and verify that the maximum force does not exceed dome capacity.

Status: No further action needed. Safety assessment (Section 4.1.2) shows that a rapid fall of the VPM onto the truck carriage will not damage the tank.

2-02. Verify tank-bottom puncture issue in the event of a mast free-fall and verify that tank riser maximum force is not exceeded.

Status: No further action is needed. Safety assessment (Section 4.1.2) shows that the consequences are bounded by existing analyses.

3-01. Check maximum force of fallen mast on truck/dome.

Status: No further action is needed. Safety assessment (Section 4.1.2) shows that the consequences are bounded by existing analyses.

3-02. See Fire Hazards Evaluation.

Status: No further action needed. 
3-03. Because TIP is titanium, spark potential must be resolved before use in flammable tanks.

Status: This is not an issue for 241-T-106. Action is with LOUA design team prior to arm deployment in a tank with flammable gas controls.

3-12. Probability of damage from a helicopter/airplane crash may be $<10^{-6}$.

Status: No further action needed. Probability is less than $10^{-6}$, and consequences are not increased by use of the LDUA as noted in safety assessment (Section 4.1.3).

4-01. Present review was based on use of water in decontamination system. Because water additives are being considered, a further review of the decontamination system hazards may be needed.

Status: Action is with LDUA design team, if water additives are to be used in decon system.

4-02. Local TRIC pressure monitor/alarm is recommended for the HEPA system.

Status: No further action needed. As shown in safety assessment (Section 4.1.4, under event 4-4 safeguards), the TRIC pressure wi77 be measured 70cally. The TRIC pressure, and TRIC component positions will be monitored per procedure.

4-03. Need further review of TRIC fire hazards.

Status: No further action needed. FHE has been completed (Huckfeldt 1996).

4-04. Procedures will consider wetting of risers (prior to gauging) to reduce spark potential.

Status: This is not an issue for 241-T-106. Action is with LOUA design team prior to arm deployment in a tank with flammable gas controls.

4-05. Need analysis of drop forces, should TRIC be dropped from crane.

Status: No further action needed. The indicated analysis has been performed. An impact limiter will be used over the riser for tank 241-T-106 as the TRIC is being lowered (Section 4.1.4, under event 4-2 safeguards).

4-06. Because some risers are not in good condition, site preparation procedures must qual ify risers. 
Status: No further action needed for 241-T-106. Site prep will include riser qualification for hot test.

5-01 See Fire Hazards Evaluation.

Status: No further action needed.

7-01. Does high pressure shut down air purge system? or alarm?

Status: No further action needed. See safety assessment, Section 6.2.2.2, Type $Z$ purge will be used with alarm, but no automatic shutdown.

7-02. See Fire Hazards Evaluation.

Status: No further action is needed.

7-03. Review the site Bureau of Mines study of 1aser heating of aerosol particles, and consider any outstanding safety concerns to resolve issue on laser ignition.

Status: No further action is needed. Ignition is not an issue for 241-T-106.

7-04. Verify positive engagement sensing of end effector prior to tank entry.

Status: Action is with LDUA design team for follow-through on this comment. 


\subsection{HAZOP TEAM}

The LDUA HAZOP study was conducted in three phases. Phase I was completed in late 1994 when the LDUA design was not final. The Phase I HAzOP Team is listed in Table 6-1.

Table 6-1. Phase I Hazop Team December 1994.

\begin{tabular}{|l|l|l|l|}
\hline \multicolumn{1}{|c|}{ Name } & Responsibility & Org & Phone Number \\
\hline Dave Clark & & & \\
\hline John Engstrom & & & \\
\hline Richard Guthrie & & WHC & \\
\hline Ken Bennett & & WHC & \\
\hline Gary Ketner & & & \\
\hline Gary Kiebel & & WHC & \\
\hline Mike Koch & & & \\
\hline Michael Reardon & & WHC & \\
\hline Chris Smith & & PNL & \\
\hline
\end{tabular}

Phases II and III were completed in 1996 by a team with diverse disciplines and perspectives using the results of the earlier HAZOP Study, the detailed design of the LDUA, and additional supporting documentation. Table 6-2 shows the Phase II and III HAZOP team by role and organization of origin. Some of these team members were unable to participate in each session. 
Table 6-2. Phase II and II HAZOP Team 1996

\begin{tabular}{|c|c|c|c|c|c|c|c|}
\hline \multirow{2}{*}{ Name } & \multirow{2}{*}{ Responsibility } & \multirow{2}{*}{ org } & \multirow{2}{*}{ Phone Number } & \multicolumn{4}{|c|}{ HAZOP Meetings } \\
\hline & & & & $2 / 27$ & $2 / 28$ & $3 / 14$ & $3 / 15$ \\
\hline John Bartholomew & $\begin{array}{l}\text { Hardware } \\
\text { Design }\end{array}$ & LATA & $509946-2901$ & - & - & & \\
\hline Ken Bennett & $\begin{array}{l}\text { Controls Cog. } \\
\text { Eng. LDUA } \\
\text { Engineering }\end{array}$ & WHC & $509372-3665$ & $\cdot$ & $\cdot$ & - & - \\
\hline Dennis Bowser & RL Monitor & $\mathrm{DOE}$ & $509 \quad 373-2566$ & & & $\bullet$ & $\cdot$ \\
\hline David Bragg & $\begin{array}{l}\text { W. Tank Farms } \\
\text { Ops }\end{array}$ & WHC & $509373-2899$ & & & $\bullet$ & \\
\hline Richard Brown & $\begin{array}{l}\text { TWRS Syst } \\
\text { Integr'n } \\
\end{array}$ & WHC & $509372-0780$ & & & $\bullet$ & - \\
\hline Bruce Conrad & LDUA Cog Eng & WHC & $509-376-7299$ & - & $\bullet$ & - & $\cdot$ \\
\hline Ed Heubach & $\begin{array}{l}\text { Safety } \\
\text { Analysis }\end{array}$ & WHC & $509-376-7813$ & - & & $\bullet$ & - \\
\hline Bill Jaquish & Proj Mgr & ICF & $509-376-9325$ & & & $\bullet$ & $\cdot$ \\
\hline Tom Mackey & $\begin{array}{l}\text { LDUA Design } \\
\text { Team }\end{array}$ & ICF & $509373-3823$ & & & - & - \\
\hline Michael McElroy & $\begin{array}{l}\text { Quality } \\
\text { Assurance }\end{array}$ & WHC & $509373-5588$ & - & - & $\bullet$ & \\
\hline Dan Niebuhr & Operations PIC & WHC & $509373-4930$ & & - & - & - \\
\hline Dan Osetek & $\begin{array}{l}\text { HAZOP Leader } \\
\text { Safety } \\
\text { Analysis }\end{array}$ & LATA & $505880-3407$ & - & $\bullet$ & $\cdot$ & - \\
\hline Jerry Potter & $\begin{array}{l}\text { LDUA Design } \\
\text { Team }\end{array}$ & WHC & $509376-3708$ & & & $\bullet$ & \\
\hline John Silko & $\mathrm{RL}$ Monitor & $\mathrm{DOE}$ & $509 \quad 373-9876$ & & & $\dot{-}$ & \\
\hline Larry Thomas & Nuclear Safety & WHC & $509372-2402$ & - & $\bullet$ & & \\
\hline George Vargo, Jr. & Design Eng & WHC & $\begin{array}{lll}509 & 376-5387 \\
\end{array}$ & & & $\cdot$ & \\
\hline Luis Williamson & $\begin{array}{l}\text { W. Tank Farms } \\
\text { Eng }\end{array}$ & WHC & $509376-2398$ & & & • & - \\
\hline
\end{tabular}




\subsection{REFERENCES}

CCPS, 1992, Guidelines for Hazard Evaluation Procedures, Center for Chemical Process Safety of the American Institute of Chemical Engineers, New York, New York.

Huckfeldt, R. A., 1996, Fire Hazards Evaluation for Light Duty Utility Arm System, WHC-SD-WM-FHA-018, Rev. 0, Westinghouse Hanford Company, Richland, Washington.

Kiebel, G. R., 1996, Light Duty Utility Arm Baseline System Description, WHC-SD-TD-ER-005, Rev. 0, Westinghouse Hanford Company, Richland, Washington.

Spar, 1994, Light Duty Utility Arm and Deployment System; Detai7ed Design Report, SPAR-LDUA-R-025, Spar Corporation, Toronto, Canada. 


\section{PROJECT: LDUADS HAZOP}

Table 8-1. NODE \#1: Light Duty Utility Arm (IDUA).

\begin{tabular}{|c|c|c|c|c|c|c|c|}
\hline Parameter & Guideword & Causes & Consequences & Safeguards & Rank & Remarks & RM\# \\
\hline \multirow[t]{9}{*}{$\begin{array}{l}\text { Flow } \\
\text { (hydraulic } \\
\text { fluid) }\end{array}$} & \multirow[t]{3}{*}{ No/LOW } & $\begin{array}{l}\text { No hydraulic fluid in } \\
\text { reservoir, Hydraul ic pump } \\
\text { failure }\end{array}$ & $\begin{array}{l}\text { Arm immobile (process } \\
\text { delay), potential equip } \\
\text { damage }\end{array}$ & $\begin{array}{l}\text { Hydraulic reservoir level } \\
\text { sensing, startup } \\
\text { procedures, sealed vendor } \\
\text { maintained system }\end{array}$ & s1 & & \\
\hline & & $\begin{array}{l}\text { Hydraul ic fluid line } \\
\text { break }\end{array}$ & $\begin{array}{l}\text { Spill of hydraulic fluid, } \\
\text { potential aerosol spray, } \\
\text { potential ignition, } \\
\text { chenical reaction with } \\
\text { waste, electrical short }\end{array}$ & $\begin{array}{l}\text { Hydraul ic reservoir level } \\
\text { sensing, } 2 \text { gallon } \\
\text { maximum, fluid is } \\
\text { authorized by WHC } \\
\text { environmental and } \\
\text { operations, software } \\
\text { checks prevent system } \\
\text { operation without proper } \\
\text { pressure (flow), fluid is } \\
\text { not conductive, flash } \\
\text { point is } 200^{\circ} \mathrm{C}, \text { NEC } \\
\text { design, see FHE. } \\
\end{array}$ & s1 & & \\
\hline & & Hydraulic fluid line plug & $\begin{array}{l}\text { Arm immobile (process } \\
\text { delay), potential } \\
\text { equipment damage }\end{array}$ & $\begin{array}{l}\text { Controls on hydraulic } \\
\text { fluid procurement (low } \\
\text { levels of particulates) }\end{array}$ & s1 & & \\
\hline & \multirow[t]{2}{*}{ High } & $\begin{array}{l}\text { Hydraulic valve stuck } \\
\text { open }\end{array}$ & $\begin{array}{l}\text { Loss of control of arm } \\
\text { joint }\end{array}$ & $\begin{array}{l}\text { Pressure relief valves on } \\
\text { hydraulic system with } \\
\text { excess fluid collected at } \\
\text { reservoir, sof tware } \\
\text { checks prevent system } \\
\text { operation without proper } \\
\text { pressure (flow) }\end{array}$ & s1 & & \\
\hline & & Hydraulic tine severed & See "no flow" & See "no flow" & s1 & & \\
\hline & \multirow[t]{2}{*}{$\begin{array}{l}\text { other than } \\
\text { (wrong mat' } 1 \text { ) }\end{array}$} & Wrong hydraulic fluid & $\begin{array}{l}\text { Incompatibility with } \\
\text { seals, incompatibility } \\
\text { with waste, radiation } \\
\text { damage, creates mixed } \\
\text { waste (in case of leak) }\end{array}$ & $\begin{array}{l}\text { Administrative controls } \\
\text { on hydraulic fluid type, } \\
\text { placard, no field } \\
\text { maintenance, fluid chosen } \\
\text { for its desirable } \\
\text { characteristics }\end{array}$ & s1 & $\begin{array}{l}\text { See reference letter } \\
7 E 310-94-037 \text { from Scott } \\
\text { Estey on fluid selection }\end{array}$ & \\
\hline & & Wrong valve/fittings & $\begin{array}{l}\text { Reduction in performance } \\
\text { (viscosity), erratic } \\
\text { performance }\end{array}$ & $\begin{array}{l}\text { Pre-deployment } \\
\text { operational tests, no } \\
\text { field changes, no user } \\
\text { maintainence. }\end{array}$ & 51 & $\begin{array}{l}\text { A placard on hydraulic } \\
\text { system showing fluid } \\
\text { requirements may be } \\
\text { advisable }\end{array}$ & $1-01$ \\
\hline & \multirow[t]{2}{*}{$\begin{array}{l}\text { Reverse } \\
\text { (backflow) }\end{array}$} & Pump miswired (reversed) & $\begin{array}{l}\text { Control system causes } \\
\text { shutdown }\end{array}$ & $\begin{array}{l}\text { Administrat ive controls } \\
\text { an wiring, phase rotation } \\
\text { indication in design, } \\
\text { startup procedures verify } \\
\text { flow }\end{array}$ & $\$ 1$ & & \\
\hline & & $\begin{array}{l}\text { Improper (reversed) } \\
\text { hydraulic connections }\end{array}$ & Punp damage & $\begin{array}{l}\text { Admininstrative controls } \\
\text { on hydraul ic } \\
\text { conf iguration, system } \\
\text { will not operate without } \\
\text { correct pressure ( } f(\text { low) }\end{array}$ & s1 & & \\
\hline
\end{tabular}


TabTe 8-1. NODE \#1: Light Duty Utility Arm (IDUA).

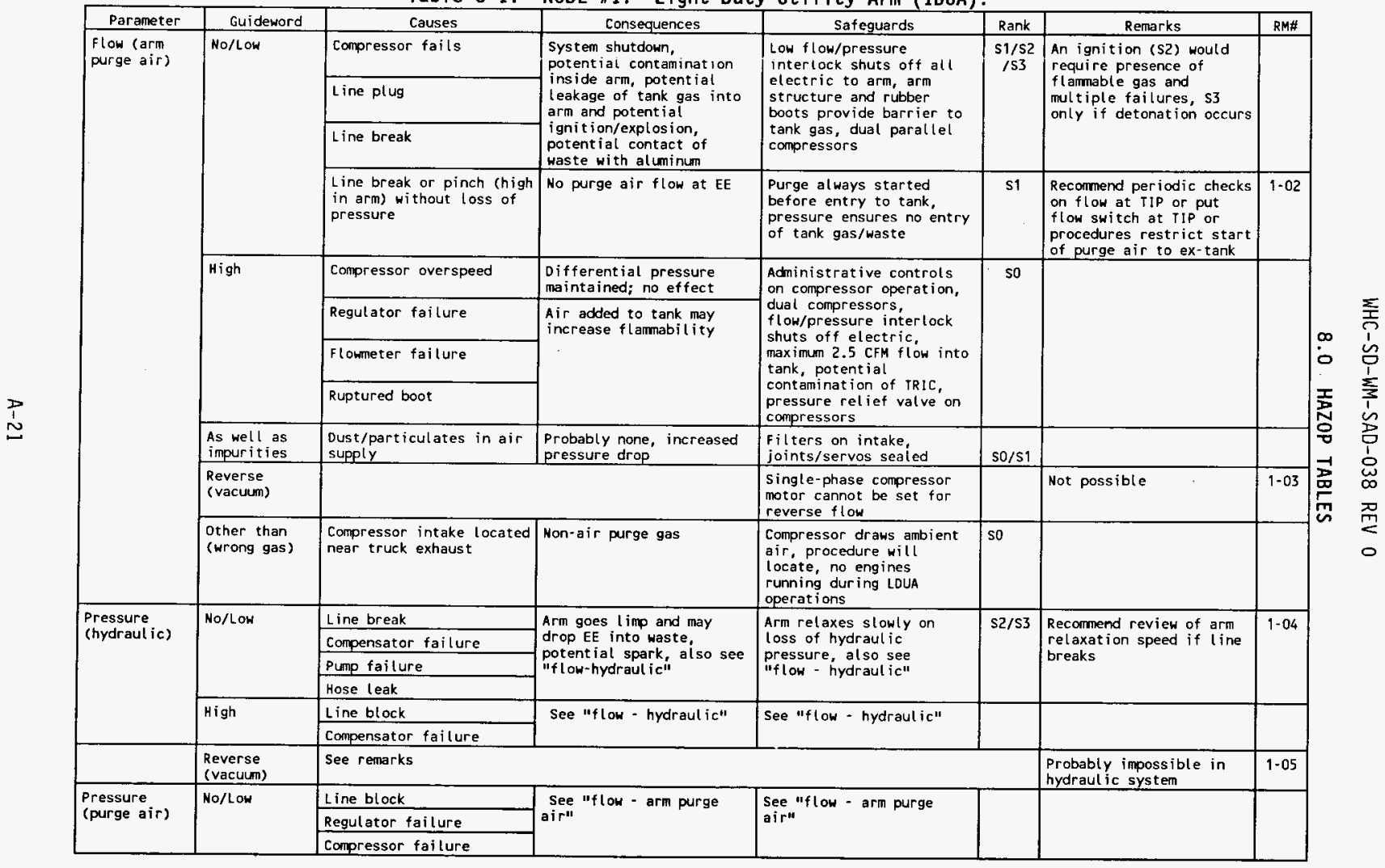


Table 8-1. NODE \#1: Light Duty Utility Arm (IDUA).

\begin{tabular}{|c|c|c|c|c|c|c|c|}
\hline Parameter. & Guideword & Causes & Consequences & Safeguards & Rank & Remarks & RM\# \\
\hline \multirow{4}{*}{$\begin{array}{l}\text { Pressure } \\
\text { (purge alr) } \\
\text { (Cont.) }\end{array}$} & \multirow{3}{*}{ High } & Boot rupture & \multirow{3}{*}{$\begin{array}{l}\text { See "flow - arm purge } \\
\text { air" }\end{array}$} & \multirow{3}{*}{$\begin{array}{l}\text { See "flow - arm purge } \\
\text { air" }\end{array}$} & & & \\
\hline & & Line block & & & & & \\
\hline & & Regulator failure & & & & & \\
\hline & $\begin{array}{l}\text { Reverse } \\
\text { (vacuum) }\end{array}$ & $\begin{array}{l}\text { See "flow - arm purge } \\
\text { air" }\end{array}$ & $\begin{array}{l}\text { See "flow - arm purge } \\
\text { air" }\end{array}$ & $\begin{array}{l}\text { See "flow - arm purge } \\
\text { air" }\end{array}$ & & & \\
\hline \multirow[t]{3}{*}{$\begin{array}{l}\text { Temperature } \\
\text { (hydraul ic } \\
\text { fluid) }\end{array}$} & \multirow[t]{2}{*}{$\begin{array}{l}\text { No/Low } \\
\text { (freezing, } \\
\text { cold) }\end{array}$} & Storage in cold weather & $\begin{array}{l}\text { None of consequence, } \\
\text { initial slow response, } \\
\text { slight operational delay }\end{array}$ & $\begin{array}{l}\text { Fluid heater turns on } \\
\text { below } 20^{\circ} \mathrm{C}\end{array}$ & so/s1 & & \\
\hline & & $\begin{array}{l}\text { Hydraul ic fluid heater } \\
\text { failure in cold weather }\end{array}$ & $\begin{array}{l}\text { Initial slow response, } \\
\text { slight operational delay }\end{array}$ & $\begin{array}{l}\text { System will not operate } \\
\text { unt il fluid temperature } \\
\text { is acceptable } \\
\end{array}$ & so & & \\
\hline & High & Hydraulic cooler failure & Process delay, fluid fire & $\begin{array}{l}\text { Hydraul ic reservoir } \\
\text { temperature sensor, atarm } \\
\text { at } 50^{\circ} \mathrm{C} \text {, no LFL, See FHE, } \\
\text { fluid } 4 \text { lash point is } \\
200^{\circ} \mathrm{C} \text {, fluid is low } \\
\text { toxcity }\end{array}$ & s1 & & \\
\hline $\begin{array}{l}\text { Temperature } \\
\text { (umbilical) }\end{array}$ & High & Electrical component fire & $\begin{array}{l}\text { Process delay, equipment } \\
\text { damage, potential } \\
\text { ignition of flammables in } \\
\text { tank }\end{array}$ & $\begin{array}{l}\text { Designed to NEC } \\
\text { standards, fuses, } \\
\text { breakers, etc., high } \\
\text { temperature components } \\
\text { (arm spec'd to } 150^{\circ} \mathrm{F} \text { ), } \\
\text { small fuel source (fire } \\
\text { load), purge air will } \\
\text { reduce potent ial for } \\
\text { entry of gas into arm. }\end{array}$ & $\begin{array}{l}\mathrm{s} 1 / \mathrm{s} 2 \\
/ \mathrm{s} 3\end{array}$ & $\begin{array}{l}\text { Propagation to tank gas } \\
\text { (S2) requires multiple } \\
\text { failures, s3 only if } \\
\text { detonation occurs }\end{array}$ & \\
\hline \multirow[t]{2}{*}{ Reaction } & $\begin{array}{l}\text { Low } \\
\text { (slow) }\end{array}$ & Corrosion & $\begin{array}{l}\text { Process delay, equipment } \\
\text { damage }\end{array}$ & $\begin{array}{l}\text { Inspection and } \\
\text { decontamination of arm } \\
\text { after each use, corrosion } \\
\text { resistant materials, } \\
\text { internals protected by } \\
\text { air purge and boots, } \\
\text { boots maintained. } \\
\end{array}$ & s1 & & \\
\hline & $\begin{array}{l}\text { Low } \\
(s ! \text { ow })\end{array}$ & Radiation exposure & $\begin{array}{l}\text { Component degradation, } \\
\text { more frequent maint. }\end{array}$ & $\begin{array}{l}\text { Arm designed to withstand } \\
1.0 \text { E05 rads, regular } \\
\text { maintainence \& boot } \\
\text { changes }\end{array}$ & $\mathbf{s} 1$ & & \\
\hline \multirow[t]{2}{*}{ Speed } & $\begin{array}{l}\text { No } \\
\text { (stopped) }\end{array}$ & $\begin{array}{l}\text { Arm snagged on in-tank } \\
\text { hardware }\end{array}$ & $\begin{array}{l}\text { Process delay, equipment } \\
\text { damage }\end{array}$ & $\begin{array}{l}\text { Cameras to aid in } \\
\text { maneuvering of arm, world } \\
\text { model of tank internats } \\
\text { for planning, arm is } \\
\text { robust, highly flexible } \\
\text { ( } 7 \text { jointed) }\end{array}$ & $\mathbf{s 1}$ & & \\
\hline & $\begin{array}{l}\text { Part of } \\
\text { (out of } \\
\text { synch) }\end{array}$ & Control systen failure & $\begin{array}{l}\text { Uncontrolled motion } \\
\text { (process delay) }\end{array}$ & $\begin{array}{l}\text { Software val idation and } \\
\text { verification, redundant } \\
\text { controls and shutdown }\end{array}$ & $\mathbf{s 1}$ & & \\
\hline
\end{tabular}


Table 8-1. NODE \#1: Light Duty Utility Arm (IDUA).

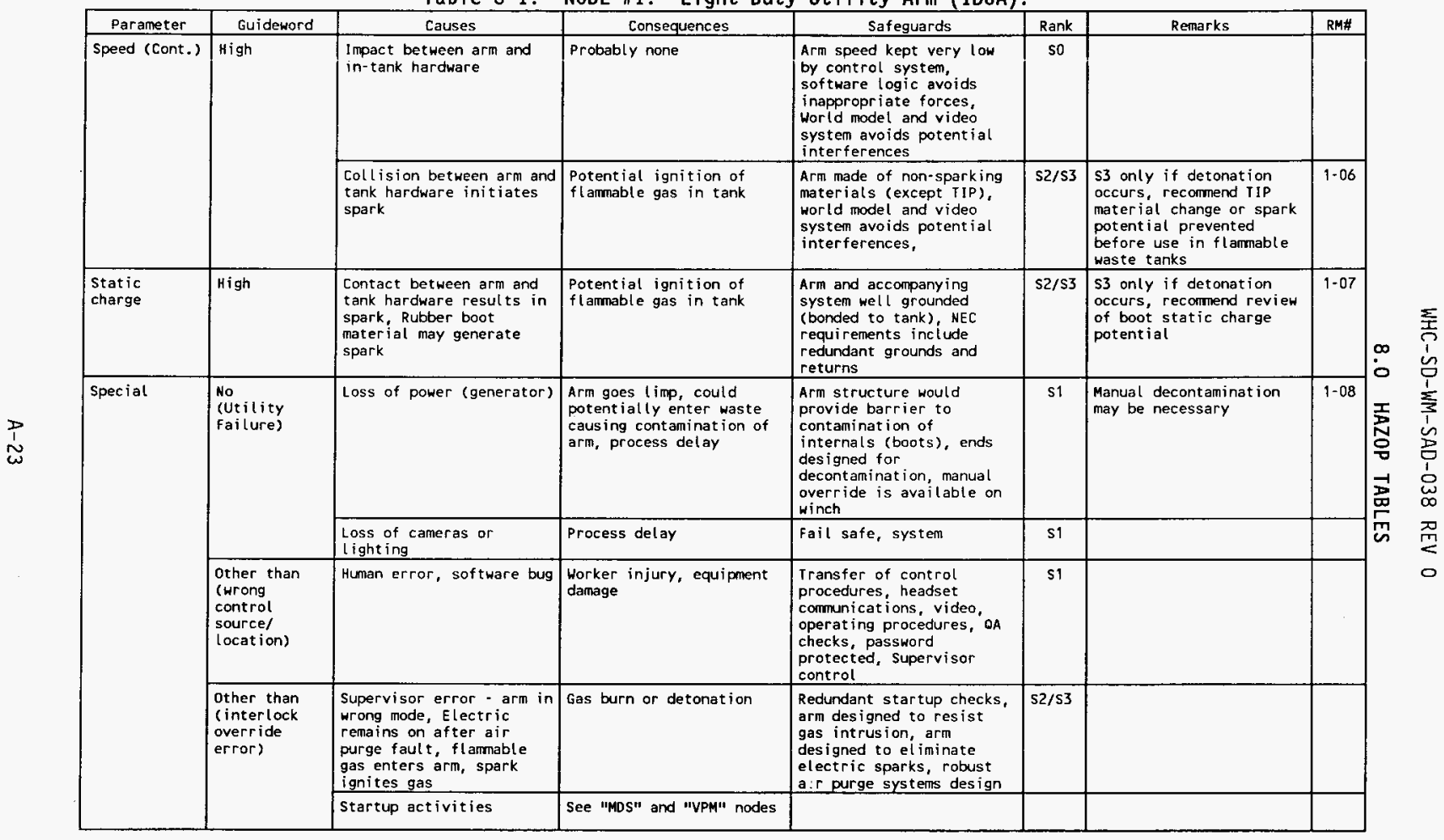


Table 8-1. NODE \#1: Light Duty Utility Arm (IDUA).

\begin{tabular}{|c|c|c|c|c|c|c|c|}
\hline Paraneter & Guideword & Causes & Consequences & Safeguards & Rank & Remarks & RM\# \\
\hline \multirow[t]{4}{*}{$\begin{array}{l}\text { Special } \\
\text { (Cont.) }\end{array}$} & $\begin{array}{l}\text { other than } \\
\text { (startup, } \\
\text { shutdown, } \\
\text { ma intenance) }\end{array}$ & LDUA contamination & $\begin{array}{l}\text { Personnel } \\
\text { exposure/contamination }\end{array}$ & $\begin{array}{l}\text { Arm designed to avoid } \\
\text { surface contamination, } \\
\text { automatic water } \\
\text { decontamination module } \\
\text { with radiation monitor, } \\
\text { all work contained in } \\
\text { TRIC to prevent } \\
\text { contamination release, } \\
\text { administrat ive controls } \\
\text { on maintenance }\end{array}$ & s1 & & \\
\hline & \multirow{3}{*}{$\begin{array}{l}\text { Other than } \\
\text { (startup, } \\
\text { shutdown, } \\
\text { maintenance) }\end{array}$} & Industrial accidents & Personnel injuries & $\begin{array}{l}\text { Training, administrative } \\
\text { controls }\end{array}$ & si & & \\
\hline & & $\begin{array}{l}\text { Arm removed from riser } \\
\text { while still in flexed } \\
\text { position }\end{array}$ & $\begin{array}{l}\text { Equipment damage, damage } \\
\text { to riser, arm, tube, } \\
\text { potential ignition and } \\
\text { dome collapse. }\end{array}$ & $\begin{array}{l}\text { Software inter locks sense } \\
\text { excessive force and } \\
\text { prevent flexed removal, } \\
\text { cameras }\end{array}$ & $\begin{array}{c}\text { s1/s2 } \\
\text { s3 }\end{array}$ & $\begin{array}{l}\text { Probability of such } \\
\text { events may be }<10^{6} \text {. } \\
\text { check FMEA of arm }\end{array}$ & $1-09$ \\
\hline & & $\begin{array}{l}\text { Maintenance on arm while } \\
\text { in horizontal position } \\
\text { (failure to correctly } \\
\text { install supports) }\end{array}$ & $\begin{array}{l}\text { Danage to equipment, } \\
\text { personnel injuries }\end{array}$ & $\begin{array}{l}\text { Procedures, } \\
\text { administrative controls }\end{array}$ & s1 & & \\
\hline
\end{tabular}




\section{PROJECT: LDUADS HAZOP}

Table 8-2. NODE \#2: Vertical Positioning Mast (VPM).

\begin{tabular}{|c|c|c|c|c|c|c|c|}
\hline Parameter & Guideword & Causes & Consequences & Safeguards & RNK & Remarks & RM\# \\
\hline \multirow[t]{7}{*}{$\begin{array}{l}\text { Flow } \\
\text { (Hydraulic) }\end{array}$} & \multirow[t]{3}{*}{ No/Low } & $\begin{array}{l}\text { No hydraul ic fluid in } \\
\text { reservoir }\end{array}$ & \multirow[t]{2}{*}{$\begin{array}{l}\text { Mast and tubes immobile, } \\
\text { potential hydraulic } \\
\text { equipment damage }\end{array}$} & \multirow{2}{*}{$\begin{array}{l}\text { Hydraulic fluid reservoir } \\
\text { sensing, one winch per } \\
\text { VPM tube, failsafe brake } \\
\text { on each winch, inner tube } \\
\text { designed to pick up outer } \\
\text { tube, winch is not back- } \\
\text { drivable, manual override } \\
\text { available } \\
\end{array}$} & \multirow[t]{2}{*}{ "s0/s1 } & & \\
\hline & & Line plug & & & & & \\
\hline & & Line break, pump failure & $\begin{array}{l}\text { Mast immobile, } \\
\text { potentially falls, } \\
\text { potential equipment and } \\
\text { tank damage, spill of } \\
\text { hydraulic fluid (process } \\
\text { delay). }\end{array}$ & $\begin{array}{l}\text { Hydraul ic fluid reservoir } \\
\text { sensing, mast brake } \\
\text { prevents falt } I \text { of mast, } \\
\text { fall direction is down to } \\
\text { base position (no } \\
\text { personnel in area), vPM } \\
\text { hydraul ic system uses } \\
\text { two-way cyl inder and has } \\
\text { pressure rel ief }\end{array}$ & $\begin{array}{c}\mathrm{s} 1 \\
\mathrm{~s} 2 / \mathrm{s} 3\end{array}$ & $\begin{array}{l}\text { Recommend check of VPM } \\
\text { hydraulic system for } \\
\text { rapid fall upon line } \\
\text { break, examine } \\
\text { slipping potential of } \\
\text { hydraut ic fluid on } \\
\text { brake pads, verify } \\
\text { maximum force does not } \\
\text { exceed dome capacity } \\
\end{array}$ & $2-01$ \\
\hline & \multirow[t]{2}{*}{ High } & Line break & See "flow" above & & & & \\
\hline & & $\begin{array}{l}\text { Hydraul ic pump/valve } \\
\text { faults, compensator stuck } \\
\text { open }\end{array}$ & $\begin{array}{l}\text { Mast tubes raised or } \\
\text { lowered too rapidly, mast } \\
\text { tubes overrun intended } \\
\text { stop point; potential for } \\
\text { free-fall } \text {; and tank bottom } \\
\text { puncture }\end{array}$ & $\begin{array}{l}\text { Top of travel limit } \\
\text { switches on each tube are } \\
\text { interlocked to winch, } \\
\text { hard stop on ends of } \\
\text { tubes limits travel (not } \\
\text { designed to survive free } \\
\text { falil, torque limiting } \\
\text { feature on winch, one } \\
\text { winch per vpm tube, } \\
\text { faitsafe brake on each } \\
\text { winch, inner tube } \\
\text { designed to pick up outer } \\
\text { tube, winch is not back- } \\
\text { drivable, manual override } \\
\text { available, umbilical } \\
\text { system is Kevlar wrapped } \\
\text { to act as impact limiter } \\
\end{array}$ & $\mathrm{s} 2 / \mathrm{s} 3$ & $\begin{array}{l}\text { Verify tank-bottom } \\
\text { puncture potential, } \\
\text { verify tank riser } \\
\text { maximum force is not } \\
\text { exceeded }\end{array}$ & $2-02$ \\
\hline & $\begin{array}{l}\text { Other than } \\
\text { (wrong } \\
\text { material) }\end{array}$ & \multicolumn{5}{|l|}{ See "LDUA" node } & \\
\hline & $\begin{array}{l}\text { Reverse } \\
\text { (bkflow) }\end{array}$ & \multicolumn{5}{|l|}{ See "LDUA" node } & \\
\hline
\end{tabular}


Table 8-2. NODE \#2: Vertical Positioning Mast (VPM).

\begin{tabular}{|c|c|c|c|c|c|c|c|}
\hline Parameter & Guideword & Causes & Consequences & Safeguards & RNK & Remarks & RM\# \\
\hline \multirow{6}{*}{$\begin{array}{l}\text { Flon (purge } \\
\text { air) }\end{array}$} & \multirow[t]{3}{*}{ No/flow } & Compressor fails & \multirow{3}{*}{$\begin{array}{l}\text { Potential for increased } \\
\text { contamination in mast, } \\
\text { increased moisture and } \\
\text { corrosion in mast } \\
\text { atmosphere }\end{array}$} & \multirow[t]{3}{*}{ See "LOUA" node } & \multirow[t]{3}{*}{ s1 } & & \\
\hline & & Line plug & & & & & \\
\hline & & Line break & & & & & \\
\hline & High & See "LDUA" node & None of significance & N/A & so & & \\
\hline & $\begin{array}{l}\text { As well as } \\
\text { impurities }\end{array}$ & \multicolumn{5}{|l|}{ See "LDUA" node } & \\
\hline & $\begin{array}{l}\text { Reverse } \\
\text { (bkflow) }\end{array}$ & None of interest & Hone of significance & & so & & \\
\hline \multirow{3}{*}{$\begin{array}{l}\text { Pressure } \\
\text { (Hydraut ic) }\end{array}$} & No/Low & \multicolumn{5}{|l|}{ See "Flow" } & \\
\hline & High & \multicolumn{5}{|l|}{ See "Flon" } & \\
\hline & $\begin{array}{l}\text { Reverse } \\
\text { (vaculm) }\end{array}$ & $\begin{array}{l}\text { Not considered possible } \\
\text { for hydraul ic systems }\end{array}$ & & & N/A & & \\
\hline \multirow{3}{*}{$\begin{array}{l}\text { Pressure } \\
\text { (air purge) }\end{array}$} & No/LOW & \multicolumn{5}{|l|}{ See "Flow" } & \\
\hline & High & \multicolumn{5}{|l|}{ See "flow" } & \\
\hline & Reverse & \multicolumn{5}{|l|}{ See "F low" } & \\
\hline \multirow[t]{4}{*}{ Temperature } & $\begin{array}{l}\text { No/low } \\
\text { (freezing) }\end{array}$ & freez ing weather & $\begin{array}{l}\text { Condensat ion buildup } \\
\text { (slightly increased } \\
\text { potential for corrosion), } \\
\text { freezing of moving parts }\end{array}$ & System designed for $-20^{\circ} \mathrm{F}$ & s1 & & \\
\hline & \multirow[t]{3}{*}{ High } & Thermal expansion & $\begin{array}{l}\text { Alignment problems } \\
\text { w/riser (could cause } \\
\text { contact with riser) }\end{array}$ & $\begin{array}{l}\text { System designed for } \\
120^{\circ} \mathrm{F} \text {, al igment can be } \\
\text { readjusted }\end{array}$ & s1 & & \\
\hline & & $\begin{array}{l}\text { Fire (range, vehicle, } \\
\text { fuel, nearby facility) }\end{array}$ & $\begin{array}{l}\text { Structure destroyed due } \\
\text { to sustained fire, } \\
\text { potential for mast or } \\
\text { LDUA to fall into tank }\end{array}$ & $\begin{array}{l}\text { VPM enclosed in aluminum } \\
\text { panels, low fire loading, } \\
\text { truck can be removed in } \\
\text { case of range fire, } \\
\text { failsafe brakes on tubes } \\
\end{array}$ & s1 & $\begin{array}{l}\text { See Fire Hazards } \\
\text { Evaluation }\end{array}$ & $\begin{array}{c}2 \\
03 \\
03\end{array}$ \\
\hline & & $\begin{array}{l}\text { High hydraulic fluid } \\
\text { temperature }\end{array}$ & \multicolumn{4}{|l|}{ See "LOUA" node } & \\
\hline
\end{tabular}


Table 8-2. NODE \#2: Vertical Positioning Mast (VPM).

\begin{tabular}{|c|c|c|c|c|c|c|c|}
\hline Parameter & Guideword & Causes & Consequences & Safeguards & RNK & Remarks & RM\# \\
\hline Reaction & Lor (slow) & $\begin{array}{l}\text { Poor decontamination, } \\
\text { caust ic waste contacts } \\
\text { arm, causes corrosion of } \\
\text { VPM }\end{array}$ & $\begin{array}{l}\text { Breaches mast casing } \\
\text { (aluminum) in extreme } \\
\text { case increas ing potential } \\
\text { for release of } \\
\text { contamination }\end{array}$ & $\begin{array}{l}\text { Limited contact of end } \\
\text { effectors (not arm) with } \\
\text { waste, decontamination } \\
\text { performed prior to } \\
\text { retraction of arm in VPM, } \\
\text { loss of purge air } \\
\text { (interlock) shuts down } \\
\text { system }\end{array}$ & s1 & & \\
\hline \multirow[t]{5}{*}{ Speed } & No/Low & \multicolumn{5}{|c|}{ See Hydraulic Flow and Pressure } & \\
\hline & \multirow[t]{3}{*}{ High } & \multirow[t]{2}{*}{$\begin{array}{l}\text { Cable break, winch } \\
\text { support breaks }\end{array}$} & $\begin{array}{l}\text { Mast tubes free fall, } \\
\text { damage } r \text { iser/tank }\end{array}$ & $\begin{array}{l}\text { Designed safety margin on } \\
\text { worst-case load is } 5: 1 \text {, } \\
\text { one winch per vPM tube, } \\
\text { failsafe brake on each } \\
\text { winch, inner tube } \\
\text { designed to pick up outer } \\
\text { tube, winch is not back- } \\
\text { drivable, manual override } \\
\text { available } \\
\end{array}$ & $\begin{array}{c}\mathrm{s} 1 \\
\mathrm{~s} 2 / \mathrm{s} 3\end{array}$ & & \\
\hline & & & $\begin{array}{l}\text { Tubes/arm inserted too } \\
\text { fast, pressurize tank }\end{array}$ & Dual HEPA filter vents & so & & \\
\hline & & $\begin{array}{l}\text { Mast wi thdrawn too } \\
\text { quickly }\end{array}$ & Probably no effect & $\begin{array}{l}\text { Maximum speed limited by } \\
\text { hydraul ics with pressure } \\
\text { relief valve, inlet and } \\
\text { outlet valve controls } \\
\end{array}$ & so & & \\
\hline & Reverse & $\begin{array}{l}\text { Mast commanded to raise } \\
\text { when ful ly withdrawn in } \\
\text { tube }\end{array}$ & $\begin{array}{l}\text { Cable/winch break, mast } \\
\text { free-fall }\end{array}$ & $\begin{array}{l}\text { Limit switch on tube } \\
\text { travel tied directly to } \\
\text { winch, sof tware limits on } \\
\text { end of travel } \\
\end{array}$ & s1 & & \\
\hline \multirow[t]{3}{*}{ Special } & \multirow[t]{2}{*}{$\begin{array}{l}\text { No (loss of } \\
\text { utility) }\end{array}$} & Loss of control & Process delay & $\begin{array}{l}\text { Brake keeps mast from } \\
\text { fall ing/sliding, see } \\
\text { safeguards in vPM } \\
\text { hydraulic flow }\end{array}$ & s1 & & \\
\hline & & Loss of computer & $\begin{array}{l}\text { Process delay (can't } \\
\text { control mast) }\end{array}$ & $\begin{array}{l}\text { Hand-crank can remove } \\
\text { mast tubes from riser }\end{array}$ & s1 & & \\
\hline & $\begin{array}{l}\text { other than } \\
\text { (startup, } \\
\text { shutdon, } \\
\text { maintenance) }\end{array}$ & $\begin{array}{l}\text { Mast tubes not } \\
\text { sufficienty } \\
\text { decontaminated prior to } \\
\text { removal }\end{array}$ & $\begin{array}{l}\text { Increased exposure to } \\
\text { maintenance personnel }\end{array}$ & $\begin{array}{l}\text { Administrative controls } \\
\text { on contamination, } \\
\text { radiation monitors in } \\
\text { decontamination module, } \\
\text { contamination contained } \\
\text { within IRIC, backup } \\
\text { decontamination system } \\
\text { available } \\
\end{array}$ & si & & \\
\hline
\end{tabular}


Table 8-2. NODE \#2: Vertical Positioning Mast (VPM).

\begin{tabular}{|c|c|c|c|c|c|c|c|}
\hline Parameter & Guideword & Causes & Consequences & Safeguards & RNK & Remarks & RM\#\# \\
\hline \multirow[t]{3}{*}{$\begin{array}{l}\text { Special } \\
\text { (Cont.) }\end{array}$} & \multirow[t]{3}{*}{$\begin{array}{l}\text { Other than } \\
\text { (startup, } \\
\text { shutdown, } \\
\text { maintenance) }\end{array}$} & $\begin{array}{l}\text { Isolation valves close on } \\
\text { arm or do not open during } \\
\text { installation }\end{array}$ & Equipment damage & $\begin{array}{l}\text { Sof tware inter locks } \\
\text { prevent valve from } \\
\text { closing on arm and } \\
\text { prevent arm movement if } \\
\text { valve closed, } \\
\text { administrative controls } \\
\text { (procedures) }\end{array}$ & $\mathbf{s 1}$ & & \\
\hline & & $\begin{array}{l}\text { Industrial hazards during } \\
\text { maintenance }\end{array}$ & Personnel injuries & Training, procedures & s1 & & \\
\hline & & $\begin{array}{l}\text { Failure to correctly } \\
\text { install supports on arm } \\
\text { while in horizontal } \\
\text { maintenance position }\end{array}$ & $\begin{array}{l}\text { Maintenance worker } \\
\text { injury, damage to arm, } \\
\text { mission delay }\end{array}$ & $\begin{array}{l}\text { Maintain procedures, } \\
\text { training, health and } \\
\text { safety plan }\end{array}$ & $\$ 1$ & & \\
\hline
\end{tabular}




\section{PROJECT: LDUADS HAZOP}

Table 8-3. NODE \#3: Mobile Deployment System.

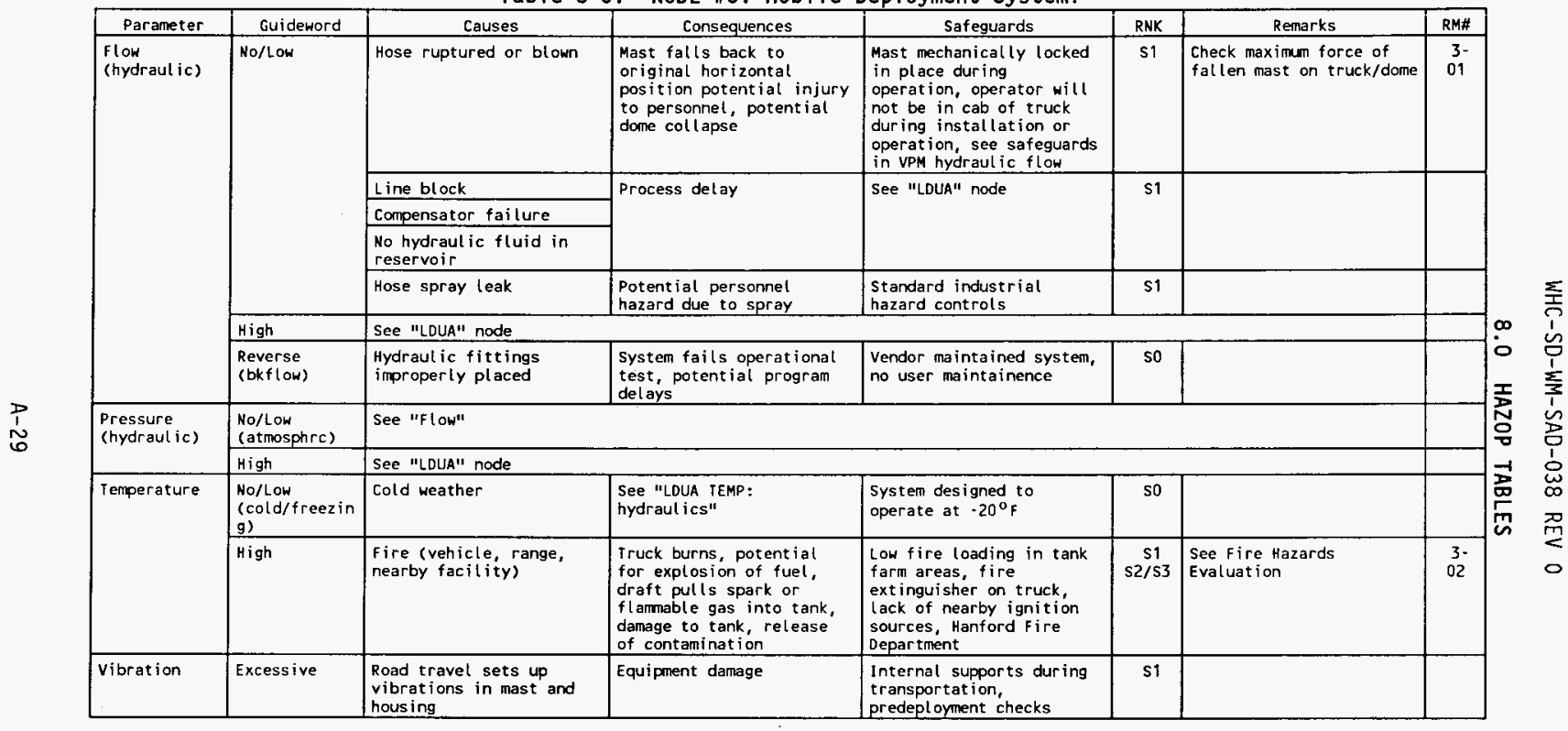


Table 8-3. NODE \#3: Mobile Deployment System.

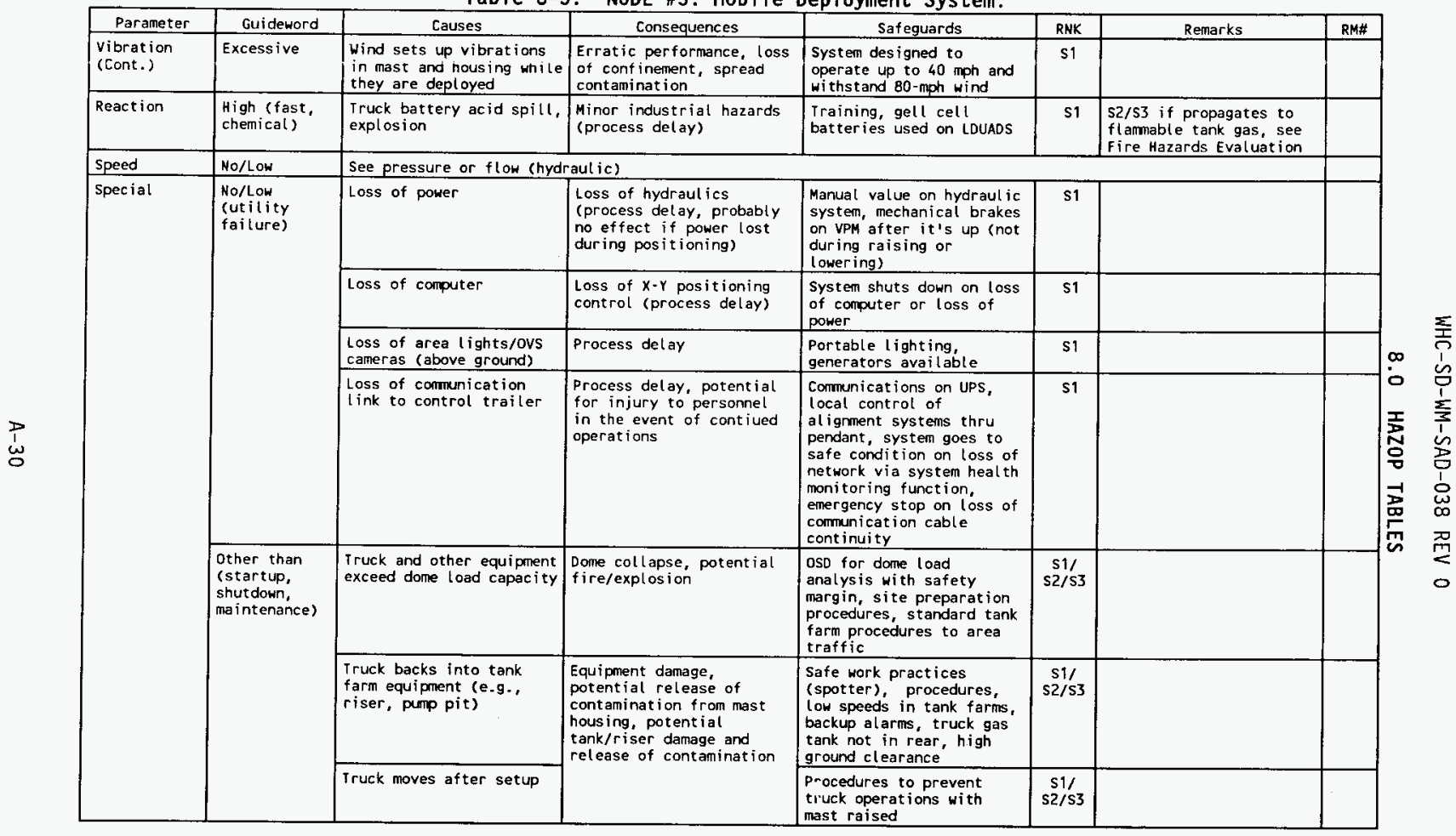


Table 8-3. NODE \#3: Mobile Deployment System.

\begin{tabular}{|c|c|c|c|c|c|c|c|}
\hline Parameter & Guideword & Causes & Consequences & Safeguards & RNK & Remarks & RM\# \\
\hline \multirow[t]{8}{*}{$\begin{array}{l}\text { Special } \\
\text { (Cont.) }\end{array}$} & \multirow[t]{8}{*}{$\begin{array}{l}\text { Other than } \\
\text { (startup, } \\
\text { shutdown, } \\
\text { maintenance) }\end{array}$} & $\begin{array}{l}\text { Vehicle accident during } \\
\text { transport }\end{array}$ & $\begin{array}{l}\text { Equipment damage, } \\
\text { potential injury/death, } \\
\text { potential for minor } \\
\text { contamination release }\end{array}$ & Oriver training & s1 & & \\
\hline & & Vehicte engine fire & $\begin{array}{l}\text { See temperature in VPM } \\
\text { node }\end{array}$ & & & & \\
\hline & & $\begin{array}{l}\text { Failure to deploy } \\
\text { outriggers or premature } \\
\text { retraction of outriggers } \\
\end{array}$ & \multirow{2}{*}{$\begin{array}{l}\text { Truck tips over, } \\
\text { increased potent ial to } \\
\text { scrape/ jam arm in riser, } \\
\text { damage tank, and release } \\
\text { contamination }\end{array}$} & \multirow[t]{2}{*}{$\begin{array}{l}\text { Administrative controls, } \\
\text { procedures, VPM position } \\
\text { indicators' (incl inometer) }\end{array}$} & \multirow[t]{2}{*}{$\begin{array}{c}s 1 / \\
s 2 / s 3\end{array}$} & & \\
\hline & & $\begin{array}{l}\text { Failure to verify } 10 \% \\
\text { load on tires }\end{array}$ & & & & & \\
\hline & & $\begin{array}{l}\text { Misaligning during } \\
\text { insertion }\end{array}$ & $\begin{array}{l}\text { Scraping/ jamming of mast } \\
\text { and arm, IIP can generate } \\
\text { spark }\end{array}$ & $\begin{array}{l}\text { Al ignment gauges used for } \\
\text { verification before LOUA } \\
\text { deployed, OAS used for } \\
\text { initial insertion, } \\
\text { procedures, training } \\
\end{array}$ & si & $\begin{array}{l}\text { TIP is titanium - spark } \\
\text { potential must be } \\
\text { resolved before use in } \\
\text { flamable tanks }\end{array}$ & \\
\hline & & $\begin{array}{l}\text { Lowering VPM to } \\
\text { horizontal while arm is } \\
\text { in riser }\end{array}$ & $\begin{array}{l}\text { Damage to mast, arm, and } \\
\text { riser, } \\
\text { Process delay }\end{array}$ & $\begin{array}{l}\text { Procedures, } \\
\text { administrative controls, } \\
\text { sof tware interlock is } \\
\text { planned, switch prevents } \\
\text { vPM movement before valve } \\
\text { closed }\end{array}$ & $\begin{array}{c}\text { s1/ } \\
\text { s2/s3 }\end{array}$ & & $3-03$ \\
\hline & & $\begin{array}{l}\text { Flat tire before or after } \\
\text { outrigger is retracted }\end{array}$ & $\begin{array}{l}\text { Missalignment of mast, } \\
\text { Process delay }\end{array}$ & $\begin{array}{l}\text { Tires maintain } 10 \% \text { of } \\
\text { load during operation so } \\
\text { flat would be noticed, } \\
\text { mast is horizontal } \\
\text { (stowed) prior to } \\
\text { retracting outriggers, } \\
\text { incl inometers on mast } \\
\end{array}$ & so/s1 & & \\
\hline & & $\begin{array}{l}\text { VPM raised into power } \\
\text { line }\end{array}$ & $\begin{array}{l}\text { Electrocution of } \\
\text { personnel }\end{array}$ & $\begin{array}{l}\text { Ho power lines near the } \\
\text { intended tank farm } \\
\text { deployment area, } \\
\text { procedures, work control }\end{array}$ & s1 & & \\
\hline $\begin{array}{l}\text { External } \\
\text { forces }\end{array}$ & High & High winds & $\begin{array}{l}\text { Mast contact with riser, } \\
\text { Resonance oscillations of } \\
\text { mast and arm, Damage to } \\
\text { TRIC, Spread } \\
\text { contamination, } \\
\text { Truck tips over (mast, } \\
\text { riser damage) }\end{array}$ & $\begin{array}{l}40 \text {-mph operating } \\
\text { restriction on LDUA } \\
\text { system and } 80 \text {-mph with no } \\
\text { damage (by design), } \\
\text { outriggers provide } \\
\text { stability }\end{array}$ & $\begin{array}{c}\$ 1 / \\
\$ 2 / \mathrm{s} 3\end{array}$ & & \\
\hline & & Seismic event & $\begin{array}{l}\text { Mast contact with riser, } \\
\text { Resonance oscillations of } \\
\text { mast and arm }\end{array}$ & $\begin{array}{l}\text { MDS designed to Hanford } \\
\text { aBE, outriggers provide } \\
\text { stability in DBE }\end{array}$ & $\begin{aligned} s 1 / \\
s 2 / 53\end{aligned}$ & & \\
\hline
\end{tabular}


WHC-SD-WM-SAD-038 REV 0

8.0 HAZOP TABLES

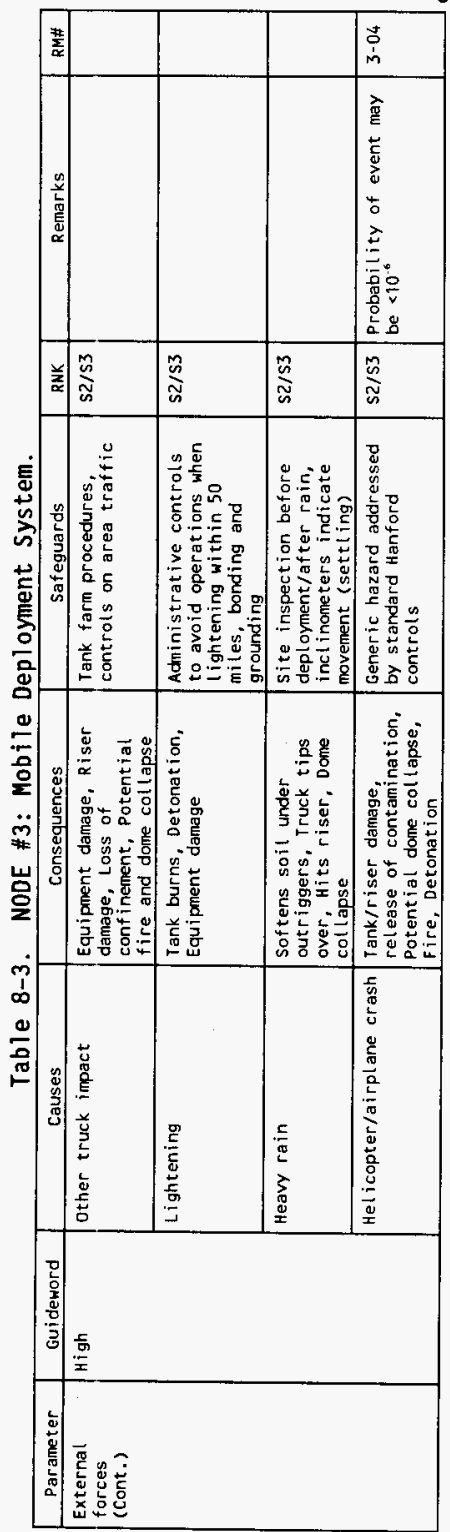


WHC-SD-WM-SAD-038 REV 0

8.0 HAZOP TABLES

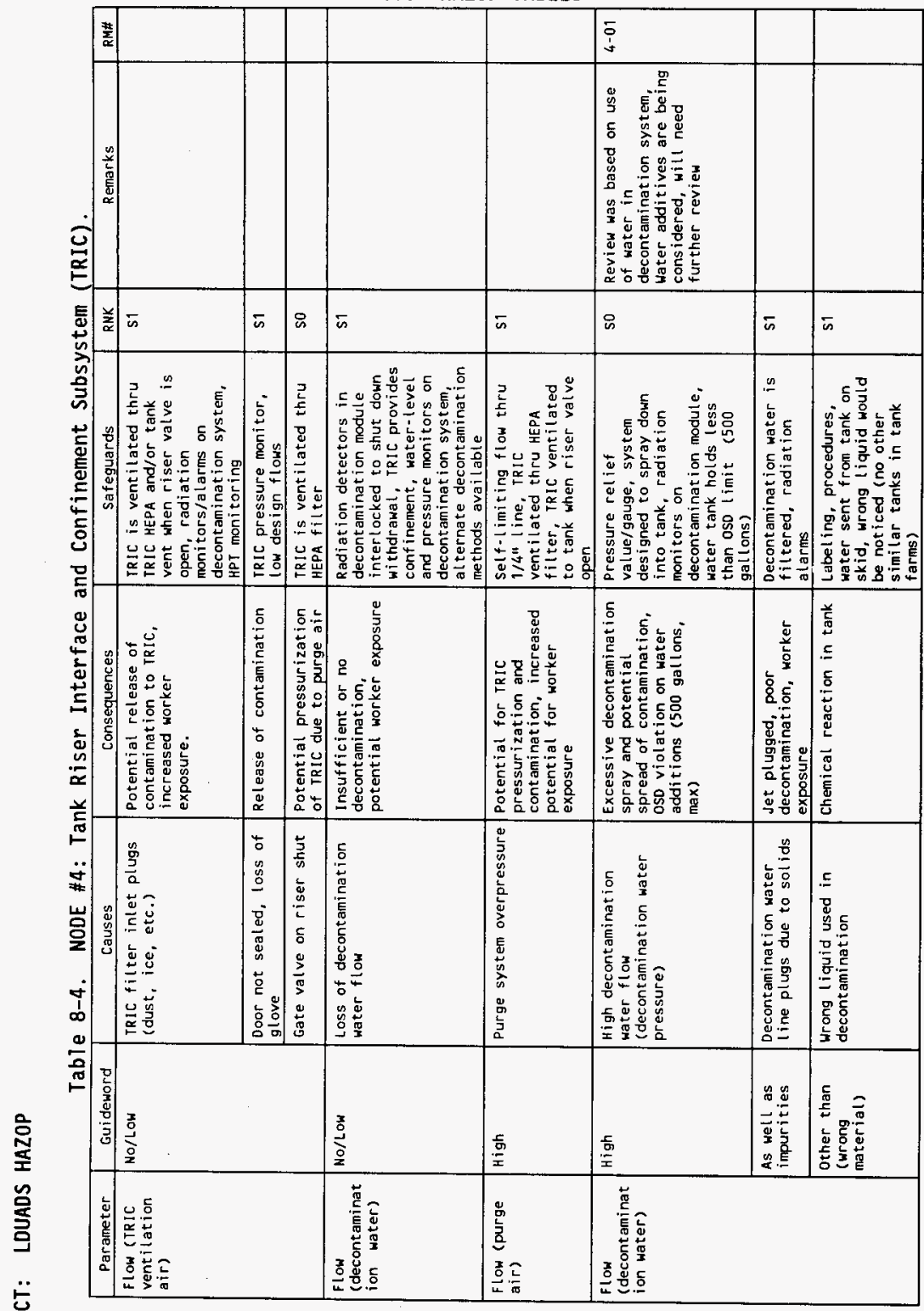


Table 8-4. NODE \#4: Tank Riser Interface and Confinement Subsystem (TRIC).

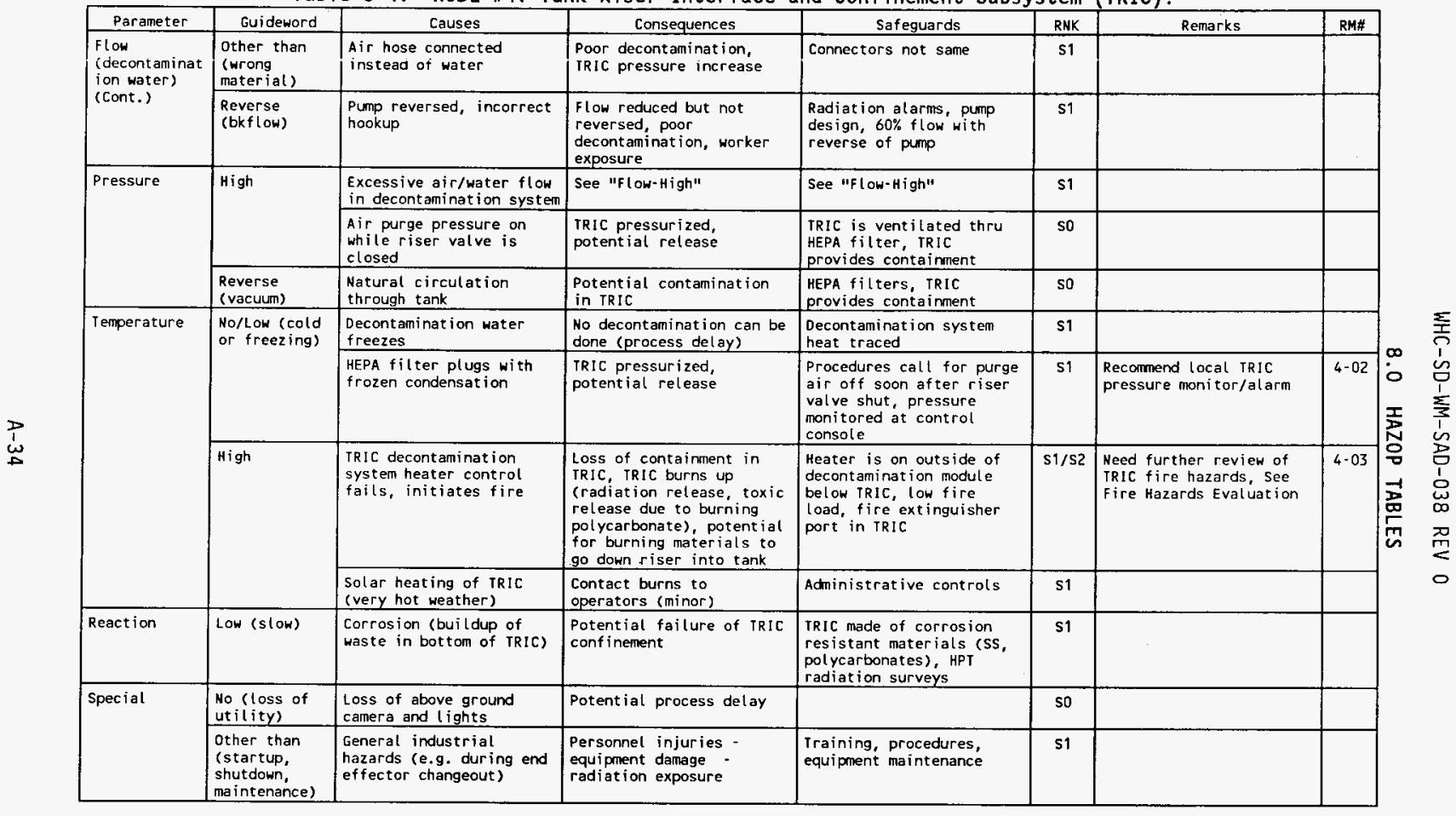


Table 8-4. NODE \#4: Tank Riser Interface and Confinement Subsystem (TRIC).

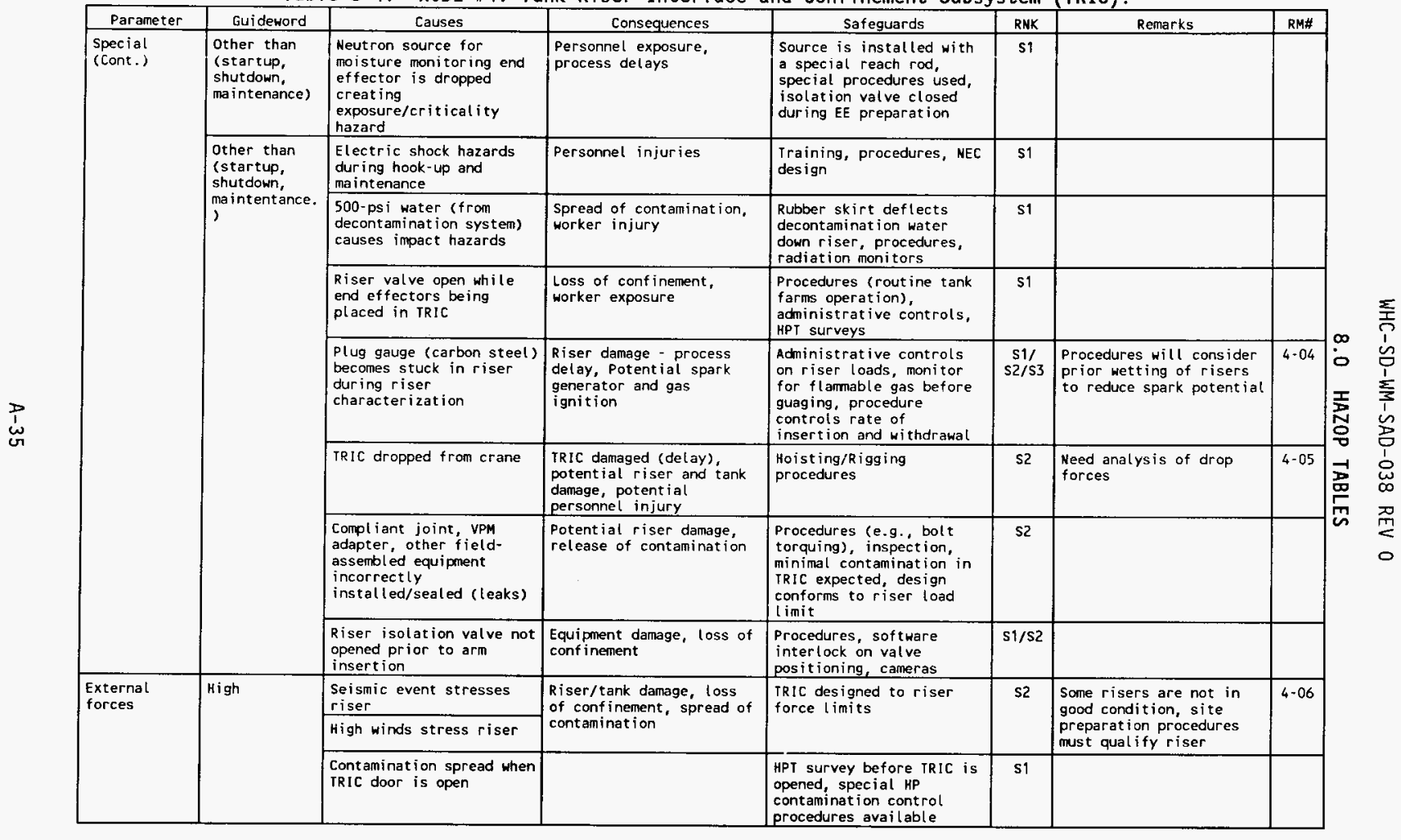




\section{PROJECT: LDUADS HAZOP}

Table 8-5. NODE \#5: Control System.

\begin{tabular}{|c|c|c|c|c|c|c|c|}
\hline Parameter & Guideword & Causes & Consequences & Safeguards & RNK & Remarks & RM\# \\
\hline \multirow[t]{4}{*}{ Temperature } & $\begin{array}{l}\text { No/Low (cold, } \\
\text { freezing) }\end{array}$ & Very cold weather & $\begin{array}{l}\text { System fails to operate } \\
\text { (dead or error), spurious } \\
\text { or wrong signals, } \\
\text { unpredictable operation } \\
\text { of system }\end{array}$ & \multirow{2}{*}{$\begin{array}{l}\text { System designed to } \\
\text { operate at } 20^{\circ} \text { to } 120^{\circ} \mathrm{F} \text {, } \\
\text { el ectronic equipment } \\
\text { failures for high/low } \\
\text { temperature are expected } \\
\text { to cause system shutdown, } \\
\text { not spurious signals, all } \\
\text { sensitive electronics in } \\
\text { conditioned enclosure, } \\
\text { diversity, redundancy in } \\
\text { hardware and software } \\
\text { with error-checking } \\
\text { routines } \\
\end{array}$} & s1 & & \\
\hline & \multirow[t]{3}{*}{ High } & Hot weather & $\begin{array}{l}\text { Drift in analog signal, } \\
\text { eventual system failure, } \\
\text { potential spurious or } \\
\text { wrong signals, } \\
\text { unpredictable operation } \\
\text { of system } \\
\end{array}$ & & s1 & & \\
\hline & & $\begin{array}{l}\text { Enclosure heater } \\
\text { overheats }\end{array}$ & $\begin{array}{l}\text { Unpredictable operation } \\
\text { of systen }\end{array}$ & $\begin{array}{l}\text { Heater controlled by } \\
\text { local thermostat; } \\
\text { automatic air } \\
\text { conditioning (cooling) } \\
\text { initiated on high } \\
\text { temperature signal; } \\
\text { diversity, redundancy in } \\
\text { hardware and software } \\
\text { with error-checking } \\
\text { routines } \\
\end{array}$ & $\mathbf{s 1}$ & & \\
\hline & & Electrical fire & $\begin{array}{l}\text { System damage, process } \\
\text { delay, potential } \\
\text { fire/smoke injuries, } \\
\text { potential enbers from } \\
\text { ATIE fire drawn into tank }\end{array}$ & $\begin{array}{l}\text { No contamination present, } \\
\text { components sealed in } \\
\text { steel cases, current- } \\
\text { limiting fuses, breakers, } \\
\text { transistors in system, } \\
\text { ATlE has high temperature } \\
\text { shut down, fire } \\
\text { ext inguisher present, } \\
\text { Hanford fire department } \\
\text { available, filters on } \\
\text { tank risers }\end{array}$ & $\begin{array}{c}\text { s1/s2 } \\
\text { s3 }\end{array}$ & $\begin{array}{l}\text { See Fire Hazards } \\
\text { Evaluation }\end{array}$ & 5-01 \\
\hline \multirow[t]{2}{*}{$\begin{array}{l}\text { Special } \\
\text { (electronic } \\
\text { signal) }\end{array}$} & \multirow[t]{2}{*}{ No } & $\begin{array}{l}\text { Inadvertent cable } \\
\text { disconnection (operator } \\
\text { error) }\end{array}$ & $\begin{array}{l}\text { System shutdown, loss of } \\
\text { data }\end{array}$ & $\begin{array}{l}\text { System goes to safe } \\
\text { shutdown on loss of } \\
\text { signal; "no signal" seen } \\
\text { as error, procedures, } \\
\text { work controls } \\
\end{array}$ & so & & \\
\hline & & $\begin{array}{l}\text { Impact, severing of cable } \\
\text { by heavy equipment }\end{array}$ & $\begin{array}{l}\text { Potential arcing, shock } \\
\text { hazard }\end{array}$ & $\begin{array}{l}\text { Type G (robust) cables } \\
\text { used at vulnerable } \\
\text { locat ions, cableway } \\
\text { protected at traffic } \\
\text { areas }\end{array}$ & s1 & & \\
\hline
\end{tabular}


Table 8-5. NODE \#5: Control System.

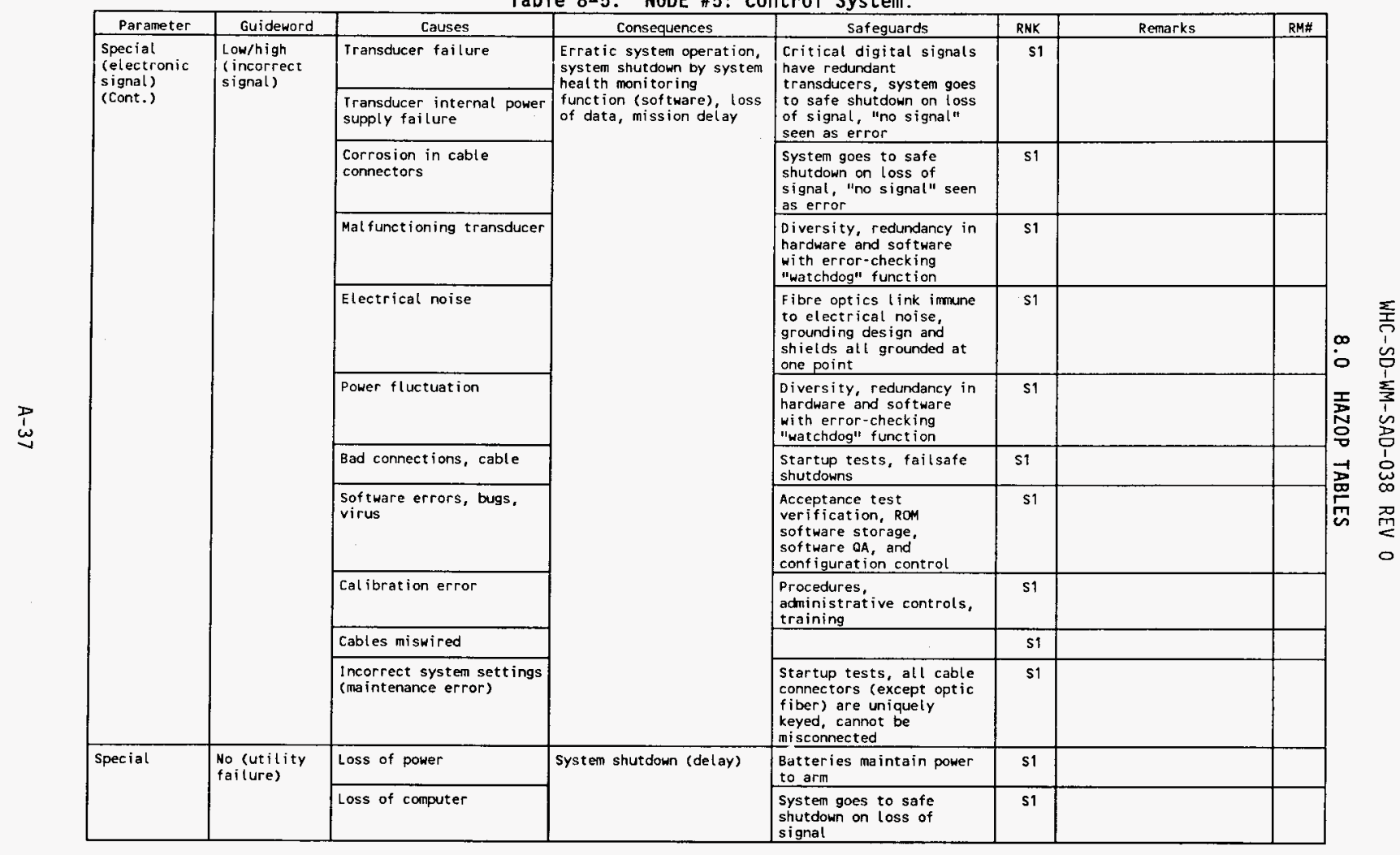


Table 8-5. NODE \#5: Control System.

\begin{tabular}{|c|c|c|c|c|c|c|c|}
\hline Parameter & Guideword & Causes & Conseguences & Safeguards & RNK & Renarks & RM\# \\
\hline \multirow[t]{11}{*}{$\begin{array}{l}\text { Special } \\
\text { (Cont.) }\end{array}$} & $\begin{array}{l}\text { No (utility } \\
\text { fatiure) }\end{array}$ & $\begin{array}{l}\text { Loss of internal power } \\
\text { suppl ies in controi } \\
\text { systems }\end{array}$ & System shutdown (delay) & $\begin{array}{l}\text { Critical digital signals } \\
\text { have redundant } \\
\text { transducers }\end{array}$ & si & & \\
\hline & & $\begin{array}{l}\text { Loss of lighting/cameras } \\
\text { (on arms) }\end{array}$ & Process delay & $\begin{array}{l}\text { Redundant lights and } \\
\text { cameras in tank }\end{array}$ & s1 & & \\
\hline & $\begin{array}{l}\text { Wrong } \\
\text { (signal) }\end{array}$ & $\begin{array}{l}\text { Wrong setting on safety } \\
\text { interlock for electric } \\
\text { shutdown on loss of purge } \\
\text { air }\end{array}$ & $\begin{array}{l}\text { Electric in arm after } \\
\text { loss of purge air, } \\
\text { potent ial ignition } \\
\text { source, flamable gas } \\
\text { burn/detonation }\end{array}$ & $\begin{array}{l}\text { Interlock switch is } \\
\text { supervisor-controlled, } \\
\text { password-protected, } \\
\text { verified by procedures, } \\
\text { manual electric shutdown } \\
\text { available } \\
\end{array}$ & $\mathrm{s} 2 / \mathrm{s} 3$ & & \\
\hline & & $\begin{array}{l}\text { Calibration error on } \\
\text { pressure transducers used } \\
\text { for safety interlock }\end{array}$ & & $\begin{array}{l}\text { Interlock operational } \\
\text { check, redundant } \\
\text { transducers, manual } \\
\text { electric shutdown } \\
\text { available } \\
\end{array}$ & $\mathrm{s} 2 / \mathrm{s} 3$ & & \\
\hline & & $\begin{array}{l}\text { Software error, wiring } \\
\text { error, mal function of } \\
\text { electronic components }\end{array}$ & $\begin{array}{l}\text { Incorrect movement of arm } \\
\text { results in tank damage, } \\
\text { potentiat fire, release } \\
\text { to air or ground }\end{array}$ & $\begin{array}{l}\text { Software QA and } \\
\text { acceptance tests. } \\
\text { Failsafe shutdown logic } \\
\text { on all operational } \\
\text { checks. }\end{array}$ & $\$ 2 / \$ 3$ & & \\
\hline & \multirow[t]{3}{*}{$\begin{array}{l}\text { Other than } \\
\text { (wrong power } \\
\text { source) }\end{array}$} & High/Low voltage & $\begin{array}{l}\text { System shutdown (delay), } \\
\text { potential equipment } \\
\text { damage }\end{array}$ & $\begin{array}{l}\text { Unique cable connectors, } \\
\text { circuit breaker } \\
\text { protected, vol tage checks } \\
\text { on oCT input }\end{array}$ & \$1 & & \\
\hline & & Wrong phase rotation & Equipment damage & \multirow{2}{*}{$\begin{array}{l}\text { Procedures require phase } \\
\text { rotation checks, } \\
\text { frequency checks on oct } \\
\text { input }\end{array}$} & s1 & & \\
\hline & & $\begin{array}{l}\text { High/Low frequency ( } A C \\
\text { current) }\end{array}$ & Motors may overspeed & & $\mathbf{s 1}$ & & \\
\hline & \multirow[t]{3}{*}{$\begin{array}{l}\text { Other than } \\
\text { (startup, } \\
\text { shutdown, } \\
\text { maint.) }\end{array}$} & $\begin{array}{l}\text { Communication failure } \\
\text { between control locations } \\
\text { and TRIC during } \\
\text { maintenance }\end{array}$ & $\begin{array}{l}\text { Potential for industriat } \\
\text { injury to personnel at } \\
\text { tank because of remote } \\
\text { operation }\end{array}$ & $\begin{array}{l}\text { Transfer of control } \\
\text { procedures, local } \\
\text { emergency stop, local } \\
\text { control through pendant } \\
\text { has priority over remote } \\
\text { control, poc protocol } \\
\text { requires giving up local } \\
\text { control intentionally, } \\
\text { cameras and radio links } \\
\end{array}$ & s1 & & \\
\hline & & $\begin{array}{l}\text { Lifting injuries in } \\
\text { moving heavy cable }\end{array}$ & \multirow[t]{2}{*}{ Personnel injuries } & \multirow[t]{2}{*}{$\begin{array}{l}\text { Training, procedures, } \\
\text { administrat ive controls }\end{array}$} & \multirow[t]{2}{*}{ s1 } & & \\
\hline & & Electrical shock hazards & & & & & \\
\hline
\end{tabular}




\section{PROJECT: LDUADS HAZOP}

Table 8-6. NODE \#6: Operations Control Trailer.

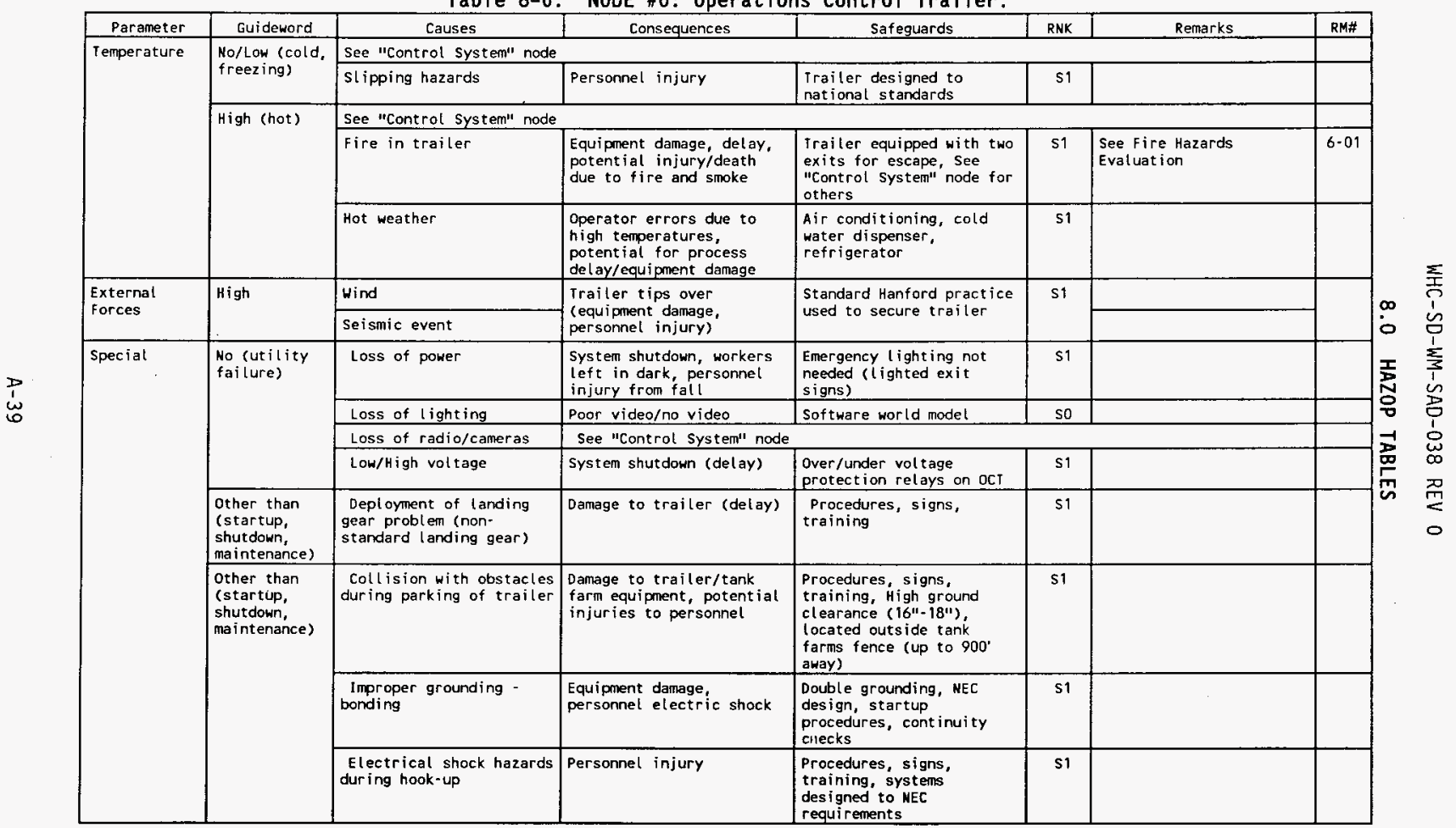




\section{PROJECT: LDUADS HAZOP}

Table 8-7. NODE \#7: End Effectors.

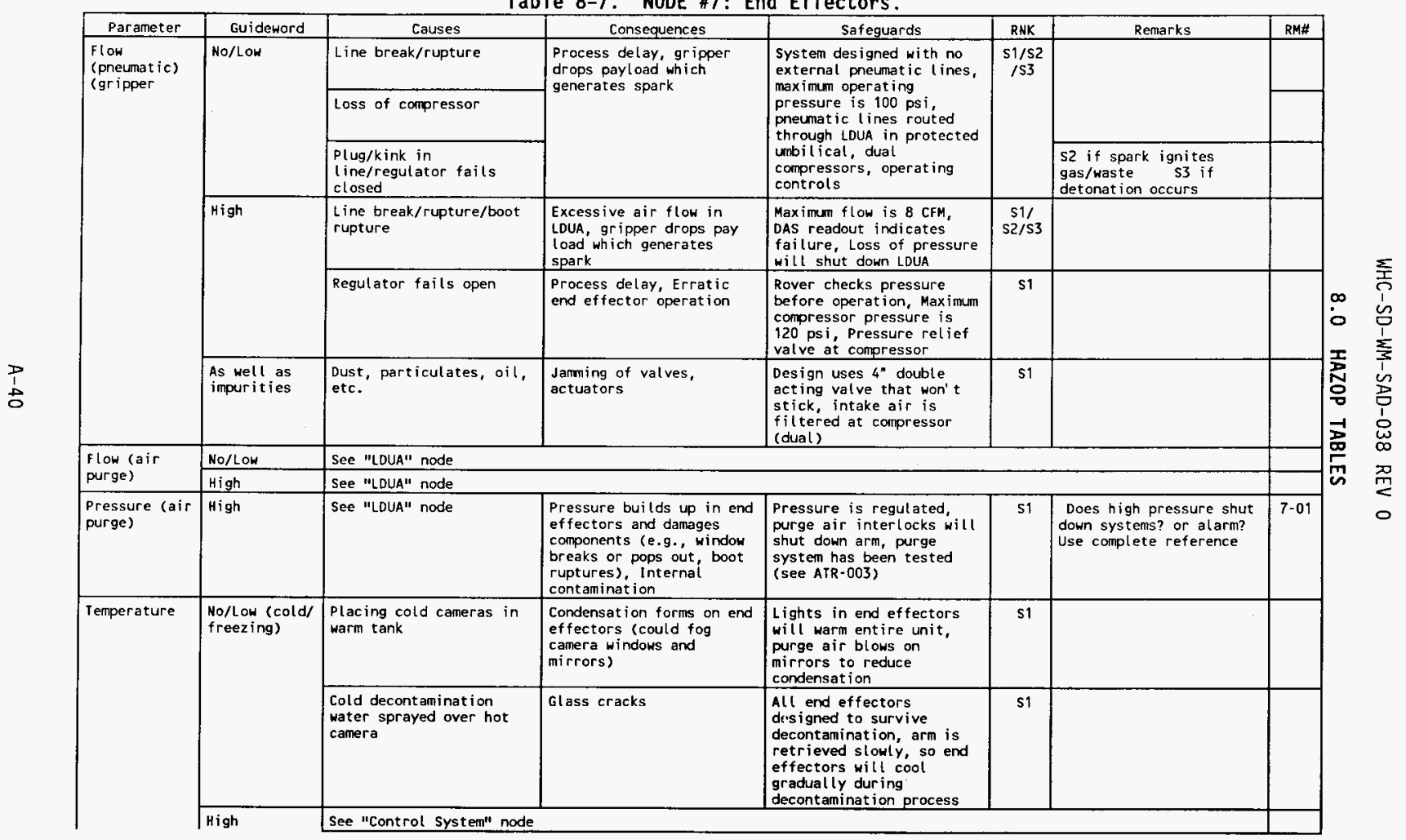


Table 8-7. NODE \#7: End Effectors.

\begin{tabular}{|c|c|c|c|c|c|c|c|}
\hline \multirow[t]{2}{*}{ Parameter } & \multirow[t]{2}{*}{ Guideword } & Causes & Consequences & Safeguards & RNK & Remarks & RM\# \\
\hline & & $\begin{array}{l}\text { Contact or close } \\
\text { proximity to thermally } \\
\text { hot waste }\end{array}$ & $\begin{array}{l}\text { Equipment failure/damage, } \\
\text { Process delay }\end{array}$ & $\begin{array}{l}\text { End effectors designed to } \\
\text { operate at } 150^{\circ} \mathrm{F} \text {. } \\
\text { administrative controls } \\
\text { prevent ing close exposure } \\
\text { to hot areas }\end{array}$ & s1 & & \\
\hline \multirow[t]{2}{*}{$\begin{array}{l}\text { Temperature } \\
\text { (Cont.) }\end{array}$} & & $\begin{array}{l}\text { Fire (electrical, } \\
\text { lighting) }\end{array}$ & $\begin{array}{l}\text { Potential ignition of } \\
\text { flammables in tank, } \\
\text { conf inement failure, } \\
\text { release }\end{array}$ & $\begin{array}{l}\text { Air purge, end effectors } \\
\text { contained in housing }\end{array}$ & $\begin{array}{ll}s 21 \\
\text { s3 }\end{array}$ & $\begin{array}{l}\text { See Fire Hazards } \\
\text { Evaluation, s3 only if } \\
\text { atmosphere is detonable }\end{array}$ & $\begin{array}{r}7- \\
02 \\
\end{array}$ \\
\hline & & $\begin{array}{l}\text { fire (ignition of } \\
\text { gas/waste by laser } \\
\text { heat ing of aerosol } \\
\text { particle or volatile } \\
\text { waste) }\end{array}$ & $\begin{array}{l}\text { Potential ignition of } \\
\text { flammables in tank, } \\
\text { confinement fai lure, } \\
\text { release }\end{array}$ & $\begin{array}{l}\text { OAS lasers are class } 3 \mathrm{~A} \\
\text { low energy and low } \\
\text { potent ial for heat ing, } \\
\text { Bureau of Mines study is } \\
\text { underway }\end{array}$ & $\$ 2 / 53$ & $\begin{array}{l}\text { Review site Bureau of } \\
\text { Mines study, resolve } \\
\text { issue on laser ignition }\end{array}$ & $7-03$ \\
\hline \multirow[t]{2}{*}{ Reaction } & \multirow[t]{2}{*}{ Low (slow) } & \begin{tabular}{|l}
$</$ spctable> \\
$</ \mathrm{spc}>$ \\
Corrosion \\
\end{tabular} & \multicolumn{4}{|l|}{ See "LDUA" node } & \\
\hline & & Radiation exposure & $\begin{array}{l}\text { Component degradation, } \\
\text { more frequent maintenance }\end{array}$ & $\begin{array}{l}\text { All on-arm end effectors } \\
\text { designed for } 10^{\circ} \text { rad, } \\
\text { modular des ign al lows } \\
\text { easy maintenance and } \\
\text { replacement. } \\
\end{array}$ & s1 & & \\
\hline \multirow[t]{2}{*}{ Special } & \multirow{2}{*}{$\begin{array}{l}\text { No (utility } \\
\text { failure) } \\
\text { other than } \\
\text { (startup, } \\
\text { shutdown, } \\
\text { maintenance) }\end{array}$} & \multicolumn{5}{|l|}{ See "LDUA" node } & \\
\hline & & $\begin{array}{l}\text { End effector not at tached } \\
\text { correctly }\end{array}$ & $\begin{array}{l}\text { Loss of utility sources } \\
\text { (air, electricity, etc.), } \\
\text { end effector falls off } \\
\text { (possibly into waste), } \\
\text { aluminum exposed to tank } \\
\text { waste, ignition and burn } \\
\text { or detonation. }\end{array}$ & $\begin{array}{l}\text { Positive engagement } \\
\text { indicat ion ( } 3 \text { independent } \\
\text { positive engagement } \\
\text { pins), operator training, } \\
\text { purge air di lutes gas, } \\
\text { slow reaction. }\end{array}$ & $\begin{array}{l}51 / \\
52 / 53\end{array}$ & $\begin{array}{l}\text { Verify positive } \\
\text { engagement sensing prior } \\
\text { to tank entry, consider } \\
\text { coat ing/replacing } \\
\text { al uminum. }\end{array}$ & $7 \cdot 04$ \\
\hline Special & $\begin{array}{l}\text { Other than } \\
\text { (startup, } \\
\text { shutdown, } \\
\text { maintenance) }\end{array}$ & $\begin{array}{l}\text { Non-arm end effectors } \\
\text { (ovs, osvs) dropped down } \\
\text { riser }\end{array}$ & $\begin{array}{l}\text { Loss of equipment, tank } \\
\text { penetration, leak to } \\
\text { soil, potential ignition }\end{array}$ & $\begin{array}{l}\text { Safety wire on end } \\
\text { effectors, umbilical } \\
\text { restrains the fall, } \\
\text { procedures and work } \\
\text { controls }\end{array}$ & $\begin{array}{l}51 / 52 \\
/ 53\end{array}$ & & \\
\hline
\end{tabular}




\section{DISTRIBUTION SHEET}

\begin{tabular}{|c|c|c|c|c|c|}
\hline \multirow{2}{*}{$\begin{array}{l}\text { To } \\
\text { Distribution }\end{array}$} & \multirow{2}{*}{\multicolumn{3}{|c|}{$\begin{array}{l}\text { From } \\
\text { TWRS SAR Engineering }\end{array}$}} & \multicolumn{2}{|l|}{ Page 1 of 1} \\
\hline & & & & \multicolumn{2}{|c|}{ Date $6 / 27 / 96$} \\
\hline \multicolumn{4}{|c|}{ Project Title/Work Order } & \multicolumn{2}{|c|}{ EDT No. 614544} \\
\hline \multicolumn{4}{|c|}{$\begin{array}{l}\text { Safety Assessment for Hot Test of Light Duty Utility Arm in } \\
\text { Hanford Tank 241-T-106 }\end{array}$} & ECN No. N/ & \\
\hline Name & MSIN & $\begin{array}{c}\text { Text } \\
\text { With All } \\
\text { Attach. }\end{array}$ & Text Only & $\begin{array}{l}\text { Attach./ } \\
\text { Appendix } \\
\text { Only }\end{array}$ & $\begin{array}{l}\text { EDT/ECN } \\
\text { Only }\end{array}$ \\
\hline $\begin{array}{l}\text { J. J. Badden } \\
\text { K. L. Bennett (5) } \\
\text { R. J. Blanchard } \\
\text { R. K. Brown } \\
\text { J. G. Burton } \\
\text { R. B. Conrad (2) } \\
\text { W. L. Cowley } \\
\text { D. B. Engelman } \\
\text { E. C. Heubach II (10) } \\
\text { J. P. Hinckley/LATA, Inc. (2) } \\
\text { R. A. Huckfeldt } \\
\text { L. S. Krogsrud } \\
\text { M. N. Islam } \\
\text { W. L. Jaquish } \\
\text { G. R. Kiebel } \\
\text { J. J. Klos } \\
\text { T. C. Mackey } \\
\text { M. L. McElroy } \\
\text { D. P. Niebuhr } \\
\text { D. H. Shuford } \\
\text { S. M. Stahl } \\
\text { R. G. Stickney } \\
\text { J. E. Truax }\end{array}$ & $\begin{array}{l}\text { T4-07 } \\
\text { N1-21 } \\
\text { S7-12 } \\
H 5-68 \\
\text { S7-01 } \\
H 5-09 \\
\text { A3-37 } \\
\text { L6-37 } \\
\text { A3-37 } \\
\text { B1-44 } \\
\text { R3-01 } \\
\text { T4-07 } \\
\text { R3-08 } \\
\text { K5-22 } \\
\text { N1-21 } \\
\text { R2-54 } \\
\text { S2-03 } \\
\text { S7-07 } \\
\text { S7-03 } \\
\text { S7-01 } \\
\text { A3-37 } \\
\text { B1- } 12 \\
\text { R2-50 }\end{array}$ & $\begin{array}{l}x \\
x \\
x \\
x \\
x \\
x \\
x \\
x \\
x \\
x \\
x \\
x \\
x \\
x \\
x \\
x \\
x \\
x \\
x \\
x \\
x \\
x \\
x \\
x \\
x \\
x\end{array}$ & $\cdot$ & & \\
\hline Central Files (2) & A3-88 & $x$ & & & \\
\hline
\end{tabular}

